\title{
An Empirical Study of AAA Consumer Arbitrations
}

\author{
CHRISTOPHER R. DRAHOZAL* AND SAMANTHA ZYONTZ**
}

\section{INTRODUCTION}

Empirical research has become a central focus of the policy debate over consumer and employment arbitration. The congressional hearings on the proposed Arbitration Fairness Act $^{1}$ (Act) are replete with empirical assertions about the conduct of consumer and employment arbitrations. ${ }^{2}$ Both

* John M. Rounds Professor of Law, University of Kansas School of Law.

** Research Associate, Searle Civil Justice Institute, Northwestern University School of Law. This Article is part of a broader research project and is taken from a Preliminary Report issued by the Consumer Arbitration Task Force, Searle Civil Justice Institute (SCJI), entitled Consumer Arbitration Before the American Arbitration Association (Mar. 2009). Thanks to the SCJI and the University of Kansas for financial and other support for this project. We are exceedingly grateful to the American Arbitration Association, especially Bill Slate, Richard Naimark, Ryan Boyle, and Gerry Strathmann, for providing access to the data and other assistance. We appreciate insightful comments on prior drafts from Lisa Bingham, Geoff Miller, Bo Rutledge, Jason Johnston, Jiro Kondo, and Max Schanzenbach, as well as members of the Searle Board of Overseers and participants in the Searle Center spring research retreat. Henry Butler, Geoff Lysaught, and Judy Pendell also provided helpful comments on drafts, as well as support and oversight throughout this project. Thanks also to Elise Nelson, Matthew Sibery, Jonathan Hillel, and A.J. Noronha for their work in compiling and processing the data, and in helping us ensure the accuracy of the report.

${ }^{1}$ Arbitration Fairness Act, H.R. 1020, 111 th Cong. $\$ 4$ (2009) (making predispute arbitration agreements unenforceable if they require arbitration of any "employment, consumer, or franchise dispute," or "a dispute arising under any statute intended to protect civil rights"); see also Consumer Fairness Act of 2009, H.R. 991, 111 th Cong. $\S 2$ (2009) (making predispute arbitration agreements in consumer contracts unenforceable and "an unfair and deceptive trade act or practice"); Wall Street Reform and Consumer Protection Act of 2009, H.R. 4173, 111 th Cong. \$ 4208(a) (2009) ("The Director, by regulation, may prohibit or impose conditions or limitations on the use of any agreement between a covered person and a consumer for a consumer financial product or service providing for arbitration of any future dispute between the parties if the Director finds that such a prohibition or imposition of conditions or limitations are in the public interest and for the protection of consumers.").

2 See The Arbitration Fairness Act of 2007: Hearing on S. 1782 Before the Constitution Subcomm. of the Senate Comm. on the Judiciary, 110th Cong. (2007) [hereinafter Senate Hearings]; The Arbitration Fairness Act of 2007: Hearing on H.R. 
supporters and opponents of the proposed Act raised empirical issues and analyzed empirical studies in their testimony before Congress, on topics such as the cost of arbitration, ${ }^{3}$ the speed of the process, ${ }^{4}$ and the outcomes for consumers and employees. ${ }^{5}$ Indeed, the disagreement over the state of the empirical record has continued outside of the congressional forum, ${ }^{6}$ with both sides recognizing the importance of relying on sound empirical research rather than anecdotal evidence. ${ }^{7}$ Professor Peter B. Rutledge concludes,

3010 Before the Commercial and Admin. Law Subcomm. of the House Comm. on the Judiciary, 110th Cong. (2007) [hereinafter House Hearings]. For hearings in which the report underlying this article is discussed, see Hearing on Arbitration or Arbitrary: The Misuse of Mandatory Arbitration to Collect Consumer Debts, Subcomm. on Domestic Policy, House Oversight Comm., 111th Cong. (2009); Hearing on the Federal Arbitration Act: Is the Credit Card Industry Using It to Quash Legal Claims?, Subcomm. on Commercial and Admin. Law, House Comm. on the Judiciary, 11 th Cong. (2009).

${ }^{3}$ Senate Hearings, supra note 2, at 4 (Statement of Sen. Sam Brownback); Senate Hearings, supra note 2, at 2 (Statement of Sen. Russell Feingold).

${ }^{4}$ Senate Hearings, supra note 2, at 8 (Statement of Professor Peter B. Rutledge).

5 Senate Hearings, supra note 2, at 17-18 (Statement of F. Paul Bland, Jr.); Senate Hearings, supra note 2, at 15 (Statement of Mark A. de Bernardo); Senate Hearings, supra note 2, at 4 (Statement of Sen. Sam Brownback); Senate Hearings, supra note 2, at 26 (Testimony of Tanya Solov); House Hearings, supra note 2, at 18 (Testimony of Laura MacCleery).

${ }^{6}$ In particular, see the exchange between Public Citizen and Professor Peter B. Rutledge. Compare Public Citizen, The Arbitration Debate TraP: How OpPonents OF CORPORATE ACCOUNTABILITY DistorT THE DEBATE ON ARBITRATION (2008), available at http://www.citizen.org/documents/ArbitrationDebateTrap(Final).pdf [hereinafter PUBlic Citizen, ARBITRATION DEBATE TRAP] and JOHN O'DONNELl, ET AL., Public Citizen, The arbitration Trap: How Credit Card Companies Ensnare CONSUMERS (Sept. 2007), available at http://www.citizen.org/documents/ArbitrationTrap.pdf [hereinafter PUBLIC CITIZEN, ARBITRATION TRAP] with PETER B.

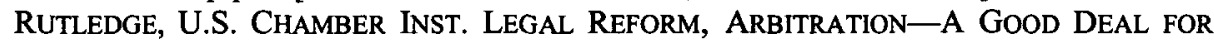
CONSUMERS: A RESPONSE TO PUBLIC CITIZEN 1 (2008), available at $\mathrm{http}: / / \mathrm{www}$.instituteforlegalreform.com/issues/docload.cfm?docId $=1091$ [hereinafter RutLedge, Good DeAL]. See also Peter B. Rutledge, Whither Arbitration?, 6 GEO. J.L. PUB. POL'Y 549 (2008); [hereinafter Rutledge, Whither Arbitration?]; Peter B. Rutledge, Who Can Be Against Fairness? The Case Against the Arbitration Fairness Act, 9 CARDOZO J. CONFLICT RESOL. 267, 271-78 (2008).

${ }^{7}$ See Rutledge, Whither Arbitration?, supra note 6, at 589 (concluding that "[i]ncreased congressional attention" to consumer and employment arbitration "can be valuable, for it promotes discussion and study about this valuable dispute-resolution tool" but also "can be dangerous if the terms of the debate focus too much on anecdote and too little on systematic study"); PUBLIC CITIZEN, ARBITRATION DEBATE TRAP, supra note 6, at 2 ("Rutledge concludes Whither with the warning that congressional scrutiny of 


\section{AN EMPIRICAL STUDY OF AAA CONSUMER ARBITRATIONS}

although perhaps overoptimistically, that "there now appears to be a consensus that the future of arbitration should be decided by data, not anecdote."8

But despite the importance of systematic empirical evidence to Congress and other policymakers when they consider consumer and employment arbitration, the available empirical evidence is limited in important respects. A number of studies have analyzed employment arbitration (particularly as administered by the American Arbitration Association (AAA)) and securities arbitration. ${ }^{9}$ But few studies have examined consumer arbitration in any detail. 10

This article extends our knowledge of consumer arbitration by presenting results from the first detailed empirical study of consumer arbitration as administered by the AAA. Primarily using a sample of 301 AAA consumer arbitrations that resulted in an award between April and December 2007, it considers such issues as the costs incurred by consumers in arbitration, the speed of the arbitral process, and the outcomes of the cases-the very topics of most interest in the policy debate.

Our central findings are the following:

- In cases with claims seeking less than $\$ 10,000$, consumer claimants paid an average of $\$ 96$ ( $\$ 1$ administrative fees $+\$ 95$ arbitrator fees). This amount increases to $\$ 219$ ( $\$ 15$ administrative fees $+\$ 204$ arbitrator fees) for claims between $\$ 10,000$ and $\$ 75,000$. These amounts fall below levels specified in the AAA fee schedule for lowcost arbitrations, and are a result of arbitrators reallocating consumer costs to businesses.

- The average time from filing to final award for the consumer arbitrations studied was 6.9 months. Cases with business claimants were resolved on average in 6.6 months and cases with consumer claimants were resolved on average in 7.0 months.

- Consumers won some relief in $53.3 \%$ of the cases they filed and

arbitration 'can be dangerous if the terms of the debate focus too much on anecdote and too little on systematic study.' We agree.").

${ }^{8}$ Peter B. Rutledge, Common Ground in the Arbitration Debate, 1 Y.B. ARB. \& MED. 1,8 (2009) (emphasis omitted); see also Peter B. Rutledge, The Case Against the Arbitration Fairness Act, DiSP. RESOL. MAG., Fall 2009, at 4, 4 (stating that "it now appears to be common ground that the policy debate over the Arbitration Fairness Act should focus on empirical data").

${ }^{9}$ See infra App. 2.

${ }^{10}$ See infra App. 1. 
recovered an average of $\$ 19,255$; business claimants won some relief in $83.6 \%$ of their cases and recovered an average of $\$ 20,648$.

- Arbitrators awarded attorneys' fees to prevailing consumer claimants in $63: 1 \%$ of cases in which the consumer sought such an award. In those cases in which the award of attorneys' fees specified a dollar amount, the average attorneys' fee award was $\$ 14,574$.

- No statistically significant repeat-player effect was identified using a traditional definition of repeat-player business. Utilizing an alternative definition of repeat player, some evidence of a repeatplayer effect was identified; the data suggest this result may be due to better case screening by repeat players rather than arbitrator bias or other bias in favor of repeat players.

The focus on AAA consumer arbitration is both a benefit of and a limitation on our study. The AAA is a well-known and widely-used provider of arbitration services, for consumers and others. Our findings thus provide insight into consumer arbitrations administered by an important provider of such services. Conversely, our findings necessarily are limited to consumer arbitrations administered by the AAA. Other arbitration providers may administer cases differently. They may attract different types of cases and different types of businesses. Accordingly, one cannot assume that our results are representative of all consumer arbitrations, just as one cannot assume that results from studies of other providers are representative of all consumer arbitrations. To the extent policymakers are deciding whether and how to regulate consumer arbitration, however, additional empirical information on the consumer arbitration process will enable them to make more informed decisions.

Another limitation of the study is that to evaluate the costs, speed, and outcomes of consumer arbitrations, one must have a baseline for comparison; data on arbitration proceedings alone are not enough. Accordingly, while this article's findings provide a look into consumer arbitrations administered by the AAA, further work remains to be done. ${ }^{11}$

Part II of this article provides background on prior empirical studies of consumer arbitration. Part III describes the AAA's consumer arbitration rules. Part IV sets out the research questions we analyze and describes in

11 For an interim report comparing outcomes in debt collection arbitrations to outcomes in debt collection cases in court, see SEARLE CIVIL JUSTICE INST., CREDITOR CLAIMS IN ARBITRATION AND IN COURT (2009), available at http://www.law.northwestern .edu/searlecenter/uploads/Creditor\%20Claims\%20Interim\%20Report\%201 1\%2019\%200 9\%20FINAL2.pdf. 
detail our datasets and research methodologies. Part V presents our research results on the costs, speed, and outcomes of AAA consumer arbitrations. Finally, Part VI concludes by summarizing our central empirical findings and highlighting implications of those findings for the empirical debate.

\section{PRIOR EMPIRICAL RESEARCH ON CONSUMER ARBITRATION-COSTS, SPEED, AND OUTCOMES}

In this Part, we summarize the current empirical literature on consumer arbitration. ${ }^{12}$ Because our focus is on consumer arbitration, with limited exception, we do not discuss empirical studies on securities arbitration or employment arbitration. ${ }^{13}$ Rather, we focus on studies of the arbitration process itself, which address issues such as the cost, speed, and outcome of the arbitration proceeding. ${ }^{14}$ To the extent those studies seek to compare arbitration to litigation, we focus only on the arbitration portion of the study.

12 For a more detailed description of the empirical studies of consumer arbitration discussed in this part, see infra App. 1.

13 For surveys of empirical research on consumer and employment arbitration, see Sarah R. Cole \& Kristen M. Blankley, Empirical Research on Consumer Arbitration: What the Data Reveals, 113 PENN. ST. L. REV. 1051 (2009); Sarah R. Cole \& Theodore H. Frank, The Current State of Consumer Arbitration, Disp. RESOL. MAG., Fall 2008, at 30, 31; Alexánder J.S. Colvin, Empirical Research on Employment Arbitration: Clarity Amidst the Sound and Fury?, 11 EMP. RTS. \& EMP. POL'Y J. 405, 412-37 (2007); Kirk D. Jensen, Summaries of Empirical Studies and Surveys Regarding How Individuals Fare in Arbitration, 60 CONSUMER FIN. L.Q. REP. 631 (2006); Rutledge, Whither Arbitration?, supra note 6, at 556-89 (2008); David Sherwyn, Samuel Estreicher, \& Michael Heise, Assessing the Case for Employment Arbitration: A New Path for Empirical Research, 57 STAN. L. REV. 1557, 1563-78 (2005); see also Christopher R. Drahozal, Arbitration Costs and Forum Accessibility: Empirical Evidence, 41 U. MiCH. J.L. REFORM 813 (2008) (surveying empirical studies of arbitration costs). For a list of empirical studies of employment and securities arbitration, see App. 2. For an empirical study of franchise arbitration and litigation outcomes, based on disclosures in franchise disclosure documents, see Edward Wood Dunham \& David Geronemus, Lessons from the Resolution of Franchise Disputes, JAMS DISP. RESOL. ALERT (JAMS, Irvine, CA, Summer 2003), available at http://www.wiggin.com/db30/cgi-bin/pubs/JAMS\%20article $\% 20 \mathrm{~J} \% 20$ Dunham.pdf.

${ }^{14} \mathrm{We}$ do not consider studies of the provisions of consumer or employment arbitration clauses, e.g., Linda J. Demaine \& Deborah R. Hensler, "Volunteering" to Arbitrate Through Predispute Arbitration Clauses: The Average Consumer's Experience, 67 LAW \& CONTEMP. PROBS. 55, 73-74 (2004), Theodore Eisenberg, Geoffrey P. Miller, \& Emily Sherwin, Arbitration's Summer Soldiers: An Empirical Study of Arbitration Clauses in Consumer and Nonconsumer Contracts, 41 U. MICH. J.L. REFORM 871 (2008); 


\section{A. Costs}

Commentators express conflicting views about the costs of arbitration. A commonly stated view is that arbitration is cheaper than litigation..$^{15}$ Arbitration often is less formal than litigation, with less discovery and less motions practice. ${ }^{16}$ Arbitration awards are subject to limited court review, which may reduce the likelihood of a challenge to an award. ${ }^{17}$ On this view, the costs of arbitrating a dispute may be lower than the costs of litigating a comparable dispute. If so, arbitration may be a more accessible forum for consumers to resolve disputes. ${ }^{18}$

An alternative view is that arbitration is too expensive-that the high costs of arbitration preclude consumers from bringing claims. ${ }^{19}$ A report

studies of outcomes of court cases involving challenges to arbitration agreements, e.g., Christopher R. Drahozal, Arbitration Costs and Contingent Fee Contracts, 59 VAND. L. REV. 729, 752-59 (2006); or studies of outcomes of court cases involving challenges to arbitration awards, e.g., Michael H. LeRoy, Crowning the New King: The Statutory Arbitrator and the Demise of Judicial Review, 2009 J. DISP. RESOL. 1.

15153 CONG. REC. S4614 (daily ed. Apr. 17, 2007) (statement of Sen. Sessions) ("Arbitration is one of the most cost-effective means of resolving disputes."); Lewis L. Maltby, The Myth of Second-Class Justice: Resolving Employment Disputes in Arbitration, in How ADR WORKS 915, 926 (Norman Brand ed., 2002) ("The greatest strength of arbitration is that the average person can afford it.").

16 Stephen J. Ware, Paying the Price of Process: Judicial Regulation of Consumer Arbitration Agreements, 2001 J. DISP. RESOL. 89, 90.

${ }^{17} \mathrm{Id}$.

18 See Allied-Bruce Terminix Cos., Inc. v. Dobson, 513 U.S. 265, 280 (1995) ("[A]rbitration's advantages often would seem helpful to individuals, say, complaining about a product, who need a less expensive alternative to litigation."); Circuit City Stores, Inc. v. Adams, 532 U.S. 105, 123 (2001) ("Arbitration agreements allow parties to avoid the costs of litigation, a benefit that may be of particular importance in employment litigation, which often involves smaller sums of money than disputes concerning commercial contracts.").

19 Press Release, Public Citizen, Arbitration More Expensive than Court-So Costly that Many Victims of Consumer Fraud, Employment Discrimination Give Up (May 1, 2002), available at http://www.citizen.org/pressroom/print_release.cfm? $\mathrm{ID}=1098$ (statement of Joan Claybrook) ("[F]or people who are victims of consumer rip-offs and workplace injustices, arbitration costs much more than litigation-so much more that it becomes impossible to vindicate your rights."); see also Reginald Alleyne, Arbitrator's Fees: The Dagger in the Heart of Mandatory Arbitration for Statutory Discrimination Claims, 6 U. PA. J. LAB. \& EMP. L. 1, 30 (2003); Mark E. Budnitz, The High Cost of Mandatory Consumer Arbitration, 67 LAW \& CONTEMP. PROBS. 133, 161 (2004); Charles L. Knapp, Taking Contracts Private: The Quiet Revolution in Contract Law, 71 FORDHAM L. REV. 761, 781 (2002). 
from Public Citizen issued in 2000 asserted that arbitration is substantially more expensive than litigation, citing the need to pay the arbitrator and any provider of administrative services. ${ }^{20}$ By comparison, parties do not pay judges (except through their tax dollars) and pay a flat, low filing fee to file suit in court. ${ }^{21}$ Under this view, the high upfront costs make arbitration a less accessible forum for consumers. ${ }^{22}$

Most of the empirical evidence on arbitration costs addresses the upfront costs of arbitration and does not consider costs such as attorneys' fees, internal expenses, and opportunity costs associated with resolving the dispute itself. ${ }^{23}$ The Public Citizen report on the Costs of Arbitration presented a series of case studies with an analysis of the costs of arbitrating and litigating four hypothetical cases, in reaching its conclusion that arbitration costs "have a deterrent effect, often preventing a claimant from even filing a case."24

By comparison, Mark. Fellows reported that consumer claimants in National Arbitration Forum (NAF) arbitrations in 2003-2004 paid arbitration fees averaging $\$ 46.63$ while business claimants paid arbitration fees averaging $\$ 149.50 . .^{25}$ Similarly, Navigant Consulting, relying on NAF data

${ }^{20}$ E.g., JaCKSON Williams, Public Citizen, The Costs of ARbitration 1 (2002) available at http://www.citizen.org/documents/ACF110A.pdf ("The cost to a plaintiff of initiating an arbitration is almost always higher than the cost of instituting a lawsuit. Our comparison of court fees to the fees charged by the three primary arbitration provider organizations demonstrates that forum costs - the costs charged by the tribunal that will decide the dispute - can be up to five thousand percent higher in arbitration than in court litigation.") (emphasis in original).

21 Drahozal, supra note 14, at 736-37.

22 For a possible reconciliation of these competing views about arbitration costs, see id. at $734-35$.

${ }^{23}$ For empirical evidence on business cost savings from arbitration (including attorneys' fees in handling the cases), see the studies discussed in Drahozal, supra note 13, at 829-30; see also Herbert M. Kritzer \& Jill K. Anderson, The Arbitration Alternative: A Comparative Analysis of Case Processing Time, Disposition Mode, and Cost in the American Arbitration Association and the Courts, 8 JUST. SYS. J. 6, 17 (1983) (studying fees received by attorneys in sample of AAA commercial arbitrations and uninsured motorist arbitrations, state court cases, and federal court cases: "The AAA is least expensive for small cases, and most expensive for the remaining three categories. ... At the same time, in a sense, one gets 'more' for the money in terms of the amount of institutional processing, with the AAA, because a much larger proportion of cases go through the 'complete process,' including a hearing and an award.").

24 WILliaMs, supra note 20 , at 1, 6-51.

${ }^{25}$ Mark Fellows, The Same Result as in Court, More Efficiently: Comparing Arbitration and Court Litigation Outcomes, METRO. CORP. COUNSEL, July 2006, at 32. 
from January 2003 through March 2007, concluded that consumers paid no fee in $99.3 \%$ of the cases (presumably those brought by businesses) and a median fee of $\$ 75$ in the remaining 246 cases. ${ }^{26}$ Ernst \& Young reported in 2004 that the average fee paid in consumer "banking" arbitrations administered by the AAA was $\$ 1935$, but the data were incomplete as to how the fees were allocated between consumers and businesses. ${ }^{27} \mathrm{~A}$ study by the California Dispute Resolution Institute (CDRI), looking at data disclosed by six arbitration providers from January 2003 to February 2004, found a mean arbitration fee of $\$ 2256$ and a median arbitration fee of $\$ 870 .{ }^{28}$ But the data used by the CDRI were incomplete, did not separate out the fees paid by consumers from the fees paid by businesses, ${ }^{29}$ and included both consumer and employment cases. ${ }^{30}$

\section{B. Speed}

Arbitration also is commonly perceived to be a faster dispute resolution process than litigation. ${ }^{31}$ The reasons are at least twofold. First, again, arbitration is less formal than litigation, with less discovery and fewer

${ }^{26}$ Memorandum from Jeff Nielsen et al. re: National Arbitration Forum: California Consumer Arbitration Data 3 (July 18, 2003), available at http://www. instituteforlegalreform.com/get_ilr_doc.php?docId=1212.

27 ERNST \& YOUNG, OUTCOMES OF ARBITRATION: AN EMPIRICAL STUdY OF CONSUMER LENDING CASES 16-17, App. A (2004), available at http://www.adrforum .com/rcontrol/documents/ResearchStudiesAndStatistics/2005ErnstandYoung.pdf.

28 CAL. DISP. RESOL. INST., CONSUMER AND EMPLOYMENT ARBITRATION IN California: A ReVIew of Website Data Posted Pursuant to Section 1281.96 of THE CODE OF CIVIL PROCEDURE 21 (Aug. 2004), available at http://www.mediate. com/cdri/cdri print_aug_6.pdf. The six providers were the AAA, ADR Services, Arbitration Works, ARC Consumer Arbitrations, JAMS, and Judicate West. Id. at 14.

${ }^{29} \mathrm{Id}$. at 18 ("In general, inconsistencies, ambiguities and the lack of reported data ... limit this study's utility for the purposes of informing policy ...."); see also Lisa Blomgren Bingham et al., Conference Presentation at the ABA Section of Dispute Resolution Conference, Los Angeles, CA: Arbitration Data Disclosure in California: What We Have and What We Need 20 (Apr. 15, 2005) (concluding that "the private arbitration service providers in question are not providing the information that is critical to an analysis of how the consumer party fare[s] in commercial arbitration").

30 CALIFORNIA DISPUTE RESOLUTION INST., supra note 28 , at 17, 22 fig. 1 .

31 Allied-Bruce Terminix Cos. v. Dobson, 513 U.S. 265, 280 (1995) (quoting H.R. Rep. No. 97-542, at 13 (1982) ("“The advantages of arbitration are many: it is usually cheaper and faster than litigation; it can have simpler procedural and evidentiary rules...."')). 


\section{AN EMPIRICAL STUDY OF AAA CONSUMER ARBITRATIONS}

motions, and appellate review of awards is limited..$^{32}$ Second, arbitration may have less of a queue than litigation-parties can choose an arbitrator who does not have a backlog of cases, so that they can avoid waiting behind other parties to have their dispute resolved. ${ }^{33}$

The empirical evidence shows consumer arbitration to be an expeditious process. ${ }^{34}$ In 2007, the AAA reported that, on average, its consumer cases took four months to resolve on the basis of documents and six months to resolve on the basis of in-person hearings. ${ }^{35}$ For 2006, the numbers were similar: an average of 3.8 months for document-only cases and 7.4 months for cases decided after in-person hearings. ${ }^{36}$ Mark Fellows found that the NAF's average disposition time from 2003 to 2004 for consumer claimants was 4.35 months and for business claimants was 5.60 months. ${ }^{37}$ The CDRI study of six arbitration providers from January 2003 to February 2004 found a mean disposition time of 116 days and a median disposition time of 104 days, ${ }^{38}$ although as noted above, the data are incomplete and problematic. ${ }^{39}$

32 See id.

33 Richard A. Posner, The Cost of Rights: Implications for Central and Eastern Europe-And for the United States, 32 TULSA L.J. 1, 15 (1996) ("The longer the queue, the greater the incentive of the parties to a dispute to substitute arbitration or other nonjudicial methods of dispute resolution for the courts ...."); Hon. Diane P. Wood, Snapshots from the Seventh Circuit: Continuity and Change, 1966-2007, 2008 WIS. L. REV. 1, 6 (stating that "to the extent that litigants wish to avoid these queues, they are opting out of the judicial system altogether and turning to arbitration and mediation.").

${ }^{34}$ See Kritzer \& Anderson, supra note 23, at 17 (finding that "the American Arbitration Association offers the possibility of relatively fast adjudication (compared to relatively slow nonadjudication in the courts).").

35 AM. ARB. ASS'N, ANALYSIS OF THE AMERICAN ARBITRATION ASSOCIATION'S CONSUMER ARBITRATION CASEload: BaSed on CONSUMER CASES AWARded BETwEen JANUARY AND AUGUST 2007 (2007), available at http://www.adr.org/si.asp?id=5027 [hereinafter AAA, 2007 Caseload Analysis].

36 Statement of the American Arbitration Association, Annex D, in The Arbitration Fairness Act of 2007: Hearing on S. 1782 Before the Constitution Subcomm. of the Senate Comm. on the Judiciary, 110th Cong. 135 (2007) [hereinafter AAA, 2006 Caseload Analysis].

${ }^{37}$ Fellows, supra note 25 , at 32.

38 CALIFORNIA DISPUTE RESOlUtion INST., supra note 28, at 19. Actually, in comparison to other variables in the study, the CDRI data on time of disposition is more complete, covering 1559 of 2175 cases. Id.

39 See supra text accompanying notes 29-30. 


\section{Outcomes}

An important subject of empirical research is how consumers fare in arbitration. Several ways to measure outcomes have been used, including the win rate, the amount of damages recovered, and the amount of damages recovered as a percentage of the amount claimed. Two points of particular interest are how arbitration outcomes compare to outcomes in court, which is beyond the scope of this Article, and whether outcomes are biased in favor of repeat players.

Win rates. Studies have most commonly looked at the win rate in arbitration, defined as the percentage of cases won by the consumer or the business. But the absolute win rate itself is not a particularly meaningful number. Instead, the absolute win rate must be compared to a baseline. Some commentators have focused on fifty percent as that baseline. ${ }^{40}$ Others have suggested that an extremely high business win rate shows a process that is unfair to consumers. ${ }^{41}$ Neither view is necessarily correct.

At least two possible approaches are available for identifying a proper baseline for comparison. One possible approach is to use a theoretical model of case settlement, which generates predictions about expected outcomes. ${ }^{42}$ Some models lead to predictions of a fifty percent win rate, providing some support for using that figure as a baseline. ${ }^{43}$ Other models, based on different

40 Rutledge, Whither Arbitration?, supra note 6, at 559 n.36 (stating that "the only reported data showing a win-rate of less than $50 \%$ is William Howard's study of securities arbitration"); PUBLIC CITLZEN, THE ARBITRATION DEBATE TRAP, supra note 6, at 16 ("In fact, at least five other studies have found win rates of less than 50 percent for individual claimants ....").

41 Public Citizen, Arbitration Trap, supra note 6, at 13 (referring to the "truly staggering success rate" of businesses in NAF arbitrations); Letter from Professors of Consumer Law and Banking Law to Senators Dodd and Shelby and Congressmen Frank and Bachus, Statement in Support of Legislation Creating a Consumer Financial Protection Agency 6 (Sept. 29, 2009), available at http://law.hofstra.edu/pdf Media/consumer-law\%209-28-09.pdf ("Studies have found the arbitrators find for companies against consumers 94 to $96 \%$ of the time, suggesting that arbitration providers are responding to the incentive to find for those who select them: the companies that insert their names in their form contracts.").

42 Joel Waldfogel, Selection of Cases for Trial, in 3 THE New Palgrave Dictionary OF ECONOMICS AND THE LAW 419, 419 (Peter Newman ed., 1998) (suggesting that "any model of the settlement decision is also at least implicitly a model of the selection of cases for trial").

${ }^{43}$ E.g., George L. Priest \& Benjamin Klein, The Selection of Disputes for Litigation, 13 J. LEGAL STUD. 1, 17-20 (1984). 
assumptions, lead to predictions of extremely high (or low, depending on the perspective) win rates. ${ }^{44}$

A second approach is to compare outcomes in arbitration to outcomes in litigation. A business win rate of over ninety percent in arbitration does not show that arbitration is unfair if the win rate for comparable cases in court is similar. ${ }^{45}$ But doing a proper comparison can be difficult. ${ }^{46}$ Certainly, care must be taken to ensure that the types of cases are reasonably comparable, as well as to control for other differences between arbitration and litigation, such as the greater use of summary judgment and other dispositive motions in litigation. ${ }^{47}$

Studies of win rates in consumer arbitrations show various degrees of consumer and business success. Two studies conducted by the AAA of its consumer arbitration caseload in 2006 and 2007 found that consumer plaintiffs won $48 \%$ of the awarded cases they brought. ${ }^{48}$ The 2007 study found that business claimants won $74 \%$ of the awarded cases they brought. ${ }^{49}$

Most of the data on outcomes in consumer arbitration have come from studies conducted on the NAF's caseload. ${ }^{50}$ Unusual among the leading

44 Id. at 24-29; see also, e.g., Luke Froeb, The Adverse Selection of Cases for Trial, 13 INT'L REV. L. \& ECON. 317 (1993); Keith N. Hylton, Asymmetric Information and the Selection of Disputes for Litigation, 22 J. LEGAL STUD. 187 (1993).

45 See RUTLEDGE, GoOD DEAL, supra note 6, at 11 ("Studies of debt collection actions in major cities reveal[] that the lender typically wins between $96 \%$ and $99 \%$ of the time, right in line with the lender win-rate data cited in the Public Citizen Report."); SEARLE CIVIL JUSTICE INST., supra note 11, at 4-5.

46 E.g., Stephen J. Ware, The Effects of Gilmer: Empirical and Other Approaches to the Study of Employment Arbitration, 16 OHIO ST. J. ON DISP. RESOL. 735, 755-56 (2001); W. Mark C. Weidemaier, From Court-Surrogate to Regulatory Tool: ReFraming the Empirical Study of Employment Arbitration, 41 U. MICH. J.L. REFORM 843, 852-56 (2008).

${ }^{47}$ Lewis Maltby, Employment Arbitration: Is It Really Second Class Justice?, DiSP. RESOL. MAG., Fall 1999, at 23, 23-24; Weidemaier, supra note 46, at 853.

48 AAA, 2007 Caseload Analysis, supra note 35, at 1; AAA, 2006 Caseload Analysis, supra note 36 , at 135 .

49 AAA, 2007 Caseload Analysis, supra note 35, at 1.

50 On July 14, 2009, the Minnesota Attorney General brought suit against the NAF, alleging fraud and deceptive practices. Compl., Minn. v. Nat'l Arbitration Forum, Inc., No. 27-CV-09-18550 (Minn. Dist. Ct. July 14, 2009), available at http://www.ag.state.mn.us/PDF/PressReleases/SignedFiledComplaintArbitrationCompan y.pdf. NAF entered into a consent judgment on July 17, 2009, agreeing permanently to stop administering new consumer arbitrations. Minn. v. Nat'l Arbitration Forum, Inc., No. 27-CV-09-18550, Consent Judgment, at I 3, (Minn. Dist. Ct. July 17, 2009), 
arbitration providers, ${ }^{51}$ NAF's consumer caseload consisted almost exclusively of debt collection actions, the majority brought by a single credit card company. ${ }^{52}$ Although there is some disagreement on how to treat cases dismissed before an award, 53 studies consistently showed a high win rate for business claimants in NAF arbitrations, ranging from $67.9 \%$ to over $99 \% .54$ By comparison, the win rate for consumer claimants before the NAF was much higher than the win rate for consumer respondents, although again studies disagree over the actual win rate (with reports ranging from $37.2 \%$ to $65.5 \%) .{ }^{55}$ Moreover, consumers brought only a handful of NAF arbitrations each year. 56

available at $\mathrm{http}: / /$ pubcit.typepad.com/files/nafconsentdecree.pdf.

51 By comparison, see the AAA consumer caseload described infra Part V.A.1; see also W. Mark C. Weidemaier, The Arbitration Clause in Context: How Contract Terms Do (and Do Not) Define the Process, 40 CREIGHTON L. REV. 655, 674 (2007) (reporting that $98.7 \%$ of JAMS consumer arbitrations from 2003-2006 were brought by the consumer as claimant, as compared to $0.4 \%$ of NAF consumer arbitrations during the same period).

52 PUBliC CITIZEN, ARBITRATION TRAP, supra note 6, at 15 ("all but 15 of the 33,948 cases are labeled 'collection' cases"); id. at 17 ("MBNA's NAF arbitration cases, including those filed by debt buyers who purchased MBNA accounts, totaled 18,101 and represented 53.3 percent of the NAF California cases.").

53 Compare Nielsen et al., supra note 26, at 1 (including dismissals with cases in which consumers prevailed outright) with PUBLIC CITIZEN, ARBITRATION DEBATE TRAP, supra note 6, at 10-11 (arguing that dismissals before an arbitrator is appointed "can hardly be used as evidence of the fairness of NAF arbitration," and that dismissals after an arbitrator is appointed might have resulted from "any number of manipulative reasons" and should not be counted as consumer wins).

54 Fellows, supra note 25 , at 32 (business claimants "prevail in $77.7 \%$ of the cases that reach a decision"); Nielsen et al., supra note 26, at 1 (businesses prevailed in $67.9 \%$ of NAF arbitrations either heard by an arbitrator or dismissed); PUBLIC Citizen, ARBITRATION TRAP, supra note 6, at 15 (stating that in 19,294 cases in which an arbitrator was appointed, the business won in 18,091 (or 93.8\%)); Answers and Objections of First USA Bank, N.A. to Plaintiff's Second Set of Interrogatories, Ex. 1, Bownes v. First U.S.A. Bank, N.A., Civ. Action No. 99-2479-PR (Ala. Cir. Ct. 2000), available at http://www.publicjustice.net/Repository/Files/McQuillanExhibit_16-19.pdf (last visited Feb. 2, 2010) [hereinafter First USA Interrogatory Answers] (bank prevailed in 19,618 NAF arbitrations, while credit cardholder prevailed in 87).

55 ERNST \& YOUNG, supra note 27, at 9 (indicating a win rate for consumer claimants of $54.6 \%$ ); Fellows, supra note 25 , at 32 (indicating a win rate for consumer claimants of 65.5\%); PUBlic CITIZEN, ARBITRATION DEBATE TrAP, supra note 6, at 10 (indicating a win rate for consumer claimants of $37.2 \%$ ).

56 PUBlic CitZEen, ARBITRATION TRAP, supra note 6, at 15 (reporting that $0.35 \%$ of all NAF arbitrations involved consumer claimants). 
Monetary Recoveries. A frequent criticism of studies of win rates in arbitration and litigation is that the usual way of measuring party wins is too simplistic. In many studies, a claimant "win" is defined to include any case in which the claimant was awarded some amount of money, while a respondent "win" is defined to include only cases in which the respondent is held liable for zero damages. ${ }^{57}$ Such an approach may understate the number of respondent wins and overstate the number of claimant wins because a claimant with a strong claim for a large amount is treated as "winning" even if awarded an amount that is far less than the claim is worth. ${ }^{58}$

But it is difficult to value claims for purposes of empirical research. Ordinarily, researchers do not have complete information about the claims, and, even if they do, it would be extremely difficult to evaluate objectively how much a claim is worth at the time it is brought. As a result, some studies have used the amount sought by the claimant as a proxy for the value of the claim, calculating the amount awarded as a percentage of the amount claimed. ${ }^{59}$

Even this approach, which uses the amount claimed as a proxy for the value of the claim, is difficult to implement. First, plaintiffs in court often do not demand a specific amount in any court filing; they may simply plead that the minimum jurisdictional amount is satisfied. Arbitration would seem to be less subject to this problem because arbitration fees are typically based on the amount of compensatory damages sought. ${ }^{60}$ But even in arbitration, as discussed below, determining a single dollar amount claimed can be difficult. 61

Second, in both settings, merely because a party claims a particular amount does not mean that the claim is worth that amount. Plaintiffs may seek amounts of damages that they have only a small likelihood of

${ }^{57}$ E.g., AAA, 2006 Caseload Analysis, supra note 36, at 135.

58 Rutledge, Whither Arbitration?, supra note 6, at 557. That said, as discussed infra text accompanying note 62 , the fact that the claimant recovered a small percentage of the amount claimed does not necessarily mean that the outcome was somehow incorrect. See PUblic Citizen, ARBitration Debate TraP, supra note 6, at 12 (asserting that definition of claimant "win" is "unreliable" when it classifies a "claimant who sought $\$ 50,000$ and received only $\$ 5$ " as a win for claimant). Whether that is so depends not merely on the amount of the claim, but also on the strength of the claim.

${ }^{59}$ E.g., Lewis L. Maltby, Private Justice: Employment Arbitration and Civil Rights, 30 COLUM. HUM. RTS. L. REV. 29, 48 (1998).

${ }^{60}$ See infra Part III.

61 See infra Part V.A.2. 
recovering. ${ }^{62}$ The value of such a claim can be much less than the amount sought. Indeed, the fact that a plaintiff does not recover such an amount does not necessarily mean the process failed; rather, it can mean that the process worked properly.

Third, the incentives of the parties to claim damages differ depending on whether a party is litigating or arbitrating a dispute. In court, subject to credibility constraints, the plaintiff's incentive is to claim more, rather than less, in damages. Court filing fees are a flat amount that does not increase with the amount claimed. ${ }^{63}$ Meanwhile, claiming higher damages amounts may increase the amount the plaintiff recovers. Experimental studies have found that the amount sought by a plaintiff-even if ridiculously large-can act as an anchor and increase the amount of damages awarded by a mock jury. ${ }^{64}$ By comparison, because of the way arbitration fees are structured, the claimant in arbitration often has to pay more to claim more. ${ }^{65}$ As a result, amounts claimed in arbitration may be more realistic than amounts claimed in court. ${ }^{66}$ If so, this complicates comparisons between arbitration and litigation, because a higher percentage recovery in arbitration may be due to more realistic amounts claimed rather than any difference in the amount awarded. ${ }^{67}$

A few studies have examined amounts awarded in consumer arbitrations. ${ }^{68}$ The CDRI found that the mean amount awarded in a sample of California cases administered by six different providers (including the AAA) was $\$ 33,112$, while the median award was $\$ 7615 . .^{69}$ But data were available

62 This is the case even if the plaintiff has a meritorious claim because some elements of the plaintiff's damages recovery may be highly uncertain.

63 Drahozal, supra note 14 , at 736-37.

${ }^{64}$ E.g., Gretchen B. Chapman \& Brian H. Bornstein, The More You Ask For, the More You Get: Anchoring in Personal Injury Verdicts, 10 APPLIED COGNITIVE PSYCHOL. 519, 526-27 (1996). See generally Christopher R. Drahozal, A Behavioral Analysis of Private Judging, 67 LAW \& CONTEMP. PROBS. 105, 110-11 \& n.28 (2004) (describing studies).

65 Drahozal, supra note 64, at 129.

66 Id. In addition, parties may be subject to countervailing (or reinforcing) incentives to the extent the success rate in arbitration varies depending on the amount sought.

${ }^{67}$ See Christopher R. DRAHOzal, COMMERCIAL ARBITRATION: CASES AND Problems 7 (2d ed. 2006).

68 By comparison, many more studies of employment arbitration report the amounts of awards, including some that report the amount awarded as a percentage of the amount claimed. See infra App. 2.

${ }^{69}$ CALIFORNIA DiSPUTE RESOlUtion INST., supra note 28, at 20. 


\section{AN EMPIRICAL STUDY OF AAA CONSUMER ARBITRATIONS}

on the amount awarded in only 540 of the 2175 cases in the sample, "limit[ing] this study's utility for the purposes of informing policy."70

Navigant Consulting found that the arbitrator reduced the amount of the business's claim in $16.4 \%$ of the NAF arbitrations studied, with a median reduction of $\$ 636$ and a median percentage reduction of $8.6 \% .^{71}$ In the remaining $83.6 \%$ of the cases, presumably the business was awarded the full amount claimed. According to data presented by Public Citizen, NAF arbitrators who decided more than 100 cases in California awarded businesses $92.4 \%$ of the total amount they sought. ${ }^{72}$ Note that Public Citizen apparently included amounts sought by businesses in cases in which the consumer prevailed outright (that is, in which the business recovered nothing) in the total amount sought. ${ }^{73}$

Repeat-Player Effect. Unlike judges, arbitrators get paid only when selected to arbitrate a dispute. This economic reality of arbitration has given rise to fears of "repeat-arbitrator bias"-the view that arbitrators will decide cases in favor of the repeat player, which is the party more likely to be in a position to appoint the arbitrator to serve again. ${ }^{74}$ In consumer arbitration, consumers are unlikely to be repeat players (although their attorneys may be). ${ }^{75}$ Thus, the fear is that arbitrators will tend to favor businesses in the

${ }^{70} \mathrm{Id}$. at 18.

71 Nielsen et al., supra note 26, at 3.

72 Public Citizen, ARBITRATION TRAP, supra note 6, at 16 (those arbitrators awarded businesses $\$ 185,479,341$ of $\$ 200,736,495$ sought).

${ }^{73}$ Navigant used the same dataset as Public Citizen, see Nielsen et al., supra note 26 , at 1 , and Navigant's reported reductions otherwise would be much too small relative to the amounts of the awards.

${ }^{74}$ E.g., Richard M. Alderman, Pre-Dispute Mandatory Arbitration in Consumer Contracts: A Call for Reform, 38 Hous. L. REV. 1237, 1256 (2001); David S. Schwartz, Enforcing Small Print to Protect Big Business: Employee and Consumer Rights Claims in an Age of Compelled Arbitration, 1997 WIS. L. REV. 33, 60-61; see also PUBLIC CiTIZEN, ARBITRATION DEBATE TRAP, supra note 6, at 24-26. In addition to concerns that arbitrators might be biased in favor of repeat businesses, the same argument is directed at arbitration providers. E.g., Arbitration Fairness Act, H.R. 1020, 111 th Cong. § 2(4) (2009) (finding that "[p]rivate arbitration companies are sometimes under great pressure to devise systems that favor the corporate repeat players who decide whether those companies will receive their lucrative business").

75 Budnitz, supra note 19, at 138 n.22; Carrie Menkel-Meadow, Ethics Issues in Arbitration and Related Dispute Resolution Processes: What's Happening and What's Not, 56 U. Miami L. REV. 949, 956 (2002). Compare Samuel Estreicher, Saturns for Rickshaws: The Stakes in the Debate over Predispute Employment Arbitration Agreements, 16 OHIO ST. J. ON DISP. RESOL. 559, 566 (2001) ("[T] he real repeat players 
hopes of being selected for future cases more frequently. More broadly, commentators have expressed concerns about what might be called "repeatplayer bias" (rather than repeat-arbitrator bias)-bias that results from businesses structuring the dispute resolution process in their favor. ${ }^{76}$

Several factors may reduce the likelihood or consequences of repeatarbitrator or repeat-player bias. First, arbitration providers, as well as individual arbitrators, may seek to maintain a reputation for fair and unbiased decision making. ${ }^{77}$ Such reputational constraints may reduce the risk that repeat-arbitrator or repeat-player bias will occur. Second, even if arbitrators and arbitration providers have an incentive to make decisions that businesses want, it is not necessarily the case that those decisions will be unfavorable to consumers. As Gordon Tullock explains, while "a bias toward the retailer might be the arbitrator's profit-maximizing course of action," it might not be. Instead, "the retailer might be interested in his general reputation and want an arbitrator who was either impartial or, for that matter, actually procustomer." 78 For example, even though the workers at return desks are employed by the retailer to resolve disputes with customers who are seeking to return goods for a refund, "their usual reaction is not one of making a fair judicial decision between themselves and [the customer] but of giving [the customer] every benefit of the doubt." 79

In the consumer context, Public Citizen has argued that debt collection arbitration before the NAF is affected by repeat-arbitrator bias. It cites both anecdotal reports ${ }^{80}$ and evidence that the arbitrators most commonly

in arbitration are not the parties themselves but the lawyers involved.") with Lisa B. Bingham, Employment Arbitration: The Repeat Player Effect, 1 EMP. RTs. \& EMP. POL'Y J. 189, 198-99 (1997) (stating that "there is reason to believe that most individual members of the plaintiffs' bar may never successfully emerge as repeat players in employment arbitration").

76 Lisa B. Bingham, Control Over Dispute-System Design and Mandatory Commercial Arbitration, 67 LAW \& CONTEMP. PROBS. 221, 231-39 (2004); Lisa B. Bingham, Self-Determination in Dispute System Design and Employment Arbitration, 56 U. MIAMI L. REV. 873, 889-92 (2002) [hereinafter Bingham, Self-Determination].

77 Christopher R. Drahozal, “Unfair” Arbitration Clauses, 2001 U. ILL. L. REV. 695, 769-70; see also Weidemaier, supra note 51, at 661-62 (arguing that arbitration providers may "confer legitimacy" by "adopt[ing] or enforc[ing] due process or 'fairness' rules").

78 Gordon Tullock, Trials on Trial: The Pure Theory of Legal Procedure $127-28$ (1980).

79 Id. at 128.

80 Public Citizen, Arbitration Trap, supra note 6, at 30-32; Public Citizen, ARBITRATION DEBATE TRAP, supra note 6, at 24-25. 
appointed by the NAF are more likely to rule in favor of business claimants than other arbitrators. ${ }^{81}$

In the employment context, although several studies have identified a repeat-player effect, they have not found evidence of repeat-player bias. For example, employees win less often against repeat businesses-businesses that arbitrate on a repeat basis - than against non-repeat businesses. This repeat-player effect might be due to repeat-arbitrator or repeat-player bias, but it might also be due to better screening of cases by repeat businesses, who are more accustomed to dealing with disputes than non-repeat businesses. If repeat businesses are more likely to settle weak claims than non-repeat businesses, they will have a higher win rate in cases that go to an award than non-repeat businesses.

For example, in a study of 270 AAA employment arbitration awards from 1993 and 1994, Lisa Bingham found that employees won some relief in $63 \%$ of all awards in cases they brought, but won some relief in only $16 \%$ of awards against repeat employers. ${ }^{82}$ Similarly, employees recovered $48 \%$ of their amount claimed against non-repeat employers, but only $11 \%$ of their amount claimed against repeat employers. ${ }^{83}$ Bingham's results from a subsequent study of 203 AAA employment awards from 1993 to 1995 were similar. ${ }^{84}$ But Bingham's evidence indicated that the repeat-player effect was a result, not of repeat-arbitrator or repeat-player bias, but of differences in the cases arbitrated. ${ }^{85}$ The same is true of yet another study by Bingham, this one co-authored with Shimon Sarraf, which examined AAA employment awards

81 Public Citizen, Arbitration Trap, supra note 6, at 16.

82 Bingham, supra note 75, at 189-90 (defining repeat employer as one involved in more than one case in her sample).

$83 \mathrm{Id}$. at 213. For discussions of methodological issues in Bingham's studies, see Sherwyn et al., supra note 13, at 1570 .

84 Lisa B. Bingham, Unequal Bargaining Power: An Alternative Account for the Repeat Player Effect in Employment Arbitration, IRRA 50TH ANN. PROC. 33, 38-39 (1998) [hereinafter Bingham, Unequal Bargaining Power]; Lisa B. Bingham, On Repeat Players, Adhesive Contracts, and the Use of Statistics in Judicial Review of Employment Arbitration Awards, 29 MCGEORGE L. REV. 223, 223 (1998); see also Lisa B. Bingham, An Overview of Employment Arbitration in the United States: Law, Public Policy and Data, N.Z. J. INDUSTRIAL REL., June 1998, at 5, 15 (reporting an employee win rate of $25.0 \%$ in cases with a repeat arbitrator as compared to an employee win rate of $55.5 \%$ in cases with a non-repeat arbitrator).

85 Bingham, Unequal Bargaining Power, supra note 84, at 39-40. Bingham found that " $[r]$ epeat player employers get to arbitration based on an implied contract stemming from a personnel manual or employee handbook," cases in which the employee "may have a substantively weaker legal claim." Id. 
from 1996 and $1997 .{ }^{86}$ Bingham and Sarraf found an employee win rate of $29 \%$ against repeat employers as compared to an employee win rate of $62 \%$ against non-repeat employers. But they found no evidence this was due to repeat-arbitrator or repeat-player bias. Rather, the repeat-player effect was likely the result of case screening by employers with in-house dispute resolution programs..$^{87}$ Nonetheless, Bingham's studies continue, incorrectly, to be cited as evidence of repeat-arbitrator bias. ${ }^{88}$

Elizabeth Hill found what she described as an "appellate effect" in her study of 200 AAA employment awards from 1999 to $2000 .{ }^{89}$ Of the 34 cases with repeat employers in her sample, 25 (or 74\%) involved employers with an in-house dispute resolution program. The employee win rate in those cases was substantially below the employee win rate in the other cases in the sample, and substantially below the win rate in cases involving the other repeat employers. ${ }^{90}$ The differences were not statistically significant, but her

${ }^{86}$ Lisa B. Bingham \& Shimon Sarraf, Employment Arbitration Before and After the Due Process Protocol for Mediation and Arbitration of Statutory Disputes Arising Out of Employment: Preliminary Evidence that Self-Regulation Makes a Difference, in Alternate Dispute Resolution In the EMPloyment ARENA: Proceedings of THE NEW YORK UNIVERSITY 53RD ANNUAL CONFERENCE ON LABOR 303, 320-28 (Samuel Estreicher \& David Sherwyn eds., 2004); see also Bingham, Self-Determination, supra note 76 , at $899-901$.

${ }^{87}$ Bingham \& Sarraf, supra note 86, at 323 tbl.2; see Sherwyn et al., supra note 13, at 1571 (describing Bingham \& Sarraf's results and concluding that "[ $\mathrm{t}] \mathrm{h}$ hese results suggest that the availability of an internal review process and the employer's experience with employment cases likely explains the repeat player effect. Bingham found no support for arbitrator bias.").

88 David S. Udell \& Rebekah Diller, Access to the Courts: An Essay for the Georgetown University Law Center Conference on the Independence of the Courts, 95 GEO. L.J. 1127, 1152 (2007) ("[I]n many contexts, arbitrators have been shown to develop a bias in favor of so-called repeat players.") (citing Lisa B. Bingham, Employment Arbitration: The Repeat Player Effect, 1 EMP. RTS. \& EMP. POL'Y J. 189, 205-10 (1997)).

89 Elizabeth Hill, Due Process at Low Cost: An Empirical Study of Employment Arbitration Under the Auspices of the American Arbitration Association, 18 OHIO ST. J. ON DisP. ReSOL. 777, 807-08 (2003) [hereinafter Hill, Due Process]; Elizabeth Hill, $A A A$ Employment Arbitration: A Fair Forum at Low Cost, DiSP. RESOL. J., May/July 2003, at 9 [hereinafter Hill, Fair Forum].

${ }^{90}$ Hill, Due Process, supra note 89, at 817; Hill, Fair Forum, supra note 89, at 15. Rather than reporting an employee win rate, Hill reports an employer win-loss ratiodividing the number of employer wins by the number of employer losses. For repeat employers with an in-house dispute resolution program, the employer win-loss ratio was 3.2; for repeat employers without an in-house dispute resolution program, the employer 


\section{AN EMPIRICAL STUDY OF AAA CONSUMER ARBITRATIONS}

sample size was too small for reliable statistical testing. ${ }^{91}$ Based on her data, Hill attributes the repeat-player effect to "the selection processes of large employers' in-house dispute resolution programs," rather than "merely the by-product of large employers' repeat appearances at arbitration."92 Hill found no evidence of repeat-arbitrator bias, as there were only two cases in her sample involving the same arbitrator and employer. ${ }^{93}$

Most recently, Alexander Colvin examined a sample of 836 awards in employment arbitrations administered by the AAA from January 1, 2003 to September $30,2006 .{ }^{94}$ Because the data were from the AAA's disclosures as required by California law, the cases involved arbitrations "based on employer promulgated agreements," rather than "individually negotiated agreements." 95 Colvin found an employee win rate of $13.9 \%$ in cases against repeat employers as compared to an employee win rate of $32.0 \%$ in cases against non-repeat employers, a statistically significant difference. ${ }^{96}$ The employee win rate in cases involving a repeat employer appearing before the same arbitrator (a "repeat employer-arbitrator pair") was $11.3 \%$ as compared to an employee win rate of $21.2 \%$ in cases not involving a repeat employerarbitrator pair. ${ }^{97}$ Colvin then limited the sample to cases with repeat

win-loss ratio was 1.25 . For all employers, the employer win-loss ratio was 1.3. Hill, Due Process, supra note 89, at 817; Hill, Fair Forum, supra note 89, at 15.

91 Colvin, supra note 13, at 428-29 ("Hill did not provide any tests of the statistical significance of the difference between the in-house program and no in-house program groups, however a simple chi-square test on the results presented indicates that the difference is not statistically significant."); see also Sherwyn et al., supra note 13, at 1572 ("Of course, samples of thirty-four, twenty-five, and nine are too small to yield reliable conclusions ....").

92 Hill, Fair Forum, supra note 89, at 15; see also Hill, Due Process, supra note 89, at 817 .

93 Hill, Due Process, supra note 89, at 814-15; Hill, Fair Forum, supra note 89, at 15. Hill also argues that "the total number of arbitrators on the AAA panel in contrast to the annual number of arbitrations shows that it is unlikely that any individual arbitrator would have appeared with sufficient frequency to seek to reward 'repeat player' employers," pointing out that "[t]here were 560 arbitrators on the AAA's employment arbitration panel in 1999-2000" and "only 432 awards rendered in 1999 and 410 rendered in 2000." Hill, Due Process, supra note 89, at 815.

${ }^{94}$ Colvin, supra note 13, at 408; see also Alexander J.S. Colvin, Paper Presentation at the 62nd Annual Conference of Labor, New York University, Employment and Consumer Arbitration: What Do the Data Show? (June 5, 2009).

95 Colvin, supra note 13 , at 419.

96 Id. at 430.

97 Id. 
employers. In those cases, the employee win rate was $11.3 \%$ in cases with a repeat-employer arbitrator pair and $14.7 \%$ in the rest of the cases. But the difference was not statistically significant. 98

Overall, the empirical evidence tends to support the existence of a repeatplayer effect, but suggests that the effect may be due to case screening by repeat businesses rather than repeat-arbitrator or repeat-player bias.

\section{AAA CONSUMER ARBITRATION PROCEDURES}

For consumer arbitrations administered by the AAA, the starting point for understanding the arbitration process is the AAA's Supplementary Procedures for Resolution of Consumer-Related Disputes. 99 Under the AAA's rules, a case is classified as a consumer case when it meets three requirements. First, it must arise out of "an agreement between a consumer and a business where the business has a standardized, systematic application of arbitration clauses with customers...."100 Second, "the terms and conditions of the purchase of standardized, consumable goods or services [must be] non-negotiable or primarily non-negotiable in most or all of its terms, conditions, features, or choices."101 Third, "[t]he product or service

98 Id. at $430-31$.

99 American Arbitration Association, Supplementary Procedures for the Resolution of Consumer-Related Disputes (Rules Effective Sept. 15, 2005), http://www.adr. org/sp.asp?id=22014 [hereinafter AAA, Consumer Rules]. In July 2009, the AAA announced that it was imposing a moratorium on its administration of most consumer debt collection arbitrations. See American Arbitration Association, The American Arbitration Association Calls for Reform of Debt Collection Arbitration (July 23, 2009), available at http://www.adr.org/si.asp?id=5769. The moratorium extends to the following cases:

[C]onsumer debt collections programs or bulk filings and individual case filings in which the company is the filing party and the consumer has not agreed to arbitrate at the time of the dispute and the case involves a credit card bill or, the case involves a telecom bill or the case involves a consumer finance matter.

American Arbitration Association, Notice on Consumer Debt Collection Arbitrations, http://www.adr.org/sp.asp?id=36427 (last visited Oct. 27, 2009). The moratorium does not apply to individual claims brought by other creditors (such as law firms and accounting firms) against consumers seeking to recover amounts alleged to be owed, or to cases involving telecom bills, credit card bills, or other consumer finance matters that the parties agree to arbitrate after a dispute has arisen.

100 AAA, Consumer Rules, supra note 99, R. C-1(a).

${ }^{101}$ Id. 


\section{AN EMPIRICAL STUDY OF AAA CONSUMER ARBITRATIONS}

must be for personal or household use." 102 The AAA makes the initial determination of whether a case is a consumer case, subject to redetermination by the arbitrator. ${ }^{103}$

When a case is designated as a consumer case, the AAA's Supplementary Procedures for Resolution of Consumer-Related Disputes generally will apply. ${ }^{104} \mathrm{~A}$ central feature of those procedures is their discounted fee schedule, designed to satisfy the requirement of the Consumer Due Process Protocol that arbitration be available to consumers at a reasonable cost. ${ }^{105}$ For consumer claims administered by the AAA, fees are based on a three-tiered structure. For claims seeking less than $\$ 10,000$, the consumer pays up to $\$ 125.106$ The full amount is applied toward the arbitrator's fees and none to the AAA's administrative fees. For claims seeking between $\$ 10,000$ and $\$ 75,000$, the consumer pays up to $\$ 375.107$ Again, the AAA applies the full amount toward the arbitrator's fees and none to its administrative fees. For claims over $\$ 75,000$, the consumer pays administrative fees based on the regular fee schedule in the AAA Commercial Rules, and arbitrator's fees based on the arbitrator's usual rates, with a deposit of one-half the arbitrator's fee due on filing. ${ }^{108}$ The consumer

102 Id; see also JAMS, The Resolution Experts, Consumer Arbitration Policy: Minimum Standards of Procedural Fairness n.1 (effective July 15, 2009), http://www.jamsadr.com/files/Uploads/Documents/JAMS-

Rules/JAMS_Consumer_Min_Stds-2009.pdf ("These standards are applicable where a company systematically places an arbitration clause in its agreements with individual consumers and there is minimal, if any, negotiation between the parties as to the procedures or other terms of the arbitration clause. A consumer is defined as an individual who seeks or acquires any goods or services primarily for personal family or household purposes.").

103 AAA, Consumer Rules, supra note 99, R. C-1(a) ("The AAA will have the discretion to apply or not to apply the Supplementary Procedures and the parties will be able to bring any disputes concerning the application or non-application to the attention of the arbitrator.").

104 Id.

105 National Consumer Disputes Advisory Committee, Consumer Due Process Protocol, princ. 6 (Apr. 17, 1998), available at http://www.adr.org/sp.asp?id=22019. For a brief description of the fee structure governing cases brought by a single debt buyer under a debt collection arbitration program administered by the AAA, see SEARLE CIVIL JUSTICE INST, supra note 11, at 29 app A.

106 AAA, Consumer Rules, supra note 99, R. C-8 ("Fees and Deposits to be Paid by the Consumer").

107 Id.

$108 I d$. If, however, the arbitration agreement provides for the consumer to pay a 
may seek a deferral or waiver of the administrative fees on a showing of financial hardship and request an arbitrator who is willing to serve pro bono. 109

Under the AAA's rules, the business is responsible for paying all the administrative fees and the remaining arbitrator's fees for small consumer claims, both for claims brought by the consumer as well as claims brought by the business. For claims of $\$ 10,000$ or less, the business pays $\$ 750$ in administrative fees and an additional $\$ 200$ if a hearing is held. ${ }^{110}$ In addition, the business is responsible for the remaining $\$ 125$ in arbitrator's fees. ${ }^{111}$ For claims seeking between $\$ 10,000$ and $\$ 75,000$, the business pays $\$ 950$ in administrative fees and $\$ 300$ if a hearing is held. 112 In addition, the business is responsible for the remaining $\$ 375$ in arbitrator's fees. ${ }^{113}$. For business claims seeking over $\$ 75,000$, the business pays administrative fees based on the regular fee schedule in the AAA Commercial Rules, and arbitrator's fees based on the arbitrator's usual rates. ${ }^{114}$

Beyond the fee structure, a number of other features of the AAA Consumer Rules are also worth noting. Even though the parties have agreed to arbitrate, a party retains the right to seek relief in small claims court

lower share of the costs than otherwise would be applicable, the lower contractual amount controls.

109 American Arbitration Association, Administrative Fee Waivers and Pro Bono Arbitrators, www.adr.org/sp.asp?id=22040 ("Pro Bono Service by Arbitrator") ("A number of arbitrators on the AAA panel have volunteered to serve pro bono for one hearing day on cases where an individual might otherwise be financially unable to pursue his or her rights in the arbitral forum.").

110 AAA, Consumer Rules, supra note 99, R. C-8 ("Fees and Deposits to be Paid by the Business: Administrative Fees"). On January 1, 2010, the AAA updated the fee schedule for consumer arbitrations. See American Arbitration Association, Supplementary Procedures for the Resolution of Consumer-Related Disputes (Fees Effective Sept. 15, 2005), available at http://www.adr.org/sp.asp?id=22014. The fees described in the text are those applicable during the time period we studied.

111 AAA, Consumer Rules, supra note 99, R. C-8 ("Fees and Deposits to be Paid by the Business: Arbitrator Fees").

112 Id. R. C-8 ("Fees and Deposits to be Paid by the Business: Administrative Fees").

113 Id. R. C-8 ("Fees and Deposits to be Paid by the Business: Arbitrator Fees").

${ }_{114}$ Id. R. C-8 ("Fees and Deposits to be Paid by the Business: Administrative Fees"); see American Arbitration Association, Commercial Arbitration Rules and Mediation Procedures, COMM. ARB. R-49 \& R-51 (amended and effective Sept. 1, 2007), available at $\mathrm{http}: / / \mathrm{www}$.adr.org/sp.asp?id=36094 [hereinafter AAA, Commercial Rules]. 
instead. ${ }^{115}$ In most cases, the entire proceeding is to be conducted on an expedited basis. ${ }^{116}$ The AAA appoints the arbitrator from its consumer panel, subject to the parties' right "to submit any factual objections to that arbitrator's service." 117 For claims seeking $\$ 10,000$ or less, the default rule is that the case will be resolved on the basis of documents only. ${ }^{118}$ Either party may request a telephone or in-person hearing, however. ${ }^{119}$ Likewise, the arbitrator may hold a telephone or in-person hearing if he or she decides one is necessary. For claims seeking over $\$ 10,000$, the default rule is that the arbitrator will hold either a telephone or in-person hearing unless the parties agree otherwise. ${ }^{120}$ The arbitrator's award "shall be in writing,"121 and in making the award "[t]he arbitrator may grant any remedy, relief or outcome that the parties could have received in court." 122

\section{RESEARCH METHODOLOGY}

This Part describes the research methodology of this study. It begins by outlining the research questions of interest, and then describes the case file sample and other data sources.

115 AAA, Consumer Rules, supra note 99, R. C-1(d); see Consumer Due Process Protocol, supra note 105, princ. 5.

116 E.g., AAA, Consumer Rules, supra note 99, R. C-1(b) ("The Expedited Procedures will be used unless there are three arbitrators."), C-2(b), C-4, C-6, \& C-7(a); see Consumer Due Process Protocol, supra note 105, princ. 8 ("Reasonable Time Limits").

117 AAA, Consumer Rules, supra note 99, R. C-4; see Consumer Due Process Protocol, supra note 105, princ. 3 ("Independent and Impartial Neutral: Independent Administration") and princ. 4 ("Quality and Competence of Neutrals").

118 AAA, Consumer Rules, supra note 99, R. C-5.

119 Consumer Due Process Protocol, supra note 105, princ. 12 (“Arbitration Hearings").

120 AAA, Consumer Rules, supra note 99, R. C-6.

${ }^{121}$ Id. R. C-7(b); see Consumer Due Process Protocol, supra note 105, princ. 15 ("Arbitration Awards").

122 AAA, Consumer Rules, supra note 99, R. C-7(c); see Consumer Due Process Protocol, supra note 105, princ. 14 ("Arbitral Remedies"). 
A. Research Questions: Costs, Speed, and Outcomes of AAA Consumer Arbitrations

We examine a variety of aspects of the AAA consumer arbitration caseload in this article. Our focus is on the AAA arbitration process itself, rather than on comparing arbitration to litigation.

First, we describe the general characteristics of AAA consumer arbitration cases, as reflected in the case file sample. Which cases are more common - cases brought by consumers or cases brought by businesses? How much do claimants seek? What types of businesses are claimants or respondents in consumer arbitrations? To what extent are cases resolved ex parte-that is, without one party (presumably the consumer) participating? What proportion of arbitration cases are resolved by an award?

Second, we consider the costs of consumer arbitration, in particular the arbitrator's fees and the AAA's administrative fees. The AAA's arbitration rules set out the basic framework, subject to the arbitrator's power to reallocate fees in the award. ${ }^{123}$ To what extent do arbitrators use that power, and how does it affect the amount of arbitrator's fees and administrative costs that are assessed to consumers? Moreover, how does the amount of arbitration fees compare to the amounts sought in arbitration?

Third, we look at the speed of the arbitration process-how long does it take to resolve a case from filing to award? How does the speed of the process compare for consumer claimants and business claimants? How does the speed of the process compare for cases resolved on the basis of documents as opposed to telephone and in-person hearings?

Fourth, we examine various measures of outcomes in arbitration-in particular, consumer and business win rates, compensatory damage awards, and compensatory damage awards as a percentage of the amount claimed. How do consumers and businesses fare in arbitration under each of these measures? To what extent do arbitrators also award attorneys' fees, punitive damages, and interest to prevailing parties? Do outcomes differ in cases in which consumers are represented by an attorney as compared to cases in which they proceed pro se? Is there any evidence of a repeat-player effect, with repeat businesses faring better in arbitration than non-repeat businesses? If so, is the repeat-player effect due to bias in favor of repeat businesses or is it due to case screening by repeat businesses?

123 See supra Part III. 


\section{B. Data \& Methodology}

Our primary dataset, which we refer to as the "case file sample," consists of 301 AAA consumer arbitration cases closed by an award between April 2007 and December 2007.124 The cases in the case file sample were drawn from a broader AAA dataset consisting of all consumer arbitration cases coded as closed from 2005 through 2007 . We reviewed all 313 consumer cases that were awarded from April through December 2007,125 the period for which files were still available under AAA file retention policies. ${ }^{126} \mathrm{We}$ excluded the following cases from the case file sample: two cases from April 2007 for which the files had by accident been prematurely destroyed: one case for which the case file could not be located; two cases that had been reopened; and seven cases that were improperly labeled as awarded consumer cases in the original AAA dataset. The case file sample consists of the remaining 301 cases.

We then coded those cases for approximately 200 variables that describe various aspects of the arbitration process, including: the identity and characteristics of the parties; the identity of the parties' representatives, if any; the AAA office and case manager that administered the case; the type of case and amounts claimed; key dates in the arbitration process; hearing

124 In September 2007, the AAA began administering a program of debt collection arbitrations filed by a single buyer of consumer debt. The first awards under the program were issued in March 2008. This article does not deal with these awards because they were issued after the time period studied. For a preliminary analysis of these cases, see SEARLE CIVIL JUSTICE INST., supra note 11, at 13-20.

125 In addition to these 313 consumer case files, the AAA included in its broader dataset thirty-two cases in which students challenged the cancellation of test scores. Because those cases were different in kind from the other consumer cases in the case file sample, in that they revolved around the cancellation of test scores and involved no claim for damages, we excluded those cases from the case file sample.

126 Under AAA file retention policies, awarded case files are retained for fifteen months after the date the file is closed, and all other case files (e.g., files for settled cases and cases dismissed by the parties) are retained for six months after the date they are closed. The AAA informs parties of these document retention policies in its correspondence notifying them of the closing of the case file. See, e.g., Letter from Elizabeth Cominole, Case Manager, American Arbitration Association to Richard E. Molan \& Mark T. Broth (May 20, 2008), available at http://aaup-unh.org/wpcontent/uploads/2009/02/arbitration.pdf ("[I]t is the AAA's policy to retain awarded cases for a maximum period of fifteen (15) months from the date of the transmittal letter. Therefore, please take note that the above referenced case file will be destroyed 15 months from the date of this letter."). 
information (including the type and location of the hearing); amounts awarded, if any; and the fees paid to the AAA and the arbitrator.

We double-checked our work using the original case files. Finally, we corrected any inconsistencies across and within the variables. Once the data were cleaned, we aggregated variables for multiple parties into single claimant and respondent variables to use in the data analysis below.

The case file sample is subject to several possible selection biases. First, the case file sample is limited to consumer arbitrations administered by the AAA. Arbitrations arising out of clauses that specify other arbitration providers are not included in the case file sample. To the extent providers differ in how they administer cases, or in the types of cases or businesses they attract, the case file sample will not be representative of all consumer arbitrations. In particular, businesses that seek to avoid application of the Consumer Due Process Protocol would presumably be less likely to provide for AAA arbitration. As a result, arbitrations arising out of clauses drafted by such businesses will be less likely to be included in the case file sample.

Second, the case file sample is limited to AAA consumer arbitrations giving rise to an award in the last nine months of 2007. Moreover, due to constraints on the availability of original case files and time constraints in collecting the data, ${ }^{127}$ the time period covered by the cases is not a full calendar year. We know of no reason why awards from the nine months studied would differ from other periods of similar length, and no reason why awards from 2007 would differ from awards in nearby years. One consequence of the time period studied is that it necessarily limits the number of cases in the case file sample.

In addition to the case file sample, when possible, we also used a larger dataset ("AAA consumer dataset") comprising all 3220 AAA consumer cases closed between 2005 and 2007. ${ }^{128}$ The AAA maintains this dataset in the ordinary course of its business, collecting data for its internal purposes on some, but not all, of the variables in which we are interested. Case managers collect and enter the information in the AAA consumer dataset to track case progress and to make sure the parties are charged the correct fees. Because the AAA consumer dataset is used on an ongoing basis, the AAA updates the

127 Our ability to examine older case files was limited by the AAA's document retention policy, described supra note 126 . Our ability to examine newer case files was limited by time and resource constraints in completing data collection for this study.

128 Before using the AAA consumer dataset in this study, we excluded the cases identified in the file review that were not consumer arbitrations or not currently closed, as well as the cases in which students challenged the cancellation of test scores. 
data as case information changes. ${ }^{129}$ Moreover, case managers tend to focus on the information they need to monitor the case. As a result, data central to the AAA's operations, such as the names of the parties, the key dates in the case, and the total fees charged to all parties are more likely to be entered consistently than other data on the case.

Because the AAA consumer dataset was updated by many different case managers at different times, we expected the coding of certain variables to be somewhat inconsistent. To determine the degree of that inconsistency, we compared the data we collected for the 301 cases in the case file sample to the data the AAA maintained for those same 301 cases in the AAA consumer dataset.

Certain information was almost completely consistent between the AAA consumer dataset and the case file sample. For example, distinguishing between businesses and consumers is always possible, which made it reasonably straightforward to identify the type of business involved. Further, cases were consistently coded as either awarded or non-awarded, although it was not possible to verify whether the non-awarded cases were properly coded as settled or withdrawn.

Other information is less accurate, but is still reasonably reliable. Because of the way information was entered into the AAA consumer dataset, it was not always possible to distinguish claimants from respondents. However, in 295 out of the 301 cases $(98.0 \%)$, the claimant was the first listed party and could be reliably identified. In 6 of 301 cases $(2.0 \%)$ we could not correctly categorize the parties as claimants or respondents by using the order of appearance. Further, the key dates seem reasonably accurate. The AAA did not enter the date a case was filed, instead using the date the case was assigned in its system. We could not determine the assignment date in our review of the files, but instead recorded the filing dates. The differences between the filing and assignment dates averaged 5.2 days with a median of 1 day. Although we could not verify the date the AAA administratively closed a case, we were able to determine the award dates. For the cases in the case file sample, the award date entered by the AAA was different from the closed date in 14 cases $(4.7 \%)$. The differences for these 14 cases had a mean of 17.5 days and a median of 1 day. The differences were likely due to minor clerical errors and the fact that, on occasion, a case

129 For example, the recorded information on the case manager responsible for the case was changed whenever a new case manager was assigned to the case. Thus, the name of the case manager recorded in the dataset is the name of the case manager with responsibility for the case at the time the case was closed. 
manager recorded the date of a partial award rather than the date of the final award.

We also find similar accuracy in the identification of claims for $\$ 75,000$ or less and claims of more than $\$ 75,000$. Of the 301 cases, $13(4.3 \%)$ differed in their categorization. Less consistent is the association of exact AAA administrative fee amounts with each party. For the first party, the AAA administrative fees recorded were different 33 out of 301 times $(11.0 \%)$ and for the second party they were different 40 out of 301 times (13.3\%). As mentioned above, the sums of the AAA administrative fees were consistent, however.

Finally, the amount claimed and the amount awarded were much less consistent than the other data we compared. ${ }^{130}$ Specifically, the amount sought by the first party listed in the AAA consumer dataset differed in 59 out of 301 cases $(19.6 \%)$ between the AAA consumer dataset and the case file sample. In many of these cases, it appeared that the parties or the AAA case managers included attorneys' fees, interest, punitive damages, or other damages together with the compensatory damages sought in a single amount claimed. Or it is possible that the case managers entered the amount claimed by a different party. The amount sought by the second party listed (the majority of which were counterclaims) was entered differently in 39 out of 301 cases $(13.0 \%)$. In most of the 301 cases, however, the second party did not assert a claim. In those cases in which the second party did assert a claim, the data were entered differently in 34 out of 48 cases $(70.8 \%)$.

The inconsistencies in award amounts are similar. The amount of compensatory damages awarded to the first party listed differed in 88 out of the 301 cases $(29.2 \%)$ between the AAA consumer dataset and the case file sample. In many of these cases, the parties or the AAA case managers combined the compensatory damages awarded with the amount of attorneys' fees, interest, punitive damages, or other damages awarded. In other cases, the case managers entered the amount awarded to a different party or did not enter the amount awarded at all. The amounts of compensatory damages awarded to the second party listed (the majority of which were from counterclaims) were entered differently in 31 out of 301 cases $(10.3 \%)$. Again, however, in most of the 301 cases the second party did not assert a claim. In those cases in which the second party did assert a claim, the data were entered differently in 30 out of 48 cases $(62.5 \%)$.

130 Since most of the cases in the case file sample only had claims from the first two parties listed, we discuss the results as they relate to the first two parties. 
Our access to all of the sources of data from the AAA is subject to a nondisclosure agreement we entered into with the AAA. The non-disclosure agreement protects the expectations of privacy of the parties to the arbitration in their contractually specified dispute resolution process. As required by the non-disclosure agreement, we report aggregate results about the arbitration process; we do not include any information that might identify a particular case or party.

\section{EMPIRICAL RESULTS: COSTS, SPEED, AND OUTCOMES OF AAA CONSUMER ARBITRATIONS}

This Part sets out our empirical findings, which are based on AAA data from the 301 cases in the case file sample, supplemented when possible with data from the 3220 cases in the AAA consumer dataset. Our findings address the following: (1) general characteristics of the cases in the case file sample; (2) the costs incurred by the parties in arbitrating their case; (3) the speed of the arbitration process; and (4) outcomes of AAA consumer arbitrations, including data on outcomes in cases with pro se consumer claimants and repeat-player businesses.

\section{A. General Case Characteristics}

Because our purpose is to describe comprehensively the AAA's consumer arbitration caseload, this section gives a general overview of case characteristics for the 301 cases in the case file sample, supplemented when possible with data from the AAA consumer dataset.

\section{Business Claimants v. Consumer Claimants}

In the substantial majority of AAA consumer arbitrations, the consumer is the claimant. ${ }^{131}$ Of the cases in the case file sample, consumers were claimants in 240 of 301 (or $79.7 \%$ ) of the cases, while businesses were claimants in 61 of 301 (or $20.3 \%$ ) of the cases. Because we can reasonably rely on the coding accuracy of the AAA consumer dataset for business and consumer claimants, we used this dataset to verify the case file sample for this variable. The results from the AAA consumer dataset are similar.

131 Thus, the AAA's consumer caseload more closely resembles the JAMS consumer caseload than the NAF's caseload, which consists almost exclusively of arbitrations brought by businesses against consumers to collect debts. See supra Part II.C. 
Assuming, based on our data consistency analysis, ${ }^{132}$ that the first named party in that dataset is the claimant, consumers were claimants in 2765 of the 3220 (or $85.9 \%$ ) of the cases, while businesses were claimants in 455 of 3220 (or $14.1 \%$ ) of the cases. Figure 1 shows the similarity between the two data sources.

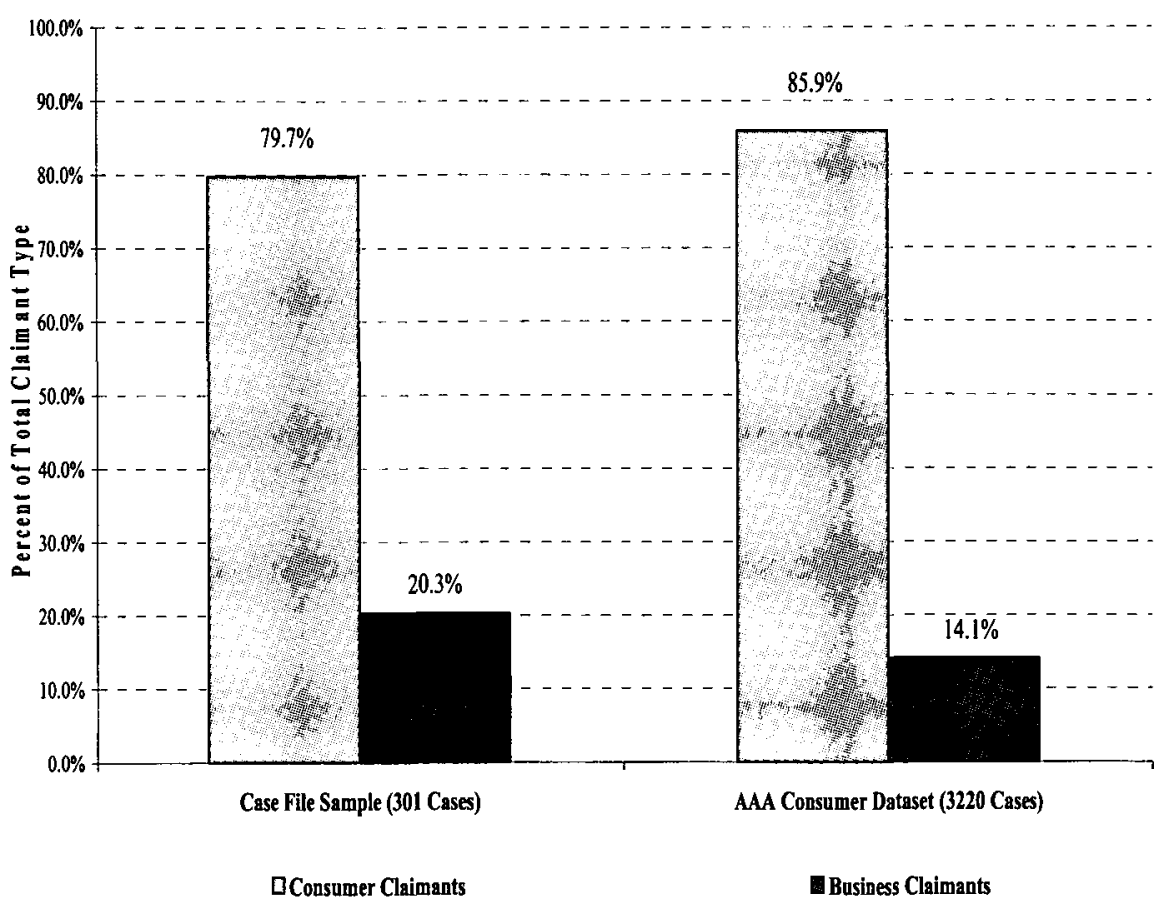

As a general matter, the types of cases brought by businesses in the case file sample differed from the types of cases brought by consumers. In most cases brought by businesses, the business claimants sought payment for goods delivered or services rendered but usually little else. In contrast, the issues raised in cases brought by consumer claimants were more diverse, with consumers asserting claims for non-delivery of goods or services, claims for breach of warranty for defective goods or services, claims under state consumer protection acts, claims under federal consumer protection

132 See supra Part IV.B. 
statutes, and the like. Because of these sorts of differences between the cases, in the rest of our data analysis we examine cases with business claimants separately from cases with consumer claimants.

\section{Amounts Claimed}

The amount sought by the claimant is an important variable for several reasons. First, arbitration fees vary depending on the amount claimed, with low-cost arbitration available under the AAA's consumer rules for claims seeking $\$ 75,000$ or less. Accordingly, in the rest of this analysis we examine cases seeking $\$ 75,000$ or less separately from cases seeking more than $\$ 75,000$. Second, as discussed above, ${ }^{133}$ the extent of the AAA's review of arbitration clauses for compliance with the Due Process Protocol depends on the amount claimed. Third, empirical studies of arbitration outcomes use the amount claimed as a rough proxy for the value of the claim. ${ }^{134}$

But determining the amount claimed turns out to be more difficult than sometimes assumed. ${ }^{135}$ First, claimants sometimes combine various elements of damages into a single claim amount, which includes not only compensatory damages, but also interest, punitive damages, and attorneys' fees. Because the AAA bases its fees only on the amount of compensatory damages claimed, excluding interest, punitive damages, and attorneys' fees, we treat those individual items of damages separately as well. In this section, we include only amounts of compensatory damages sought as the amount claimed. ${ }^{136}$ Moreover, when we categorize results in this Article by the amount claimed-usually in two categories, $\$ 75,000$ or less and more than $\$ 75,000$ - we likewise use the amount of compensatory damages sought in calculating the amount claimed.

Second, although claimants must specify a claim amount in their demand for arbitration, ${ }^{137}$ some claimants specify the claim amount not as a single number but as a range of numbers. ${ }^{138}$ Other claimants specify the amount

133 See supra Part III.

134 See supra Part II.C.

135 E.g., PUblic Citizen, Arbitration Debate TraP, supra note 6, at 12.

136 While claimants often assert a claim for interest, punitive damages, and attorneys' fees in their demand, rarely do they quantify those claims. For further discussion, see infra Part V.D.2.

137 AAA, Consumer Rules, supra note 99, R. C-2(a); AAA, Commercial Rules, supra note 114, R. R-4(a)(i).

138 We discuss here initial claims only, not counterclaims. 
claimed as an inequality, seeking less than or more than a specified amount. For example, a demand for arbitration might claim damages of between $\$ 10,000$ and $\$ 75,000$, or damages greater than $\$ 10,000$. Specifying the amount claimed as a range or inequality ordinarily does not cause problems for the AAA in determining arbitration fees or in its enforcement of the Due Process Protocol because the ranges or inequalities typically are tied to the relevant threshold amounts. ${ }^{139}$ For purposes of using claim amounts in our empirical analysis, however, demands specifying damages as a range or an inequality are much more problematic.

For business claimants, 1 case out of $61(1.6 \%$ of cases) presented the claim amount as an inequality. Consumer claimants, however, were more likely to use inequalities or ranges in their arbitration demand. In 22 cases out of $235^{140}$ ( $9.4 \%$ of cases seeking a monetary amount), consumer claimants presented the claim amount as an inequality (16 of 22) or bounded range (6 of 22).

We considered several options for dealing with demands specifying the claim amount as an inequality or a range. These options included: (1) dropping all cases specifying a claim amount as a range or inequality from the case file sample; (2) taking the midpoint of all ranges (treating inequalities as one end of a range bounded on the other end by the claim threshold); or (3) using the base number of claim amounts specified as inequalities and the midpoint for all claim amounts specified as bounded ranges.

To enhance comparability to the AAA consumer dataset, we used the third option. ${ }^{141}$ For claim amounts given as inequalities, we simply ignored the inequality and used the base amount as the amount of the claim. For example, if the claim amount was written "greater than $\$ 10,000$," we used $\$ 10,000$ as the claim amount; if the claim amount was written "less than $\$ 75,000$," we used $\$ 75,000$ as the claim amount. ${ }^{142}$ For claim amounts given as bounded ranges, we used the midpoint of the range as the claim amount. For example, if the claim amount was written as " $\$ 10,000$ to $\$ 75,000$," we

139 In consumer cases, arbitration fees are a flat amount within certain ranges (less than $\$ 10,000$ and between $\$ 10,000$ and $\$ 75,000$ ), and the threshold for the AAA's administrative review of clauses for protocol compliance is $\$ 75,000$.

140 We excluded the five cases seeking non-monetary remedies from these calculations.

${ }^{141}$ The AAA uses the base amount of the inequality in its consumer dataset.

142 Selecting the lower end of the range in cases not specifying the claim amount will increase the recovery rate discussed below, but the effect should be minimal due to the small number of cases affected by this choice. 
used $\$ 42,500$ as the claim amount. Because only 16 cases with consumer claimants had claim amounts specified as inequalities and only 6 cases had claim amounts specified as bounded ranges, the choice among the options for measuring claim amount rarely affected the results. ${ }^{143}$

Overall, most of the cases in the case file sample involved claims for $\$ 75,000$ or less. For business claimants, $95.1 \%$ of cases (58 of 61) involved claims for $\$ 75,000$ or less. For consumer claimants, $91.5 \%$ of cases ( 215 of 235 ) involved claims for $\$ 75,000$ or less, and $39.1 \%$ of cases (92 of 235) involved claims for less than $\$ 10,000$.

Because the coding of claims as greater than $\$ 75,000$ and less than or equal to $\$ 75,000$ in the AAA consumer dataset is reasonably reliable, we used that dataset to check these results from the case file sample. Again, the findings are similar. In the AAA consumer dataset, excluding non-monetary and unspecified claims, $94.5 \%$ of business claimants brought claims of $\$ 75,000$ or less (359 of 380 cases). By comparison, $88.5 \%$ of consumer claimants brought claims of $\$ 75,000$ or less (2190 of 2475 cases).

Consumers tend to seek larger amounts than businesses in AAA consumer arbitrations. The average claim for business claimants in the case file sample was $\$ 22,037$ and the average claim for consumer claimants was $\$ 46,131$, a statistically significant difference. ${ }^{144}$ There also is a statistically significant difference in the variance of claim amounts between the two groups. ${ }^{145}$ Figure 2, a frequency distribution with equally distributed bins, shows that almost all business claims fall between $\$ 178$ and $\$ 70,756$, with a short tail. Almost all consumer claims also fall between $\$ 178$ and $\$ 70,756$. However, at least 12 cases fell outside that range, including one claim for $\$ 1,200,000$. Thus, consumer claims have a longer tail than business claims.

143 Option 1 resulted in higher average claim amounts than either option 2 or option 3. Further, using option 2 rather than option 3 resulted in an average difference of less than $\$ 100$ for both business and consumer claimants. The claim amount changes for 1 case with a business claimant and 16 cases with consumer claimants between options 2 and 3.

144 We used a two-group t-test for averages in claims made by business claimants and consumer claimants excluding non-monetary claims and adjusting for unequal variances. The $t$-statistic was $-2.9338(D F=290.932$ and $p=0.0036)$, allowing us to reject the null hypothesis that the averages between the two groups were the same.

$145 \mathrm{We}$ used a two-group F-test for variances in claims made by business claimants and consumer claimants excluding non-monetary claims. The f-statistic was 0.0504 (DF $=60,234$ and $p=0.0000$ ), allowing us to reject the null hypothesis that the variances between the two groups were the same. 
Figure 2:

Frequency of Amounts Claimed by Consumer and Business Claimants

(Cases $=290$ )

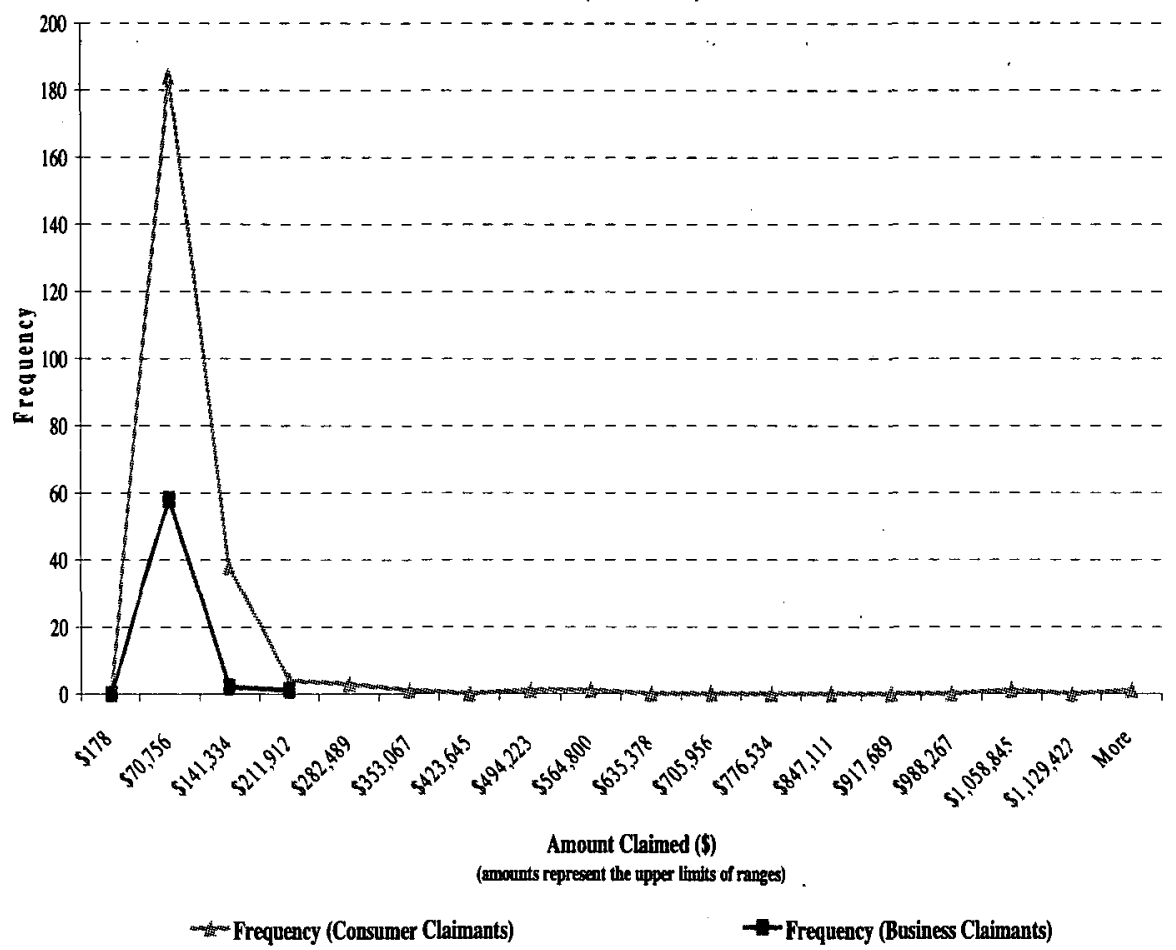

Because the case file sample includes only awarded cases, it is possible that there are differences in claim amounts between awarded cases and other types of closed cases. In order to test whether case resolution was related to claim amounts, we added 46 business cases and 345 consumer cases to the case file sample. ${ }^{146}$ The additional cases represent all cases with monetary claims that were closed between April 2007 and December 2007 in the AAA consumer dataset. Because the case file sample comprised almost all of the awarded cases in this time period, the added cases were mostly settled, withdrawn, or closed in some other way.

146 We note that the individual claim amounts coded in the AAA consumer dataset are less reliable than the binary coding for claims of $\$ 75,000$ or less and claims greater than $\$ 75,000$. See supra Part IV.B. 
For business claimants, the average claim was $\$ 22,037$ for the awarded cases in the case file sample and $\$ 18,313$ for all other cases; the difference in the means is not statistically significant. ${ }^{147}$ Claim amounts for consumer claimants are similar. The average claim was $\$ 46,131$ for the awarded cases in the case file sample and $\$ 66,367$ for all other closed cases. Although the other closed cases had a slightly higher average claim, the difference between the two groups is not statistically significant. ${ }^{148}$

Counterclaims were somewhat rare in the case file sample - only 57 out of 301 cases $(18.9 \%)$ involved a counterclaim. Eleven consumer respondents brought counterclaims: 5 sought compensatory damages of $\$ 75,000$ or less, 2 sought more than $\$ 75,000$, and the remaining 4 sought non-monetary relief or the remedy sought was unspecified. Business respondents were more likely to bring a counterclaim. The remaining 46 counterclaims were brought by business respondents: 33 sought compensatory damages of $\$ 75,000$ or less, 1 sought more than $\$ 75,000$, and the remaining 12 sought non-monetary relief or the remedy sought was unspecified. Counterclaims were not recorded consistently in the AAA consumer dataset so a comparison was not possible.

\section{Types of Businesses}

The types of businesses involved in the cases in the case file sample included: motor vehicle dealerships, credit card issuers, insurance companies, home builders, finance companies, mobile home dealers, and real estate brokers. As shown in Figure 3, the types of companies that were claimants differed from the types of companies that were respondents. Business claimants were mostly service providers: home builders (13 of 61 , or $21.3 \%$ of the cases), real estate brokers ( 12 of 61 , or $19.7 \%$ of the cases), and other service providers such as law and accounting firms ( 20 of 61 , or $32.8 \%$ of the cases). In contrast, the most common business respondents were motor vehicle dealerships ( 66 of 240 , or $27.5 \%$ of the cases) and insurance/warranty

147 The two-group t-test accounting for unequal variances resulted in $t=-0.9056$ $(\mathrm{DF}=102.497$ and $\mathrm{p}=0.3673$ ). The variances between the two groups are significantly different however. The f-statistic was $0.4083(\mathrm{DF}=45,60$ and $\mathrm{p}=0.0021$ ), allowing us to reject the null hypothesis that the variances between the two groups were the same.

148 The two-group t-test accounting for unequal variances resulted in $t=1.0948$ (DF $=466.817$ and $\mathrm{p}=0.2741$ ). The variances between the two groups are significantly different, however, owing to several large claims in cases that were eventually settled. The f-statistic was $7.4138(\mathrm{DF}=344,234$ and $p=0.0000)$, allowing us to reject the null hypothesis that the variances between the two groups were the same. 
companies ( 44 of 240 , or $18.3 \%$ of the cases). The differing types of businesses reflect the different nature of cases brought by business and consumer claimants. Businesses were mostly looking to collect fees owed for services performed while consumers were bringing claims for faulty cars and faulty products, among others.

Figure 3:

Business Types as a Percent of Total Business Respondents and Total Business Claimants (Cases $\mathbf{3 0 1}$ )

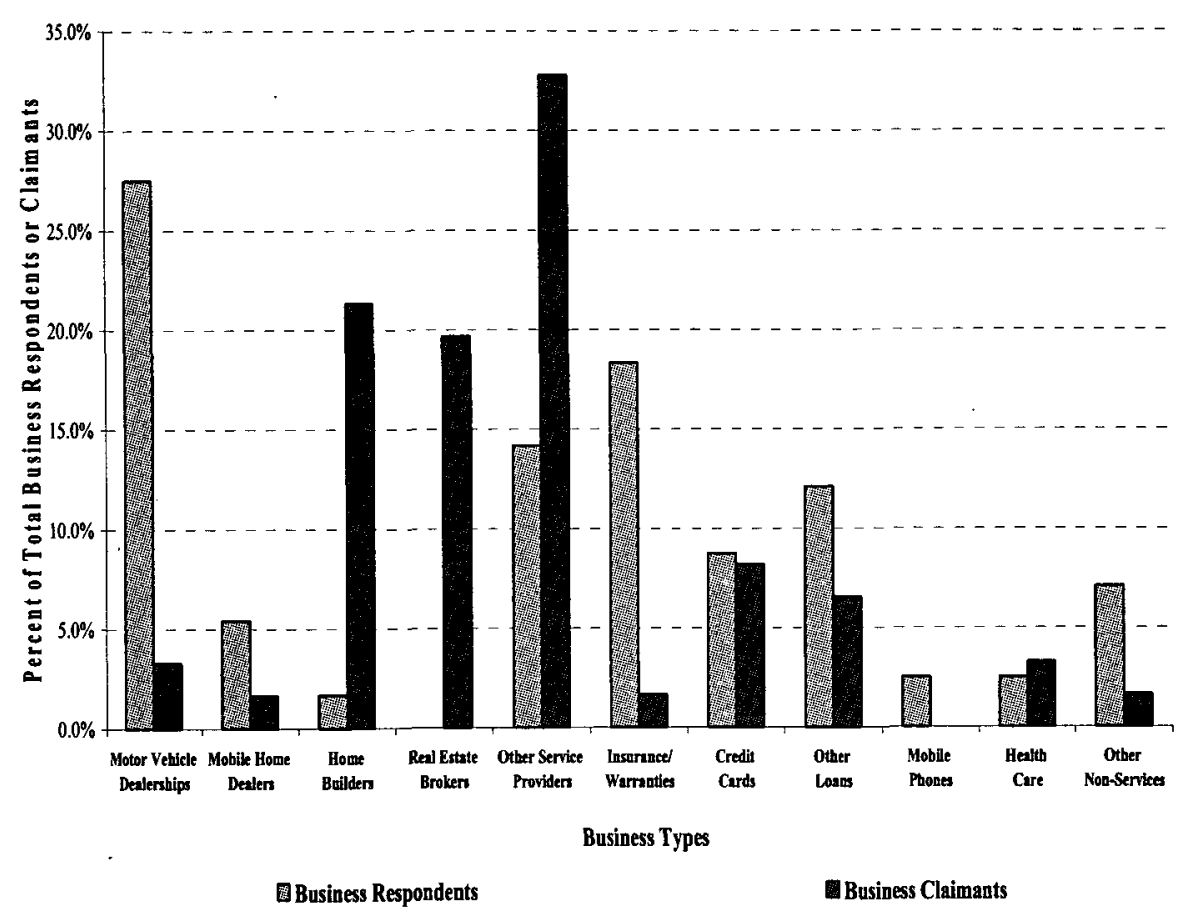

The entries for business type in the AAA consumer dataset are less reliable than for the case file sample. However, we generally found the same business types for business claimants and respondents in both datasets. Business claimants were mostly service providers: home builders ( 59 of 455 , or $13.0 \%$ of cases), real estate brokers (53 of 455 , or $11.6 \%$ of cases), and other service providers such as law and accounting firms (84 of 455, or $18.5 \%$ of cases). Common types of business respondents were motor vehicle dealerships (451 of 2765 , or $16.3 \%$ of cases) and insurance/warranty companies ( 207 of 2765 , or $7.5 \%$ of cases). Note that in the AAA consumer dataset, the type of business as a percentage of the total was generally lower than in the case file sample. This is mostly due to a higher proportion of 
cases involving credit card issuers and other creditors in the AAA consumer dataset, most of which were closed prior to an award.

\section{Ex Parte Proceedings}

Of the 301 cases in the case file sample, 26 cases $(8.6 \%)$ were resolved on an ex parte basis - that is, they were resolved in the absence of one of the parties. All 26 cases involved claims of $\$ 75,000$ or less, and in all 26 cases the absent party was the consumer. Interestingly, however, not all of the ex parte cases involved a business claimant. Twenty-two of the ex parte cases were brought by business claimants. The remaining four cases were brought against businesses by consumers who then either did not appear at the hearing or did not submit documents. Three of the four consumers originally were represented by counsel, who filed the claim but then withdrew from representing the consumer. Ex parte cases were not recorded in the AAA consumer dataset, so a comparison was not possible. ${ }^{149}$

\section{Case Resolutions-Awarded Versus Non-Awarded}

The case file sample is limited to awarded cases, so to examine the frequency of other case resolutions and the relative frequency of awarded cases we used the AAA consumer dataset. The AAA consumer dataset consistently categorizes cases into awarded and non-awarded categories.

In cases involving business claimants, 227 (or 49.9\%) were resolved by an award and 228 (or 50.1\%) were closed but non-awarded. ${ }^{150}$ of the 227 awarded cases, 214 had claims of $\$ 75,000$ or less, 9 had claims of more than $\$ 75,000$, and 4 sought non-monetary relief or an unspecified remedy. Of the 228 non-awarded cases, 145 had claims of $\$ 75,000$ or less, 12 had claims of more than $\$ 75,000$, and 71 sought non-monetary relief or an unspecified remedy.

In cases involving consumer claimants, 887 (or $32.1 \%$ ) were resolved by an award and 1878 (or $67.9 \%$ ) were otherwise closed. Of the 887 awarded cases, 57 had claims of more than $\$ 75,000,793$ had claims of $\$ 75,000$ or

149 As discussed infra Part V.D.2, the number of ex parte awards is likely related to the win rate for business claimants.

150 The AAA database does distinguish among withdrawn, settled, and administratively closed cases. However these distinctions are not always accurate because the AAA relies on the parties to report a settlement or withdrawal. As such, we distinguished only between awarded and non-awarded cases in our analysis. 
less, and 37 sought non-monetary relief or an unspecified remedy. Of the 1878 non-awarded cases, 228 had claims greater than $\$ 75,000,1397$ had claims of $\$ 75,000$ or less, and 253 sought non-monetary relief or an unspecified remedy. Figure 4 below shows the relative differences between case dispositions by amount claimed.

Figure 4:

Percent of Awarded and Non-Awarded Cases by Claimant Type and Amount Claimed

$($ Cases $=3220)$

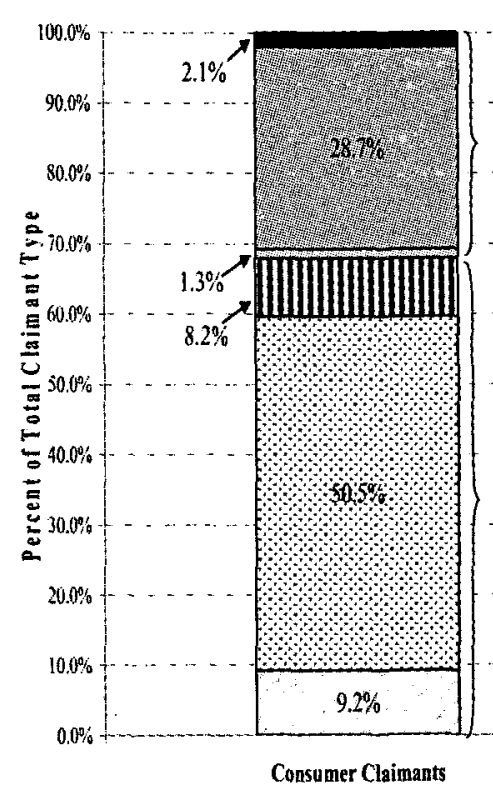

aNon-Awarded (Non-MonetarylUndiscloscd) BNon-Awarded $(\leq \$ 75,000)$

T. Awarded (Non-Monetary/Lindisclosed)

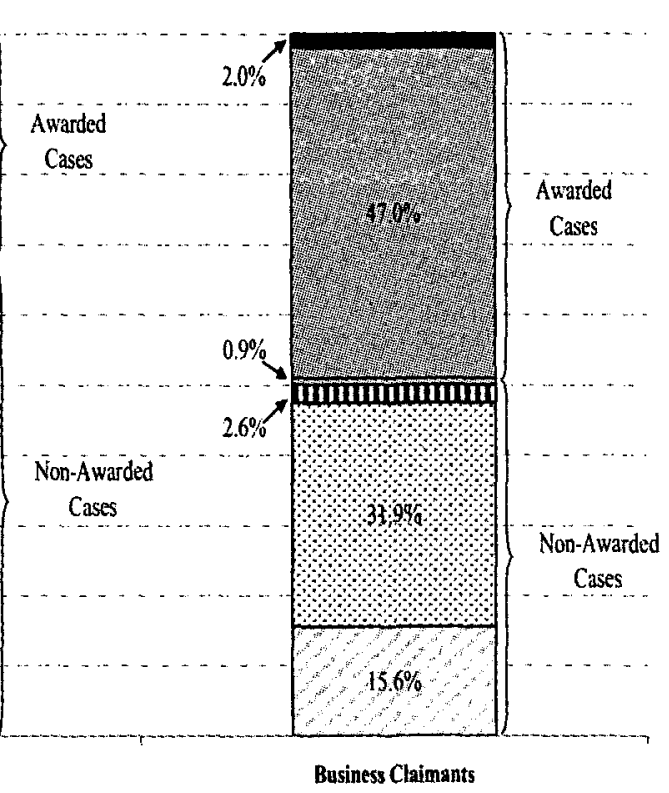

DNon-Awarded $(>\$ 7,000)$

A Awarded $(>\$ 75,000)$

Using the key dates, which were reliably recorded in the AAA consumer dataset, we were also able to estimate how far in the arbitration process cases progressed before being resolved. We categorized the procedural stages using the Assignment Date (the date the case was entered into the AAA's system), the Arbitrator Assignment Date (the date an arbitrator was appointed), Hearing Dates (the date or dates of any hearings, including preliminary hearings), the Hearing Closed Date (the date the hearing, if any, was declared closed), and the Award Date (the date of the award). Cases were categorized by the last listed date in the database before the case was closed. For business claimants, $26.2 \%$ (119 out of 455$)$ of the cases were 
closed before an arbitrator was appointed; for consumer claimants, the percentage was similar ( 766 out of 2765 , or $27.7 \%$ of cases). But cases with consumer claimants were much less likely than cases with business claimants to be resolved by an award. Figure 5 shows the comparison in case progression between consumer and business claimants. ${ }^{151}$

Figure 5:

Cumulative Percent of All Cases by Procedural Stage by Claimant Type

$($ Cases $=3220)$

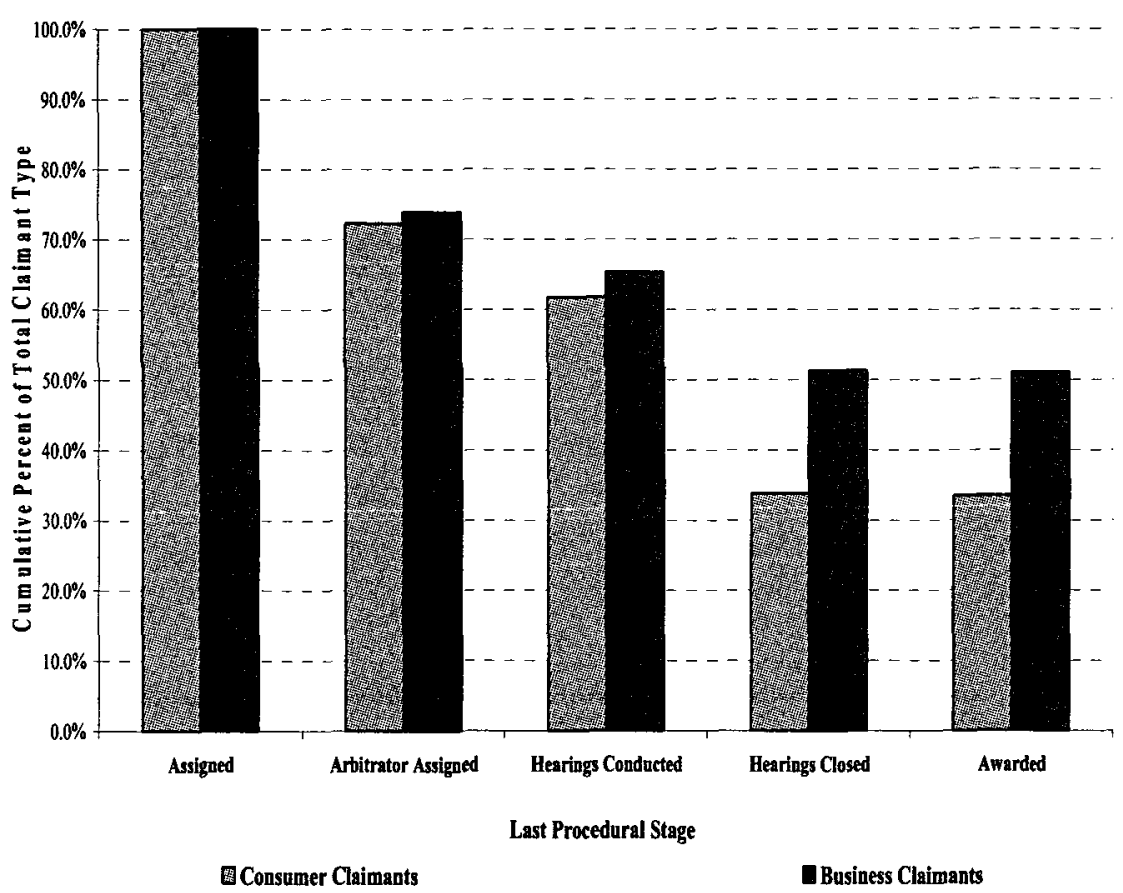

B. Cost of AAA Consumer Arbitrations

As described above, ${ }^{152}$ the AAA has a tiered fee structure based on the amount of compensatory damages claimed. ${ }^{153}$ The fees are not based on

151 We note that a small number of cases $(1.1 \%$ of cases with business claimants and $1.4 \%$ of cases with consumer claimants) have awarded dates but are categorized in the AAA consumer dataset as settled or otherwise closed. We do not have an explanation for this seeming discrepancy. It does not, however, materially affect our findings.

152 See supra Part III.

153 AAA, Consumer Rules, supra note 99, R. C-8. 
other amounts such as punitive damages, interest, or attorneys' fees. ${ }^{154}$ Table 1 summarizes the AAA's fees for consumer cases.

Table 1: AAA Consumer Arbitration Fees

\begin{tabular}{|c|c|c|}
\hline dmount Clained & Fees Owed By Consumer & Fees Owed By Business \\
\hline$<\$ 10,000$ & - Half of arbitrator's fees up to $\$ 125$ & $\begin{array}{l}\text { - } \$ 750 \text { in AAA administrative fees } \\
\text { - } \$ 200 \text { in Case Service Fees if a hearing is held } \\
\text { - Remaining arbitrator's fees (usually } \$ 125 \text { ) }\end{array}$ \\
\hline$\$ 10,000-\$ 75,000$ & - Half of arbitrator's fees up to $\$ 375$ & $\begin{array}{l}\text { - } \$ 950 \text { in AAA administrative fees } \\
\text { - } \$ 300 \text { in Case Service Fees if a hearing is held } \\
\text { - Remaining arbitrator's fees (usually } \$ 375 \text { ) }\end{array}$ \\
\hline $\begin{array}{c}>\$ 75,000 \\
\text { (or Non-Monetary) }\end{array}$ & $\begin{array}{l}\text {-AAA administrative fees according to the } \\
\text { Commercial Fee Schedule } \\
\text { - Half of arbitrator's fees at usual rates }\end{array}$ & $\begin{array}{l}\text {-AAA administrative fees according to the } \\
\text { Commercial Fee Schedule } \\
\text { - Remaining arbitrator's fees at usual rates }\end{array}$ \\
\hline
\end{tabular}

This section describes the amount of arbitration fees assessed, how these fees are allocated in AAA consumer arbitrations, and how arbitration fees relate to the amount sought in cases in the case file sample. We have data on arbitrator's fees and the AAA's administrative fees, but we do not have comparable data on amounts the parties may have paid to their own attorneys. ${ }^{155} \mathrm{We}$ do not provide comparisons to the AAA consumer dataset in this section because we were unable to break down the data in analogous ways.

\section{Fees Assessed to Consumers and Businesses}

The AAA fee schedule and fee allocations by arbitrators in awards determine the total amount of fees assessed to consumers and businesses. ${ }^{156}$

154 Id.

155 Although Elizabeth Hill used awards of attorneys' fees as a proxy for attorneys' fees paid by the parties (see Hill, Due Process, supra note 89, at 798-99) we do not believe we have enough data to make reliable statements regarding attorneys' fees paid by the parties in the case file sample. For further discussion of attorneys' fee awards, see infra Part V.D.2.

156 In addition, contract provisions on occasion provide that consumers are to pay a 
In this section, we summarize the total amounts of administrative and arbitrator's fees assessed to consumers and businesses as well as their respective shares of those fees in the case file sample. ${ }^{157}$

In cases with business claimants, the business is assessed an average of $\$ 958$ in AAA administrative fees and $\$ 751$ in arbitrator's fees, as shown in Figure 6. In these same cases, consumers are assessed an average of $\$ 215$ in AAA administrative fees and $\$ 256$ in arbitrator's fees. Thus, on average, consumer respondents are responsible for $18.3 \%$ of total AAA administrative fees and $25.4 \%$ of total arbitrator fees in those cases. At the tail of the distribution, three consumer respondents were assessed AAA administrative or arbitrator fees in excess of $\$ 1000$. All three brought counterclaims of $\$ 75,000$ or more.

In cases with consumer claimants, the consumer is assessed an average of $\$ 129$ in AAA administrative fees and $\$ 247$ in arbitrator fees, as shown in Figure 6. In these same cases, businesses are assessed an average of $\$ 1161$ in AAA administrative fees and $\$ 1099$ in arbitrator's fees. Thus, on average consumer claimants are responsible for $10.0 \%$ of total AAA administrative fees and $18.4 \%$ of total arbitrator's fees in those cases. Note that these amounts include fees from cases with claims over $\$ 75,000$, so we would expect that, on average, consumers would pay some AAA administrative fees. ${ }^{158}$ At the tail of the distribution, ten consumer claimants were assessed AAA administrative or arbitrator fees in excess of $\$ 1000$. All but one brought claims of $\$ 75,000$ or more.

Overall, consumers are responsible for a larger share of AAA administrative and arbitrator's fees when they are respondents, but never more than approximately one-fourth of the total.

lower fee than set out in the AAA fee schedule.

157 We describe the fees as "assessed" to businesses and consumers because the parties did not necessarily pay the fees as assessed. Further, we do not have systematic data on the extent to which consumers received fee waivers or deferrals from the AAA, and so we report no results on that issue.

158 See supra Part III. 


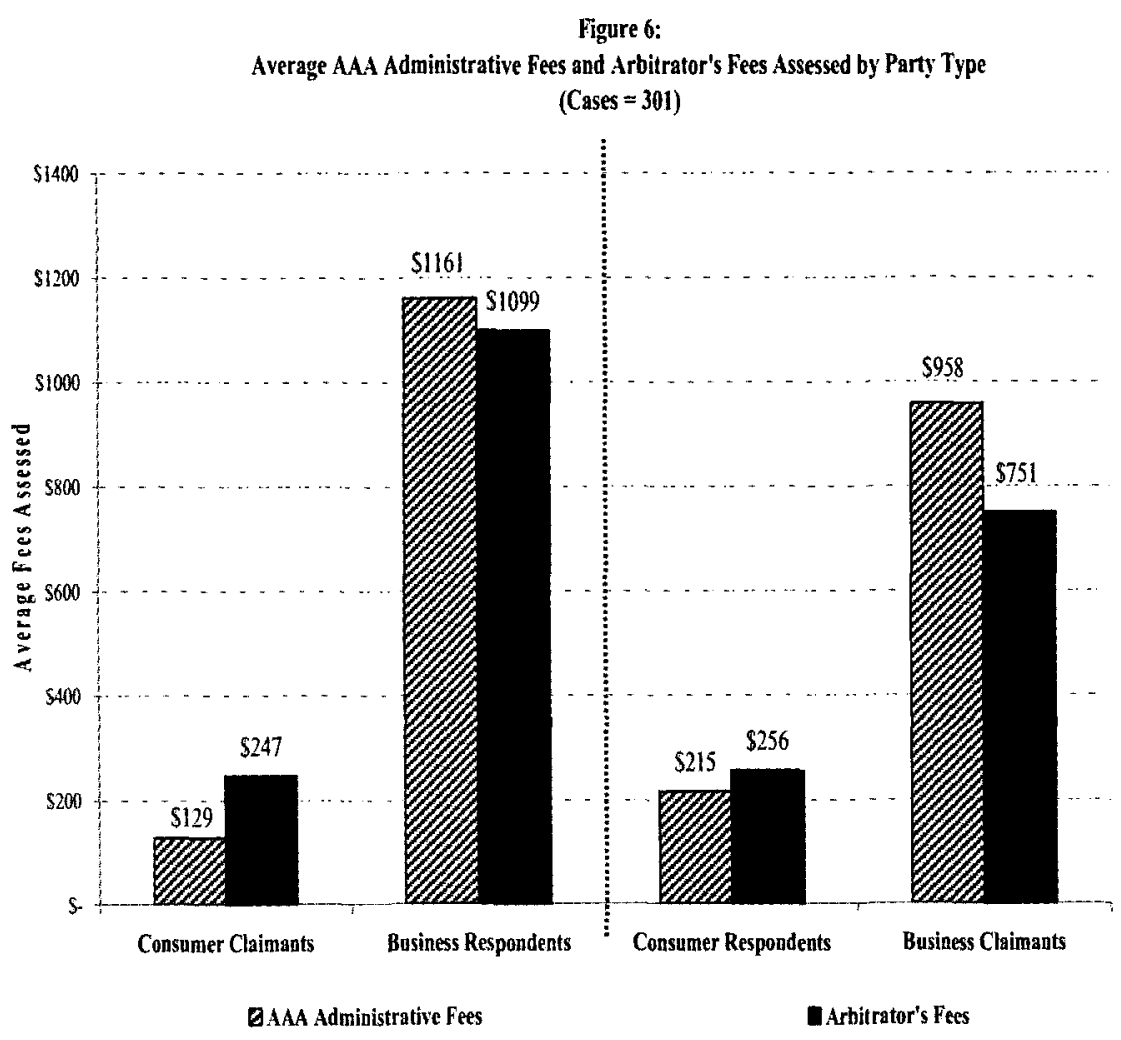

If we break down the fees assessed to consumers and businesses by claim size, using the categories used by the AAA in determining fees, we find that consumer claimants on average are assessed less than the amount specified by the fee schedule. By comparison, consumer respondents are assessed more on average, but this is mostly due to the fact that in a few cases the arbitrator allocated all of the fees to the consumer respondent. ${ }^{159}$

In cases with claims of less than $\$ 10,000$, consumer claimants are assessed on average $\$ 1$ in AAA administrative fees (or $0.1 \%$ of the total); ${ }^{160}$ for cases with claims between $\$ 10,000$ and $\$ 75,000$ they are assessed on

159 See infra Part V.B.2.

160 There is one case with a claim under $\$ 10,000$ for which a consumer was assessed AAA administrative fees, even though the AAA rules do not provide for administrative fees to be assessed to the consumer in such a case. The fees were allocated "as incurred" by the arbitrator after an in-person hearing, but it is not clear from the file why the consumer was assessed these fees. 
average $\$ 15$ (or $1.2 \%$ of the total); ${ }^{161}$ and for cases with claims greater than $\$ 75,000$ they are assessed on average $\$ 1448$ (or $38.6 \%$ of the total).

Further, consumer claimants pay on average $\$ 95$ in arbitrator's fees (or $23.4 \%$ of the total) in cases seeking less than $\$ 10,000$, noticeably less than the $\$ 125$ in arbitrator's fees charged under the AAA fee schedule. ${ }^{162}$ In cases with claims between $\$ 10,000$ and $\$ 75,000$, consumer claimants are assessed on average \$204 in arbitrator's fees (or $16.9 \%$ of the total), again, substantially below the $\$ 375$ charged under the AAA fee schedule. ${ }^{163}$ Finally, in cases with claims greater than $\$ 75,000$, consumer claimants are assessed on average $\$ 1256$ in arbitrator's fees (or $18.8 \%$ of the total). Figure 7 summarizes these findings.

161 There are three cases with claims between $\$ 10,000$ and $\$ 75,000$ for which a consumer was assessed AAA administrative fees. In all three cases, the arbitrator allocated the AAA administrative fees equally between the parties in the award.

162 See supra Part III. This is largely due to the fact that in twenty-one cases $(22.8 \%$ of the time), the arbitrators allocated arbitrator's fees to the business respondent in the award.

${ }^{163}$ See supra Part III. This is largely due to the fact that in forty-seven cases $(38.2 \%$ of the time), the arbitrators allocated arbitrator's fees to the business respondent in the award. 
Figure 7:

Average Fees Assessed to Consumer Claimants by Amount Claimed

(Cases $=\mathbf{2 3 5}$ )

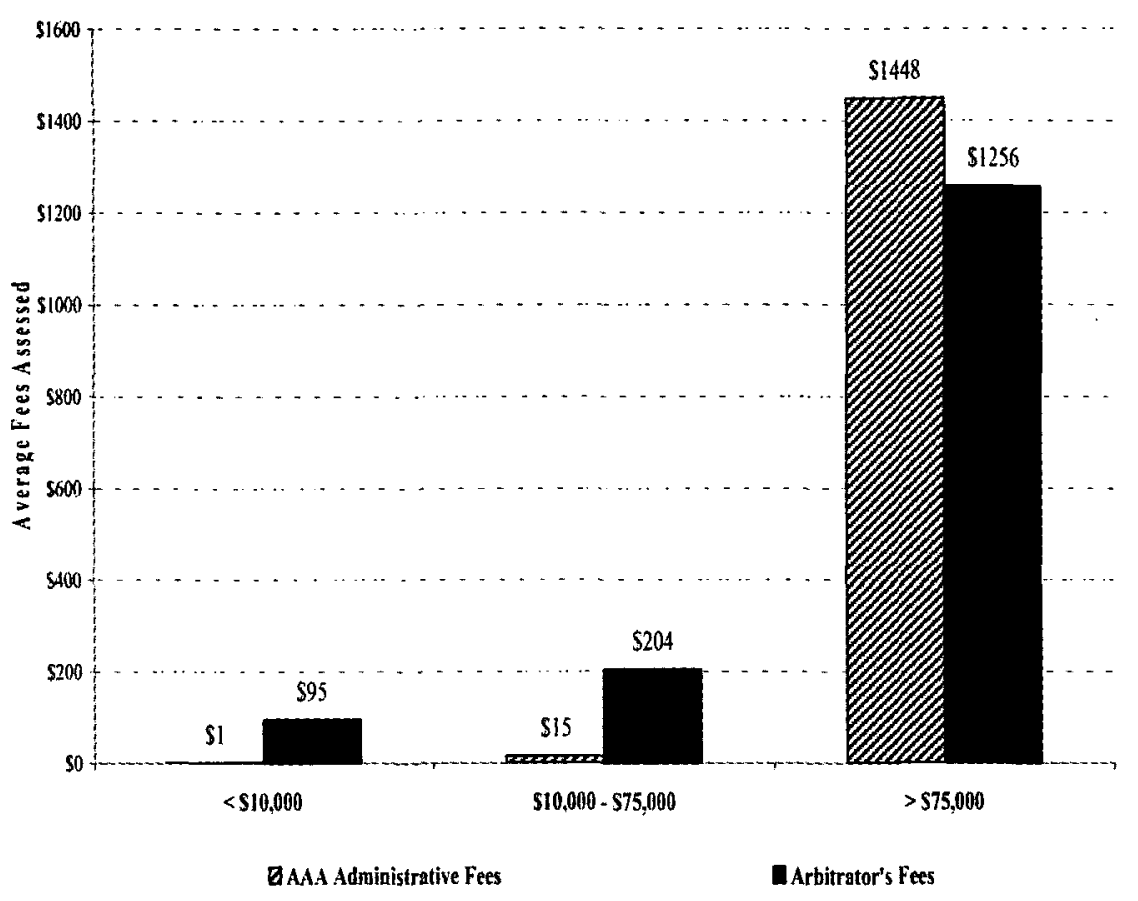

Consumer respondents were generally assessed higher fees on average than consumer claimants, as shown in Figure 8. On average, consumer respondents were assessed \$250 in AAA administrative fees and \$279 in arbitrator's fees for cases with claims less than $\$ 10,000$. These average fees are influenced by a single case in which the consumer respondent asserted a counterclaim for over $\$ 75,000$, and was assessed over $\$ 8000$ in total arbitration fees. Excluding that outlier, consumer respondents were assessed on average $\$ 71$ in AAA administrative fees and $\$ 100$ in arbitrator's fees for cases with claims of less than $\$ 10,000$. For cases with claims between $\$ 10,000$ and $\$ 75,000$, on average consumer respondents were assessed $\$ 65$ in AAA administrative fees and $\$ 111$ in arbitrator's fees. ${ }^{164}$ Finally, for cases

164 In ten cases $(27.8 \%$ of the time) arbitrators allocated arbitrator's fees to consumer respondents equally, partially, or solely. 
with claims greater than $\$ 75,000$, on average consumer respondents were assessed \$1767 in AAA administrative fees and \$1822 in arbitrator's fees.

Figure 8:

Average Fees Assessed to Consumer Respondents by Amount Claimed

(Cases $=61)$

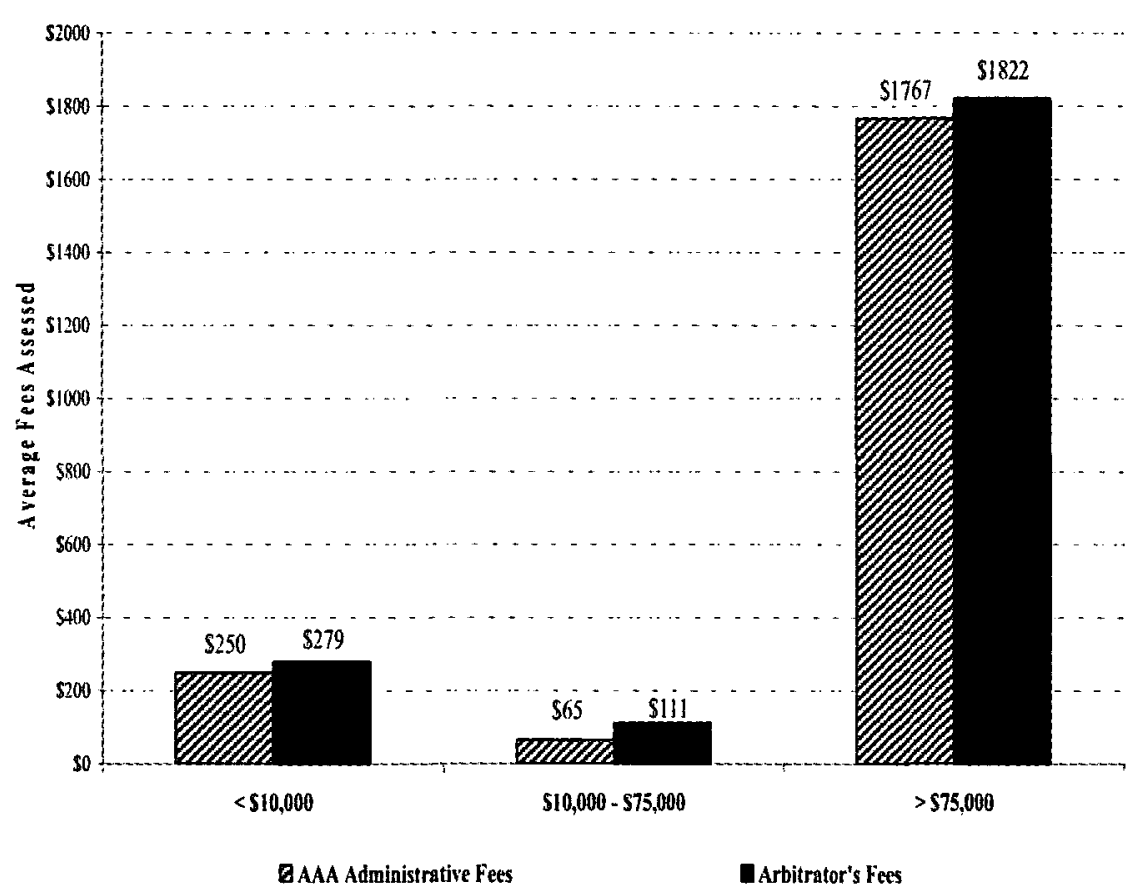

Because we were unable to obtain data on the financial situation of individual consumer claimants, we could not evaluate how affordable these costs of arbitration are to consumers. Of course, all of the cases in the case file sample are ones in which the consumer was able to bring the case; thus, arbitration costs did not preclude the consumer from asserting his or her claim.

2. Fee Allocations in Awards

As discussed in the previous subsection, the fees assessed to a party are determined in part by how the arbitrator allocates fees in the award. Under the AAA's rules, the arbitrator has the power to apportion the AAA's 
administrative fees and arbitrator's fees among the parties in the award as he or she deems appropriate. ${ }^{165}$ Arbitrators can direct that fees be borne "as incurred," specify that fees be shared equally by the parties, or require one party to bear most or all of the fees. The arbitrator has discretion to allocate administrative fees in the same or a different manner from the arbitrator's fees.

In the majority of the 301 cases in the case file sample, the arbitrator directed that fees be borne as incurred. For business claimants, the award provided that AAA administrative fees be borne as incurred in $55.7 \%$ of the cases and that arbitrator's fees be borne as incurred in $42.6 \%$ of the cases. Of the remaining cases with business claimants, AAA administrative fees were allocated solely to the business $36.1 \%$ of the time and solely to the consumer respondent $8.2 \%$ of the time (five cases) ${ }^{166}$ Likewise, arbitrator's fees were allocated solely to the business $18.0 \%$ of the time, allocated equally or disproportionately to the business $31.2 \%$ of the time, and allocated solely to the consumer $8.2 \%$ of the time. ${ }^{167}$

For consumer claimants, fee allocations in awards varied depending on the amount sought - that is, whether the case was subject to the AAA's lowcost arbitration procedures. Specifically, AAA administrative fees were allocated solely to consumer claimants twice; both were in cases with claims seeking over $\$ 75,000$. Arbitrators allocated AAA administrative fees equally or partially to consumers another eight times. Otherwise, arbitrators allocated AAA fees as incurred or solely to the business as shown in Figure 9.

165 AAA, Commercial Rules, supra note 114, R. R-43(c).

166 It is not clear why the arbitrator allocated all AAA administrative fees to the consumer respondents in these five cases, but in two cases the consumers did bring counterclaims.

167 The same five cases allocated both AAA administrative fees and arbitrator's fees solely to the consumers. 


\section{AN EMPIRICAL STUDY OF AAA CONSUMER ARBITRATIONS}

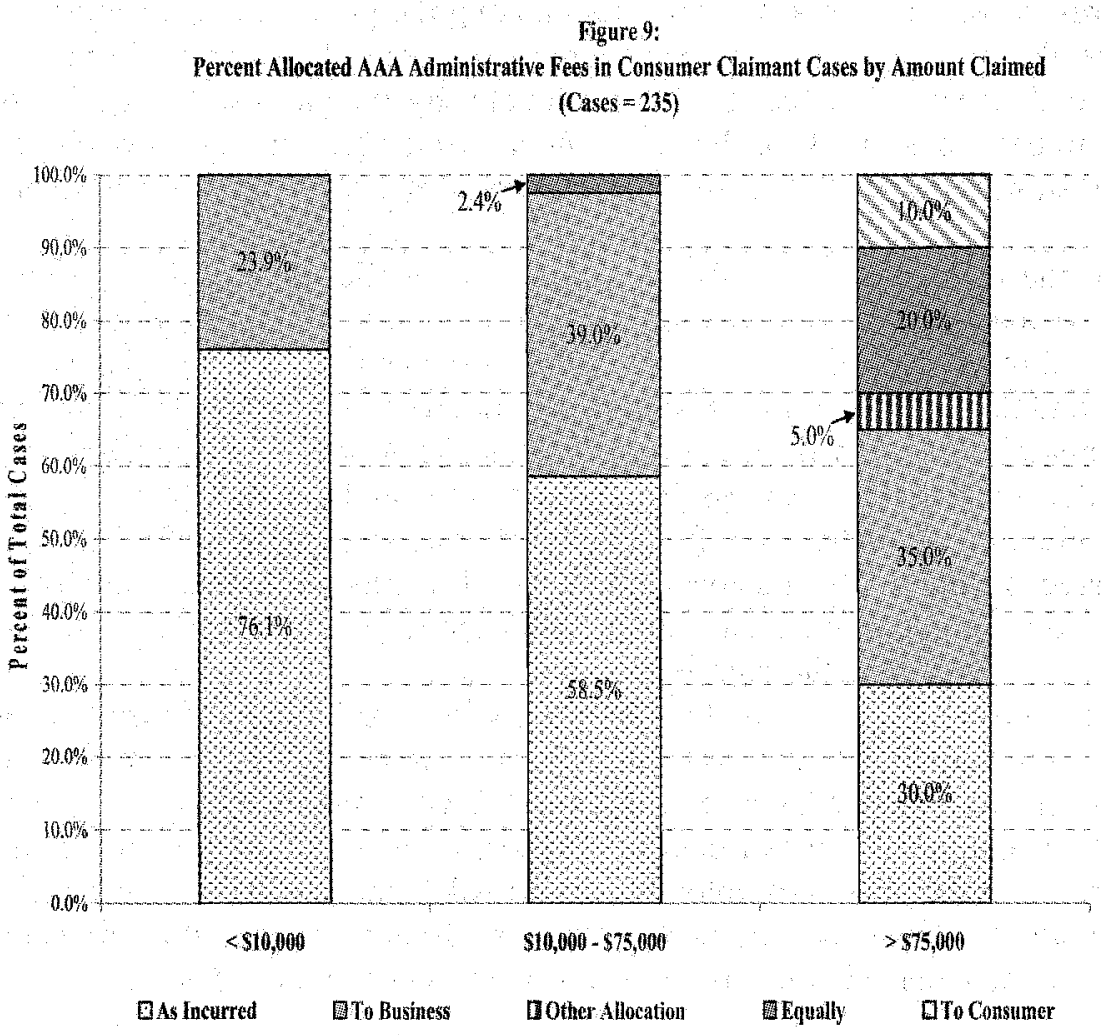

The allocation of arbitrator's fees for cases with consumer claimants was similar to the allocation of AAA administrative fees. In the two cases in which the arbitrator allocated AAA administrative fees to the consumer, the arbitrator also allocated arbitrator's fees to the consumer. In twenty-two cases the arbitrator allocated the arbitrator's fees equally or partially to the consumer, while in another 137 cases the arbitrator ordered the arbitrator's fees to be borne as incurred. ${ }^{168}$ In the remaining seventy-nine cases, the arbitrator allocated arbitrator's fees solely to the businesses. Figure 10 shows

168 Consumers must pay half of the arbitrator's fees under the AAA's low-cost arbitration rules. See supra Part III. An award providing that arbitrator's fees be borne as incurred has the effect of maintaining that original allocation. An award providing that the consumer share the arbitrator's fees with the business equally likely has that same effect as well. 
the arbitrator's fees owed by consumer claimants, broken down by type of claim.

Figure 10:

Percent Allocated Arbitrator's Fees in Consumer Claimant Cases by Amount Claimed

(Cases $=235$ )

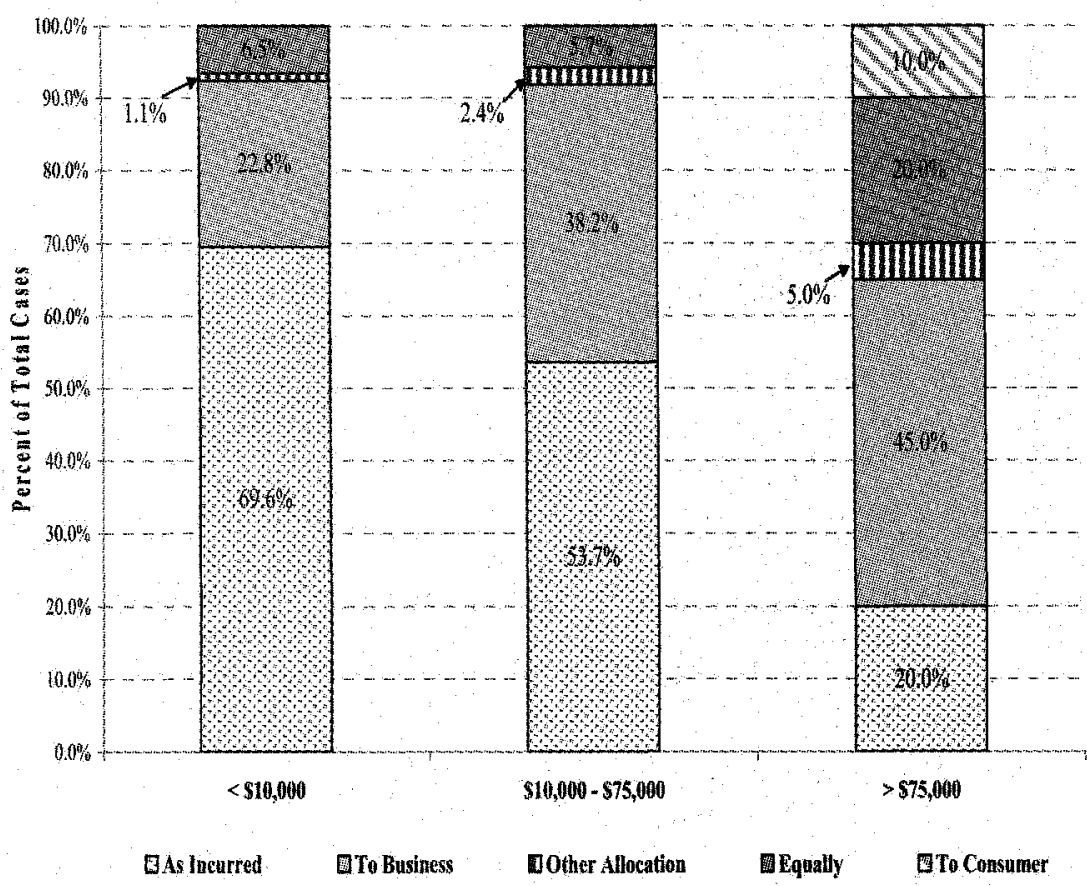

\section{Fees as Percent of Amount Claimed}

Finally, we calculated the total arbitration fees-AAA administrative fees and arbitrator's fees assessed to the consumer-as a percentage of the amount claimed. In the majority of the 235 cases in the case file sample with consumer claimants, total arbitration fees were $1 \%$ or less of the amount claimed, as shown in Figure 11. 


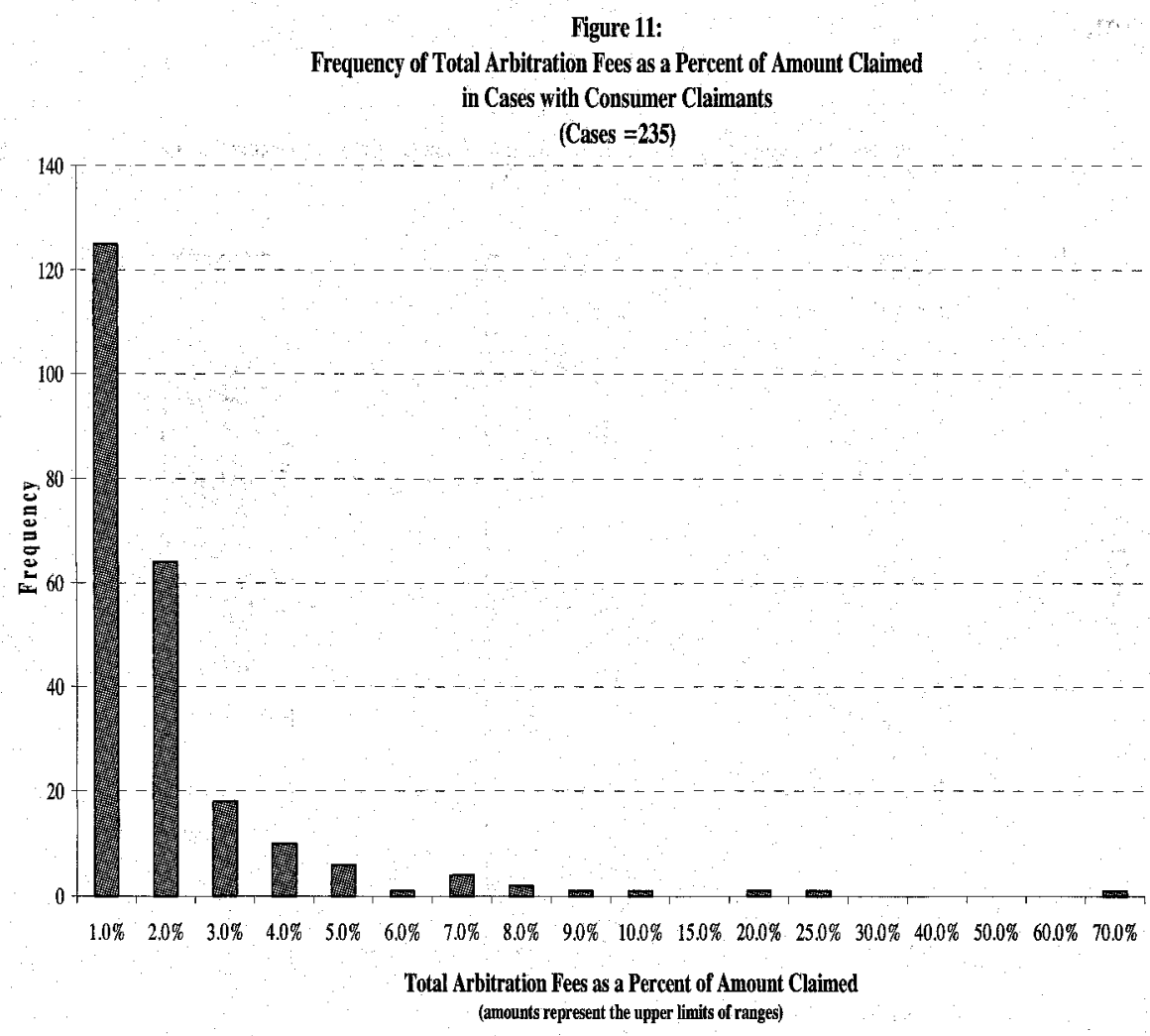

The range has a long tail, due largely to a single outlier. Total arbitration fees (i.e., both administrative and arbitrator's fees) ranged from $0.0 \%$ of the amount claimed to $65.1 \%$ of the amount claimed. The outlier was a case in which the amount sought was less than $\$ 200$. In no other case did the total arbitration costs exceed $25.0 \%$ of the amount claimed. The mean for the entire case file sample of total arbitration fees as a percent of amount claimed by consumers was $0.8 \%$. On average, for claims of $\$ 10,000$ or less, the ratio of total fees to amount claimed for consumer claimants was $1.6 \% ;{ }^{169}$ for claims between $\$ 10,000$ and $\$ 75,000$ the average ratio was $0.6 \%$; and for claims greater than $\$ 75,000$ the average ratio was $1.0 \%$.

Overall, the fees paid by consumer claimants typically constituted less than two percent of the amount claimed.

${ }^{169}$ Note that this result is due to the same outlier mentioned above. 


\section{Speed of AAA Consumer Arbitrations}

Arbitration is generally considered a relatively quick form of dispute resolution. Our results do not appear to contradict that impression, and are consistent with prior empirical studies on the issue. ${ }^{170}$ On average, for the 301 cases in the case file sample, the time from filing to final award was 207 days (6.9 months). ${ }^{171}$ The median time from filing to final award was 168 days (5.6 months), with a range of 64 to 992 days (2.1 months to 2.8 years). Cases with business claimants were about ten days shorter on average than cases with consumer claimants (198 days, or 6.6 months, instead of 209 days, or 7.0 months). The median duration for cases brought by business claimants likewise was about ten days shorter than for cases brought by consumer claimants (160 days, or 5.3 months, instead of 169 days, or 5.6 months). However, the range was greater for cases brought by business claimants (68 to 992 days, or 2.3 months to 2.8 years, as compared to 64 to 763 days, or 2.1 months to 2.1 years, for cases brought by consumer claimants). The upper tails of the ranges for business and consumer claimants were driven by a few outliers. Four cases involving consumer claimants lasted more than a year and a half; and three cases involving business claimants lasted more than a year and a half. Not surprisingly, cases with higher amounts claimed tended to take longer to resolve, as shown in Figure 12.

170 See supra Part II.B.

171 We were not able to find the filing date for one of the cases so we used the assignment date as a reasonable proxy. See Part IV.B for a discussion on the consistency tests of the AAA dataset. 


\section{AN EMPIRICAL STUDY OF AAA CONSUMER ARBITRATIONS}

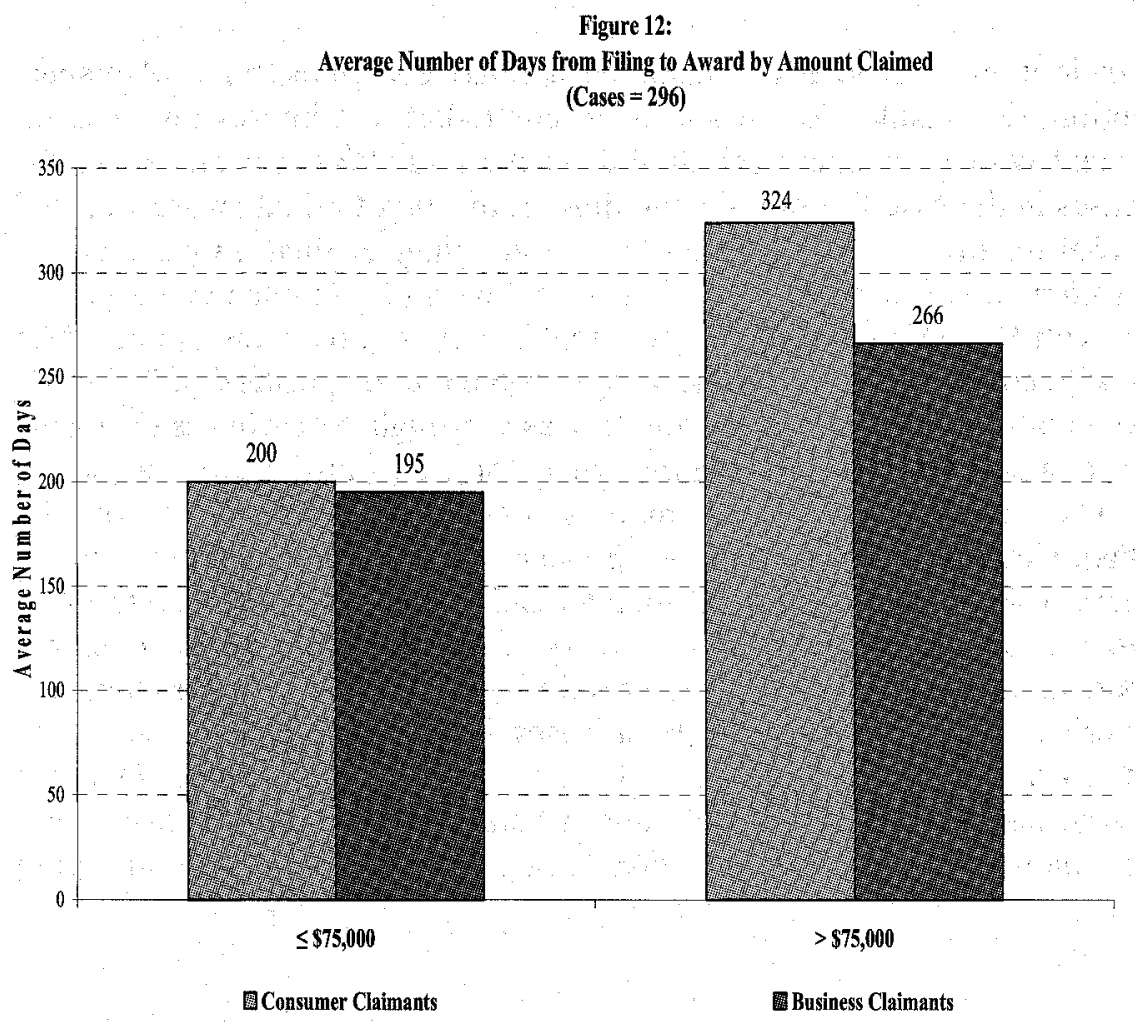

The time from filing to award changes substantially depending on the type of hearing involved in the case. In the majority of cases in the case file sample (187 of 301 , or $62.1 \%$ ), the arbitrator held either an in-person or telephone hearing. The remaining cases were resolved on the basis of documents only. ${ }^{172}$ Cases brought by consumer claimants whose claims were resolved on the basis of documents only were awarded in 139 days (4.6 months) on average, or a median of 125 days ( 4.2 months). Cases brought by consumer claimants and resolved by an in-person hearing were awarded in 235 days ( 7.8 months) on average for claims of $\$ 75,000$ or less and 336 days (11.2 months) on average for claims greater than $\$ 75,000 .{ }^{173}$ The comparable

172 In two cases, the arbitrator issued the final award pursuant to a motion for summary disposition; we did not include those two cases in the results for cases resolved on the basis of documents.

173 Clearly, it is not the time of the hearing itself that results in the greater time to an 
median times to award were 188 days (6.3. months) for claims of $\$ 75,000$ or less and 291 days $(9.7$ months) for claims greater than $\$ 75,000$. For consumer claims of $\$ 75,000$ or less, the difference in time from filing to award between cases resolved by documents only and cases resolved by inperson hearings is statistically significant. ${ }^{174}$ Figure 13 below shows the relative differences in average time from filing to award for consumer claimants by claim size.

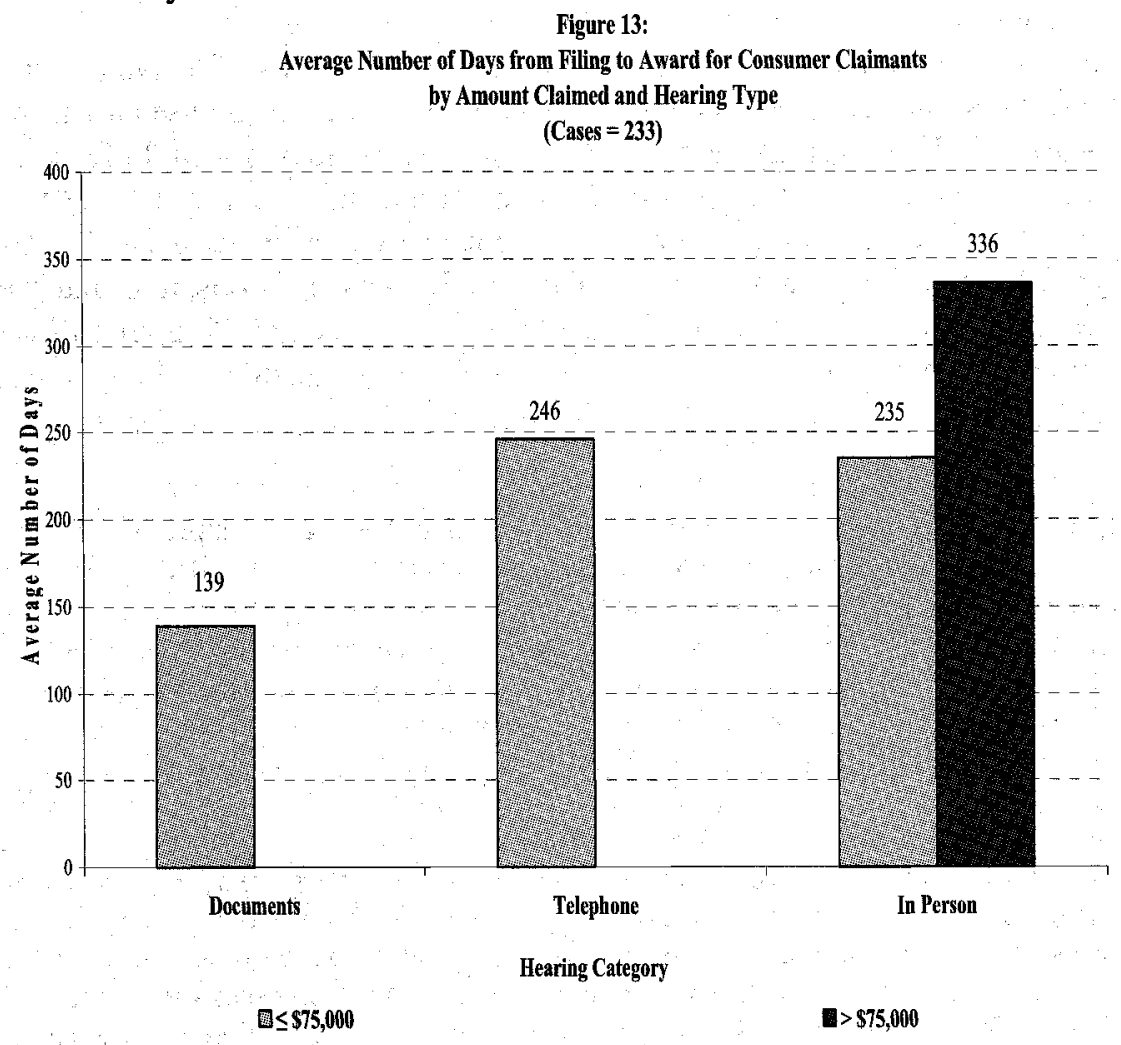

award. On average, in-person and telephone hearings lasted 1.23 days for cases with claims of $\$ 75,000$ or less, 1.91 days for cases with claims of more than $\$ 75,000$, and 1 day for nonmonetary claims. Instead, presumably, the greater complexity of the cases and the difficulties of scheduling in-person or telephone hearings account for the added time.

174 We used a two-group t-test for averages in number of days from filing to final award for cases resolved by documents only and for cases resolved by an in-person hearing. All cases were brought by consumer claimants seeking less than or equal to $\$ 75,000$. The t-statistic was 7.1718 (DF $=200.151$ and $p=0.0000$ and accounting for unequal variances), which indicates that we may reject the null hypothesis that the averages between the two groups were the same. 


\section{AN EMPIRICAL STUDY OF AAA CONSUMER ARBITRATIONS}

The milestone dates in the AAA consumer dataset were generally reliable, which permits us to use that dataset as a check on our findings from the case file sample. ${ }^{175}$ On average, the cases in the AAA dataset that were closed by an award from 2005 through 2007 (1114 cases) took 219 days (7.3 months) from filing to award, with a median case length of 176 days (5.9 months). Individual cases ranged in length from 55 days to 1203 days (or 1.8 months to 3.3 years). Overall, the results from the AAA consumer dataset are broadly consistent with the results from the case file sample. ${ }^{176}$

There is some potential for selection bias in both the case file sample and the AAA consumer dataset. The case file sample is limited to cases awarded from April 2007 through December 2007, and hence does not include cases that were filed during that period but awarded after December 2007. Similarly, the AAA consumer dataset does not include cases filed from 2005 through 2007 but resolved after December 2007. Thus, it is possible that, on average, our results somewhat understate the time to award. The amount of any understatement is not likely to change our results substantially, however. ${ }^{177}$

175 For the AAA consumer dataset, we use the assignment date as a proxy for filing date because the filing date was not captured. As discussed in Part IV.B, however, assignment date is a reasonable proxy for filing date.

176 The AAA consumer dataset did not track consistently whether the case was decided only by a review of documents or otherwise, so we could not use that dataset to check the results on type of hearing from the case file sample.

${ }^{177}$ By using cases filed or awarded in 2005 in the AAA consumer dataset as a reasonable proxy for the mix of cases filed or awarded in other years, we can examine the extent of any likely selection bias. Based on a review of case characteristics, we find no reason to believe that cases filed or awarded in 2005 would be systematically shorter or longer than cases filed or awarded in 2007. We also know of no exogenous event that might cause a difference in the types of cases filed in either year. We relied on the AAA consumer dataset and supplementary information from the AAA on cases still pending as of May 16, 2008, and February 18, 2009, to construct the set of cases filed or awarded in 2005. Specifically, we looked at: (1) all cases filed in 2005 and awarded by December 2007; (2) all cases awarded in 2005; and (3) any cases filed in 2005, and listed as still pending as of May 16, 2008 and February 18, 2009. (There might be some cases filed in 2005 but closed between January 1, 2008 and May 15, 2008, that we may not have captured in this analysis. But the number of such cases is likely to be very small, if any exist at all.) For the resulting 520 awarded cases, the average length of time from filing to award was 252 days (8.4 months), and the median length of time from filing to award was 206 days (6.9 months). Individual cases ranged in length from 65 to 1,151 days (2.2 months to 3.2 years). Additionally, according to the AAA, there were 57 cases filed in 2005 that were pending as of May 16,2008. These same 57 cases were still pending as of February 18, 2009. Of those cases, 53 are held in abeyance due to party agreement or 
As such, the average time from filing to award for AAA consumer arbitration cases is approximately seven to eight-and-a-half months. By comparison, the median time from filing to award for AAA consumer arbitration cases is approximately five-and-a-half to seven months.

\section{Outcomes of AAA Consumer Arbitrations}

In this section, we present the results of our analysis on outcomes in AAA consumer arbitrations. First, we describe limitations of the data as to outcomes. Second, we present general data on outcomes-win rates for consumer claimants and business claimants; amounts of compensatory damages, interest, punitive damages, and attorneys' fees awarded; and the amount of compensatory damages awarded as a percentage of the amount claimed. Third, we examine the relationship between outcome and whether the consumer was represented by counsel. Finally, we look at what our data suggest about the existence of a repeat-player effect and whether any such effect results from bias in favor of repeat businesses or from case screening by repeat businesses.

\section{Limitations of the Data}

We used data from the 301 cases in the case file sample to analyze outcomes because the AAA consumer dataset does not permit reliable tracking of party wins and award amounts. The case file sample has several limitations. First, as discussed above, claimants-particularly consumer claimants-do not always specify an exact amount demanded, sometimes seeking less than or more than a particular amount or a bounded range of amounts. ${ }^{178}$ Our approach for dealing with this issue is described above. ${ }^{179}$ Because only twenty-two cases with consumer claimants are affected, alternative approaches do not drastically change the results below.

Second, claimants sometimes include interest, punitive damages, attorneys' fees, or other damages in the amount claimed in the demand for arbitration, instead of only including the amount of compensatory damages

court order. Should any of these cases be awarded, the time to award in the case will be greater than 1,000 days. However, in the AAA consumer dataset, only four cases were pending for more than 1,000 days prior to an award; thus few, if any, of these 57 cases will likely be awarded. These cases are approximately 5\% of the total cases filed in 2005 . As such, they will not likely change the average of 252 days by a substantial amount.

178 See supra Part V.A.2.

${ }^{179} \mathrm{Id}$. 


\section{AN EMPIRICAL STUDY OF AAA CONSUMER ARBITRATIONS}

sought. ${ }^{180}$ In order to mitigate this problem, when collecting the data we segregated those other damage amounts from the amount of compensatory damages when possible. However, there may be some claim amounts that include interest or other damages or were amended without evidence in the file. Unless otherwise noted, in the calculations below we report percent recoveries using claims and awards of compensatory damages. Because claimants often did not claim specific amounts for other kinds of damages, calculating those percent recoveries was not possible.

Similar issues arise on the award side as well, although not as frequently. In general, arbitrators specified in the award the types of damages being awarded, although the award was not clear as to the breakdown of the amount awarded in a few cases. Again, this could overstate the amount of compensatory damages awarded.

Third, we consider any time the arbitrator found for the claimant and awarded damages of some kind to be a win for the claimant and a loss for the respondent, regardless of the amount awarded. We do not, however, treat the reallocation of arbitration costs alone as making the case a win for the claimant. We use this definition of a win for both initial claims and counterclaims. We recognize, as discussed above, that this definition may overstate the extent to which the claimant truly prevails on its claim. ${ }^{181} \mathrm{We}$ deal with that possibility by presenting data on the amount awarded as well as on win rates.

\section{General Outcomes}

Because of the differing nature of the respective claims, ${ }^{182}$ we present win rates for consumer claimants and business claimants separately. ${ }^{183}$ For cases with consumer claimants, the consumer won some relief in $53.3 \%$ (128 of 240) of the cases, as shown in Table 2. By comparison, for cases with

180 On some of the demand for arbitration forms used by the AAA, claimants can check a box to indicate whether they are seeking recovery of attorneys' fees, punitive damages, interest, arbitration costs, or other damages. See AAA, Form Demand for Arbitration, http://www.adr.org/si.asp?id $=3807$ (last visited Dec. 31, 2008). Because it is not clear that only compensatory damages be included in the line item for "Dollar amount of claim" on the form, it is possible that some claimants included these other items of damages in the amount claimed.

181 See supra Part II.C.

182 See supra Part V.A.1.

183 Note that we do not consider settlements in our win rates since we do not have enough data to determine whether their inclusion would be appropriate in this context. 
business claimants, the business won some relief in $83.6 \%$ (51 of 61 ) of the cases. ${ }^{184}$ The higher win rate for business claimants may be due to the fact that businesses tend to bring debt collection actions and other similar cases in which the likelihood of success for the business is high. ${ }^{185}$ Although we cannot reach any definitive conclusions about the success of consumer claimants because we have no baseline for comparison, ${ }^{186}$ at a minimum, we can conclude that the consumer claimants won some relief more often than they lost against businesses in AAA consumer arbitrations.

\section{Table 2: Win Rates by Case Type and Party}

\begin{tabular}{|r|cc|cc|}
\hline & $\begin{array}{c}\text { Cases with Consumer } \\
\text { Claimants Only }\end{array}$ & \multicolumn{2}{c|}{$\begin{array}{c}\text { Cases with Business } \\
\text { Claimants Only }\end{array}$} \\
\hline Party & Consumer & Business & Consumer & Business \\
\hline Wins & 128 & 112 & 10 & 51 \\
Total Cases & 240 & 240 & 61 & 61 \\
Win Rate & $\mathbf{5 3 . 3 \%}$ & $\mathbf{4 6 . 7 \%}$ & $\mathbf{1 6 . 4 \%}$ & $\mathbf{8 3 . 6 \%}$ \\
\hline
\end{tabular}

Consumer claimants who bring large claims tend to do better than consumers who bring smaller claims, although the number of consumers bringing large claims is small. As Table 3 shows, consumer claimants won some relief in $60.0 \%$ of cases ( 12 of 20 ) seeking more than $\$ 75,000$, and won some relief in $52.1 \%$ of cases (112 of 215 ) seeking $\$ 75,000$ or less. In both types of cases, the consumer claimant won some relief against the business more than half of the time.

184 If we include the fifty-seven counterclaims in the case file sample in the above analysis, consumer claimants won some relief in 53.4\% (134 of 251) of the cases and business claimants won some relief in $80.4 \%$ ( 86 of 107) of the cases.

185 See RUTLEDGE, GOOD DEAL, supra note 6 , at 10-11.

186 For a comparison of outcomes in debt collection arbitrations in the sample to outcomes in debt collection cases in court, see SEARLE CIVIL JUSTICE INST., supra note 11 , at $13-17,22-26$. 


\section{Table 3: Consumer Claimant Win Rates by Amount Claimed}

\begin{tabular}{|c|c|c|}
\hline & \multicolumn{2}{|c|}{$\begin{array}{l}\text { Cases with Consumer } \\
\text { Claimants Only }\end{array}$} \\
\hline Claim & $\leq \$ 75,000$ & $>\$ 75,000$ \\
\hline Consumer Wins & 112 & 12 \\
\hline Total Cases & 215 & 20 \\
\hline Consumer Win Rate & $52.1 \%$ & $60.0 \%$ \\
\hline
\end{tabular}

We also analyzed the amounts awarded to business and consumer claimants. Our results are summarized in Table 4.187 The mean amount awarded to business claimants in the case file sample was $\$ 20,648$ and the mean percent recovery was $93.0 \% .{ }^{188}$ The median amount awarded to business claimants was $\$ 11,110$ and the median percent recovery was $100.0 \%$. For consumer claimants, the mean amount awarded was $\$ 19,255$ and the mean percent recovery was $52.1 \%$, while the median amount awarded was $\$ 5000$ and the median percent recovery was $41.7 \%$.

187 Consumer claimants prevailed in an additional nine cases, but in those cases either the claim sought non-monetary relief or the dollar amount awarded was not available in the case file. Accordingly, we excluded those cases from our analysis. Since our definition of a win includes the claimant recovering any part of the claim, we did include two cases with consumer claimants who were awarded attorneys' fees but no compensatory damages.

188 In this section, all average percent recoveries were calculated as the average from a distribution of each claimant's percent recovery. 
Table 4: Compensatory Damages Recovered by Consumer Claimants and Business Claimants

\begin{tabular}{|c|c|c|c|c|c|c|}
\hline & \multicolumn{3}{|c|}{ 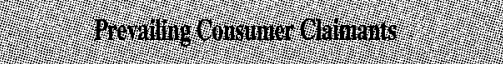 } & \multicolumn{3}{|c|}{ 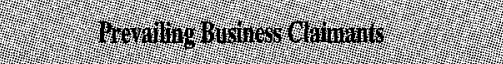 } \\
\hline & 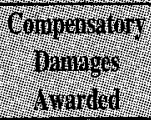 & 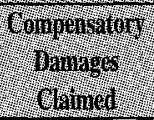 & 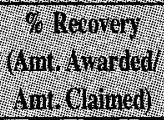 & 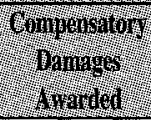 & 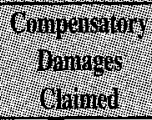 & 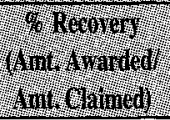 \\
\hline Maximum & $\$ 419,259$ & $\$ 500,000$ & $100.0 \%$ & $\$ 156,048$ & $\$ 156,048$ & $100.0 \%$ \\
\hline Minimum & $\$ 0$ & $\$ 178$ & $0.0 \%$ & $\$ 873$ & $\$ 1,215$ & $16.3 \%$ \\
\hline Average & $\$ 19,255$ & $\$ 40,955$ & $\mathbf{5 2 . 1 \%}$ & $\$ 20,648$ & $\$ 21,420$ & $93.0 \%$ \\
\hline Median & $\$ 5,000$ & $\$ 16,530$ & $41.7 \%$ & $\$ 11,110$ & $\$ 12,827$ & $100.0 \%$ \\
\hline Std. Dev. & $\$ 50,592$ & $\$ 67,056$ & $38.9 \%$ & $\$ 26,732$ & $\$ 27,138$ & $16.0 \%$ \\
\hline Cases & 119 & 119 & 119 & 51 & 51 & 51 \\
\hline
\end{tabular}

We also examined the amounts awarded to consumers based on whether the consumer claimed more or less than $\$ 75,000$, as shown in Table 5. The mean amount awarded to consumers claiming $\$ 75,000$ or less in the case file sample was $\$ 8871$ and the mean percent recovery was $51.6 \%$. The median amount awarded to consumers claiming $\$ 75,000$ or less was $\$ 4800$ and the median percent recovery was $41.6 \%$. For consumers claiming more than $\$ 75,000$, the mean amount awarded was $\$ 111,847$ and the mean percent recovery was $56.2 \%$, while the median amount awarded was $\$ 78,062$ and the median percent recovery was $72.7 \%$. Thus, prevailing consumers who claimed amounts in excess of $\$ 75,000$ tended to receive awards in excess of $\$ 75,000$. The average percent recovery between the two groups is similar, however.

Table 5: Compensatory Damages Recovered by Consumer Claimants by Amount Claimed

\begin{tabular}{|c|c|c|c|c|c|c|}
\hline & \multicolumn{3}{|c|}{ 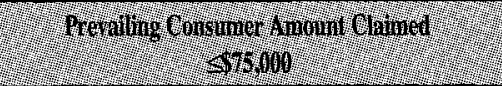 } & \multicolumn{3}{|c|}{ 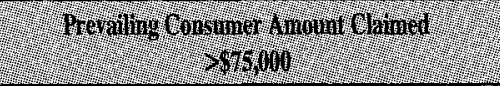 } \\
\hline & 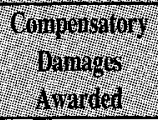 & $\begin{array}{l}\text { Compensior } \\
\text { Inounges }\end{array}$ & 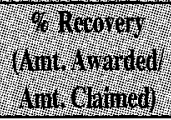 & 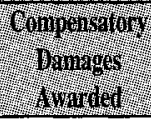 & 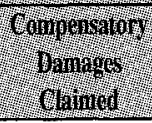 & 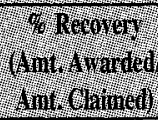 \\
\hline Maximum & $\$ 60,000$ & $\$ 75,000$ & $100.0 \%$ & $\$ 419,259$ & $\$ 500,000$ & $100.0 \%$ \\
\hline Minimum & $\$ 0$ & $\$ 178$ & $0.0 \%$ & $\$ 784$ & $\$ 80,000$. & $0.8 \%$ \\
\hline Average & $\$ 8,871$ & $\$ 23,816$ & $51.6 \%$ & $\$ 111,847$ & $\$ 193,785$ & $562 \%$ \\
\hline Median & $\$ 4,800$ & $\$ 12,378$ & $41.6 \%$ & $\$ 78,062$ & $\$ 150,000$ & $72.7 \%$ \\
\hline Std Dev. & $\$ 12,108$ & $\$ 23,069$ & $38.7 \%$ & $\$ 125,071$ & $\$ 121,527$ & $42.2 \%$ \\
\hline Cases & 107 & 107 & 107 & 12 & 12 & 12 \\
\hline
\end{tabular}




\section{AN EMPIRICAL STUDY OF AAA CONSUMER ARBITRATIONS}

Because we have no baseline for comparison, we cannot evaluate whether these recoveries are favorable or unfavorable for consumers. ${ }^{189} \mathrm{We}$ can say that the differing outcomes between business claimants and consumer claimants do not necessarily show that the process is unfair to consumers. Instead, the differing outcomes are likely due to the types of cases brought by business claimants and consumer claimants rather than any form of systematic bias. Business claimants usually bring claims for specific monetary amounts representing debts for goods provided or services rendered. Many of the cases are resolved ex parte, with the consumer failing to appear. ${ }^{190}$ By comparison, cases with consumer claimants are much less likely to involve liquidated amounts and more likely to be contested by businesses.

Figure 14 further illustrates the variation in awards of compensatory damages to business claimants and consumer claimants. In forty-one of the fifty-one cases in which a business claimant prevailed, the business recovered between $90.0 \%$ and $100.0 \%$ of the amount claimed. In contrast, the distribution of outcomes for prevailing consumer claimants is bimodal. In the 119 cases in which consumer claimants received monetary awards, the consumer recovered $20.0 \%$ or less of the amount claimed in 36 cases and between $90.0 \%$ and $100.0 \%$ of the amount claimed in thirty-seven cases. This bimodal distribution is consistent with studies of AAA commercial arbitration awards ${ }^{191}$ and international arbitration awards. ${ }^{192}$ It also suggests that arbitrators do not commonly make compromise awards in AAA consumer arbitrations. ${ }^{193}$

${ }^{189}$ See Part II.C.

190 Twenty-two of the sixty-one cases (36.1\%) brought by business claimants were resolved on an ex parte basis. The business won some relief in $100.0 \%$ of those twentytwo cases, and on average recovered $94.4 \%$ of the amount claimed.

191 American Arbitration Association, Splitting the Baby: A New AAA Study (Mar. 9, 2007), available at www.adr.org/sp.asp?id=32004.

192 Stephanie E. Keer \& Richard W. Naimark, Arbitrators Do Not "Split the Baby"-Empirical Evidence from International Business Arbitrations, 18 J. INT'L ARB. $573,575(2001)$.

193 See Hon. Richard A. Posner, Judicial Behavior and Performance: An Economic Approach, 32 FLA. ST. U. L. REV. 1259, 1260-61 (2005); Alan Scott Rau, Integrity in Private Judging, 38 S. TEX. L. REV. 485, 523 (1997). 


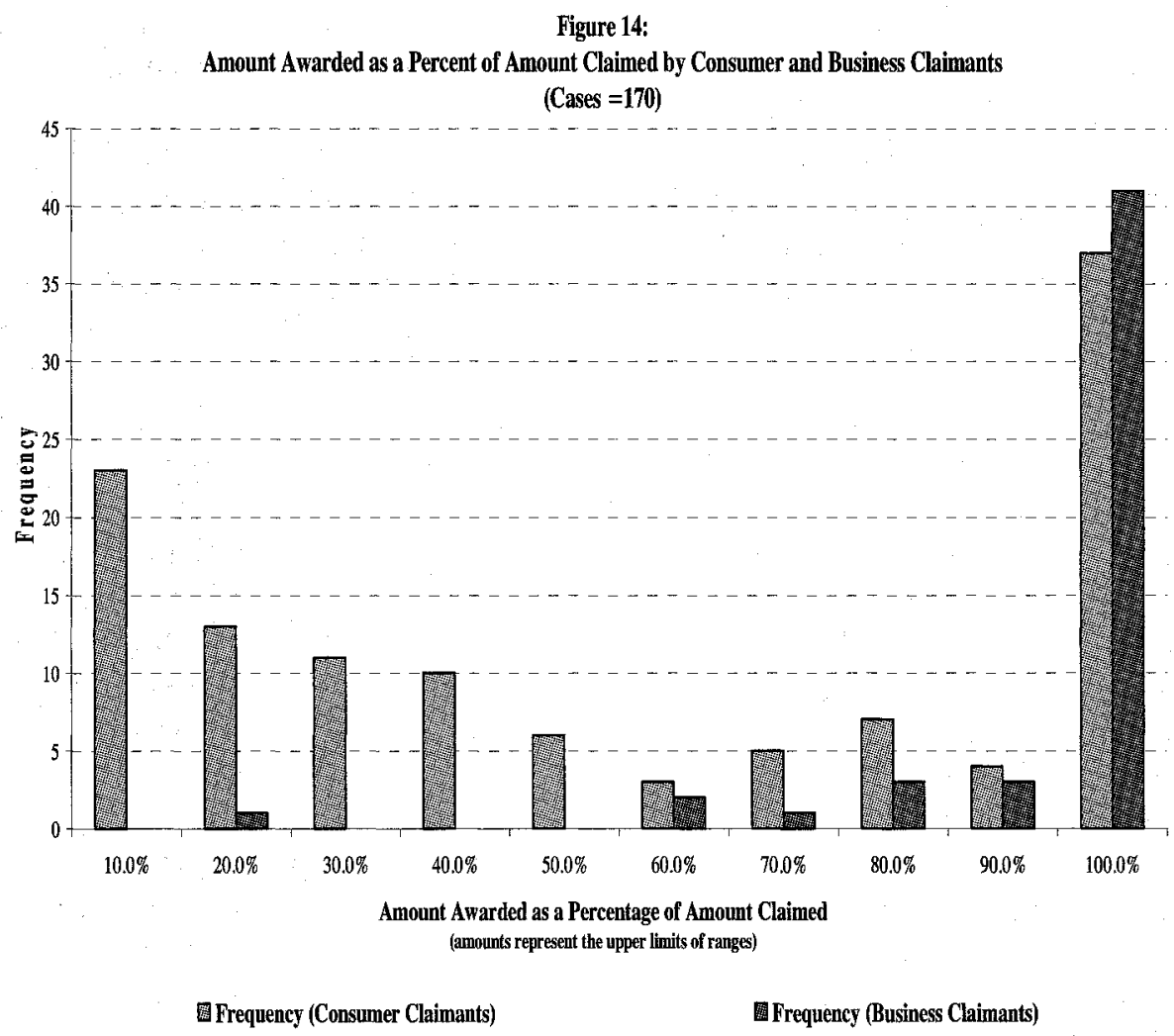

In addition to compensatory damages, prevailing claimants also were awarded other types of damages, including attorneys' fees, punitive damages, and interest.

In the case file sample, consumer claimants made a claim for attorneys' fees in sixty-five of the 128 cases (or 50.8\%) in which they prevailed. In forty-one of those sixty-five cases (or 63.1\%), the arbitrator awarded attorneys' fees to the consumer. ${ }^{194}$ In those cases in which the award of attorneys' fees specified a dollar amount (thirty-five cases), the average attorneys' fee award was $\$ 14,574$ and the median award was $\$ 9000$. Of

194 Because claimants sometimes amended their claims without formal indication in the AAA file, there are occasions where the claimant was awarded damages they had not originally requested. Since we understand from the AAA that the arbitrators are not to award damages beyond those claimed, we assume that claims for those damages were made. 
course, in forty-four of the sixty-three cases (or 69.8\%) in which prevailing consumer claimants did not seek attorneys' fees, they were proceeding pro se and did not have to pay for an attorney. ${ }^{195}$

Of the fifty-one cases in which the business claimant prevailed, the business made a claim for attorneys' fees in forty-one cases and was awarded those fees in sixteen cases (or 39.0\%). The mean attorneys' fee award was $\$ 2302$ and the median fee award was $\$ 1534$. The data in the files were not sufficient to determine the basis on which business claimants recovered attorneys' fees from consumers.

Awards of punitive damages were less common. Prevailing consumer claimants were awarded punitive damages in twelve of the forty-six (26.1\%) cases in which they were sought. The mean punitive damages award was $\$ 39,557$, while the median punitive award was $\$ 2100$. The higher mean is due to one case in which the consumer claimant received a punitive damages award of $\$ 427,500$. In contrast, prevailing business claimants almost never sought punitive damages. Of the fifty-one cases in which business claimants prevailed, the business sought punitive damages in three, and was awarded punitive damages in two. The average amount of punitive damages awarded in those two cases was $\$ 10,778$.

Arbitrators also awarded interest to prevailing parties that requested it in their claims. Prevailing consumer claimants were awarded interest in nineteen of the thirty-six cases (52.8\%) in which it was sought. Prevailing business claimants were awarded interest in twenty-one of the twenty-seven cases (or 77.8\%) in which it was sought. Because interest is often awarded without a specific dollar amount in the written awards, it is difficult to determine the magnitude of the amounts awarded.

\section{Pro Se Consumers}

In almost half ( 150 of 301 , or $49.8 \%)$ of the cases in the case file sample, consumers arbitrated the case themselves - that is, without an attorney. As Table 6 shows, consumer claimants were far more likely to be represented by counsel than consumer respondents. This difference may be due to the

195 There are four cases in which consumer claimants proceeded pro se, yet asked for attorneys' fees. In two of those cases, the arbitrator did not award attorneys' fees and the claim may have been a misunderstanding on the part of the claimant in filling out the arbitration demand form. The other two pro se consumer claimants were awarded attorneys' fees. However, both of theses cases came to arbitration from state courts, so the attorneys' fees claims may have resulted from fees incurred in state court or some other involvement of an attorney in the process. 
different type of claim involved, ${ }^{196}$ or to the fact that consumer claimants, unlike consumer respondents, might be represented on a contingency fee basis.

Table 6: Consumer Representation by Case Type

\begin{tabular}{|r|c|c|}
\hline & Cases with & Cases with \\
Consumer & Business Claimants Only* \\
\hline Represented by Attorney & $(55.4 \%)$ & 18 \\
Consumer & 103 & $(29.5 \%)$ \\
Proceeded Pro se & $(42.9 \%)$ & 22 \\
Consumer Did Not Appear & 4 & $(36.1 \%)$ \\
(Ex Parte Case) & $(1.7 \%)$ & 22 \\
& & $(36.1 \%)$ \\
Total Cases & 240 & 61 \\
\hline
\end{tabular}

* Note that one consumer respondent was represented by an attorney but eventually did not appear. This case appears twice in the above table in the Business Claimants column - once in the first row and again in the third row.

Accordingly, the total number of cases in which consumers proceeded pro se (150) consists of the entries in the table above for consumers proceeding pro se and consumers who did not appear, less the one case in which a consumer was represented by an attomey but did not appear.

As a general matter, pro se consumers have a lower win rate than consumers represented by attorneys, both in cases in which the consumers are claimants and in cases in which businesses are claimants. As Table 7 shows, pro se consumer claimants won some relief in $44.9 \%$ of the cases they brought, while consumer claimants with counsel won some relief in $60.2 \%$ of the cases they brought. By comparison, pro se consumers won in $7.0 \%$ of the cases brought by businesses, while consumer respondents with counsel won in $38.9 \%$ of such cases.

196 For a more detailed discussion of ex parte cases, see supra Part V.A.4. 
AN EMPIRICAL STUDY OF AAA CONSUMER ARBITRATIONS

Table 7: Consumer Win Rates by Case Type and Consumer Representation

\begin{tabular}{|c|c|c|c|c|c|c|}
\hline & \multicolumn{3}{|c|}{ 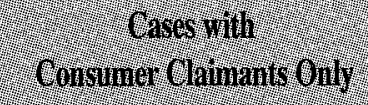 } & \multicolumn{3}{|c|}{ 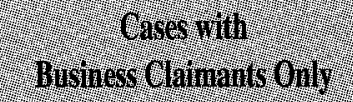 } \\
\hline 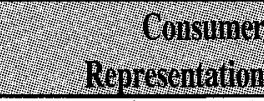 & MII & Allome & mises & $\operatorname{lin}$ & Allomey & 1910 \\
\hline Consumer Wins & 128 & 80 & 48 & 10 & 7 & 3 \\
\hline Total Cases & 240 & 133 & 107 & 61 & 18 & 43 \\
\hline Consumer Win Rate & $533 \%$ & $60.2 \%$ & $44.9 \%$ & $16.4 \%$ & $38.9 \%$ & $7.0 \%$ \\
\hline
\end{tabular}

The results are similar if we take into account the amount claimed. As Table 8 shows, consumer claimants fare better when represented by an attorney both for cases in which the claimant seeks $\$ 75,000$ or less, and for cases in which the claimant seeks more than $\$ 75,000$, although pro se claimants are much less common in the latter category.

Table 8: Consumer Claimant Win Rates by Amount Claimed and Representation

\begin{tabular}{|c|c|c|c|c|}
\hline & \multicolumn{2}{|c|}{ Gonsumer Amount claimed } & \multicolumn{2}{|c|}{ 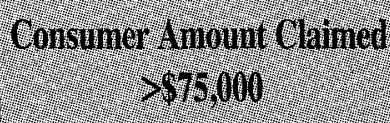 } \\
\hline Pepresitim & Atomey & ninse & Altomey & $120 \mathrm{se}$ \\
\hline Consumer Wins & & 45 & 11 & 1 \\
\hline Total Cases & 115 & 100 & 16 & 4 \\
\hline Consumer Win Rate & $58.3 \%$ & $45.0 \%$ & $68.8 \%$ & $25.0 \%$ \\
\hline
\end{tabular}

At least two explanations are possible for the higher success rate of consumers with attorneys. ${ }^{197}$ First, hiring an attorney may increase the

197 Prior empirical studies on employment arbitration report mixed results on the question. Compare Colvin, supra note 13, at 433 ("[T] percent where represented by counsel and only 13.7 percent where the employee was 
consumer's likelihood of success because of the specialized advocacy skills of an attorney. ${ }^{198}$ Second, in deciding whether to take on a client, attorneys accept only cases that are more likely to prevail, screening out less meritorious cases. From our data, we are unable to distinguish between these two explanations.

In addition to a higher win rate, consumer claimants who are represented by attorneys also tend to receive higher damages awards. As shown in Table 9,199 consumer claimants with attorneys received an average award of $\$ 27,233$ and a median award of $\$ 6702$, while pro se claimants received an average award of $\$ 5656$ and a median award of $\$ 3029.200$

Similar explanations are possible here as with win rates-either attorneys are able to obtain higher recoveries for their clients, or attorneys screen cases for those with higher potential recoveries. Our data again are unable to distinguish definitively between these two explanations, although they are suggestive. All consumer claimants who filed claims and were represented by attorneys sought an average of $\$ 57,529$ in compensatory damages, while pro se claimants sought an average of $\$ 31,774$, a difference that is statistically significant, albeit at the $10 \%$ level. ${ }^{201}$ Likewise, median claim amounts are higher for consumer claimants with attorneys $(\$ 32,000$ versus $\$ 8576$ for pro se claimants). While higher claim amounts may in part reflect value added by attorneys, it seems likely that a substantial part of the difference reflects the underlying value of the claim. As such, the data at

self-represented, a statistically significant difference . . . .") with Hill, Fair Forum, supra note 89, at 15 ("The win-loss ratio for both lower-income employees with representation and those who proceeded pro se was .50."); Hill, Due Process, supra note 89, at 819 (reporting similar results).

198 Because of the less formal nature of arbitration, this explanation seems somewhat weaker than it would as applied to a case in court, although clearly at least some of an attorney's skills are transferable from court to arbitration.

199 The outcomes results are only for those cases with known amounts of compensatory damages claimed and awarded.

${ }^{200}$ We used a two-group t-test for averages in compensatory damages awards to pro se consumer claimants and consumer claimants with counsel, excluding non-monetary claims and awards and accounting for unequal variances. The t-statistic was 2.9591 (DF $=78.6227$ and $\mathrm{p}=0.0041$ ), which indicates that we may reject the null hypothesis that the averages between the two groups were the same.

201 We used a two-group $t$-test for averages in claims made by represented and pro se consumer claimants, excluding non-monetary claims and accounting for equal variances. The $t$-statistic was $1.7093(\mathrm{DF}=233$ and $\mathrm{p}=0.0887)$, which indicates that we failed to reject the null hypothesis that the averages between the two groups were the same at higher than the $10 \%$ level. 


\section{AN EMPIRICAL STUDY OF AAA CONSUMER ARBITRATIONS}

least suggest that consumer claimants are more likely to be represented by counsel in cases with higher stakes. ${ }^{202}$

Table 9: Compensatory Damages Recovered by Consumer Claimants by Consumer Representation

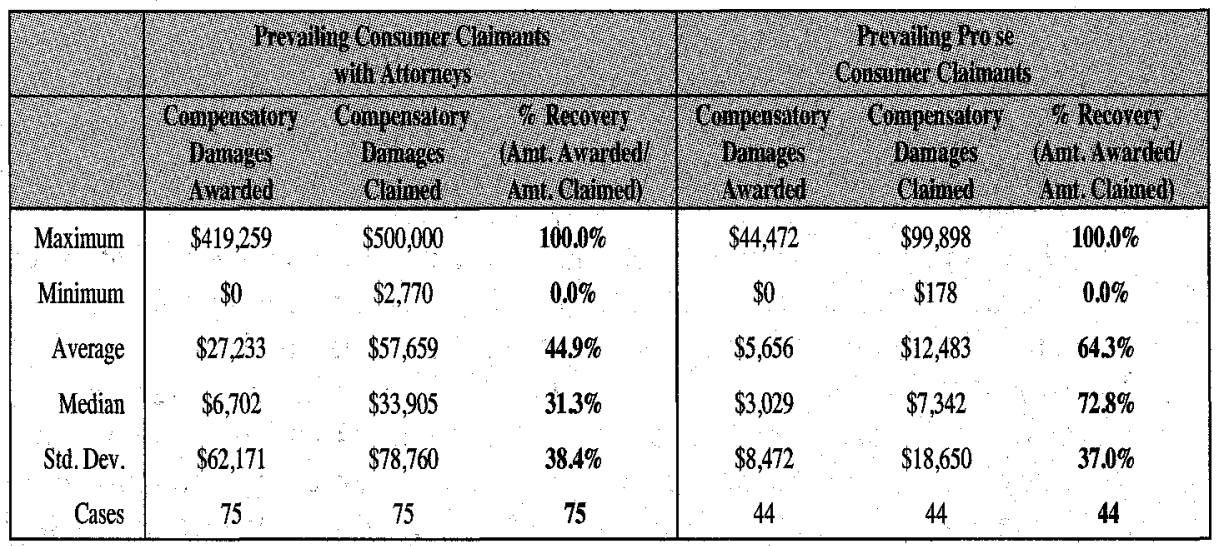

Two additional results are worth noting. First, pro se consumer claimants recovered a higher percentage of the amount claimed than consumers who were represented by attorneys. Prevailing pro se consumer claimants averaged a $64.3 \%$ recovery of the amount claimed, while prevailing consumer claimants with attorneys averaged a $44.9 \%$ recovery of the amount claimed. We have no clear explanation for this finding. ${ }^{203}$

Second, consistent with findings reported in the previous section, ${ }^{204}$ of the eighty cases in which prevailing consumer claimants were represented by attorneys, the claimant was awarded attorneys' fees in thirty-nine of the sixty-one cases in which they were sought (a success rate of $63.9 \%$ ). The frequency with which attorneys' fees are awarded in arbitration provides at least some incentive for attorneys to agree to represent consumers in arbitration.

202 Attorneys will be more likely to accept cases with higher stakes, while cases with lower stakes may encourage consumers to minimize their costs and forego legal representation.

203 One possibility is that attorneys are more aggressive in formulating damages claims than pro se claimants. A second possibility is that attorneys are less precise in their demands, specifying ranges rather than precise amounts of damages.

204 See supra Part V.D.2. 


\section{Repeat-Player Effect}

As discussed above, previous research on employment arbitration has found a "repeat-player effect," in which businesses that arbitrate on a regular basis tend to have a higher win rate than businesses that arbitrate less often. ${ }^{205}$ Several possible explanations for the repeat-player effect have been offered. The first is that the repeat-player effect is due to bias on the part of arbitrators and arbitration service providers, seeking to curry favor with businesses that are more likely to provide future business. The second is that businesses are able to structure the arbitration process in a favorable manner through their control of dispute system design. The third is that the repeatplayer effect is due to case selection by repeat businesses, who are more sophisticated in their case screening than non-repeat businesses. We first look at whether there is a repeat-player effect in the AAA's consumer cases. Finding some evidence of such an effect, we then test for whether the effect is likely due to bias (of arbitrators or otherwise) or case selection.

To test for the presence of a repeat-player effect, we used two different definitions of repeat business. First, we defined a business to be a repeat business when it appeared more than once in the AAA consumer dataset. ${ }^{206}$ We refer to a business that meets this definition of a repeat business as a "repeat(1) business." Second, we used information from the AAA business list (which it maintains to help in administering the Consumer Due Process Protoco ${ }^{207}$ ) to identify a category of repeat businesses. On the AAA business list, the AAA identifies a sub-category of "acceptable businesses" (businesses for which it will administer consumer arbitrations). The businesses in this sub-category are typically large entities for which there had been some prior confusion over the appropriate contact person when a consumer brought a claim against the business. For those businesses, the AAA business list typically identifies an appropriate contact person to receive the demand for arbitration. The fact that those businesses have had additional dealings with the AAA in administering their consumer arbitrations may make it appropriate to treat them as repeat businesses. We

205 See supra Part II.C.

206 This definition is similar to that used in other studies in that it focuses on the number of times the business appears in cases in the case file sample. E.g., Colvin, supra note 13, at 430; Hill, Fair Forum, supra note 89, at 15. It differs from other studies in that we are able to use a broader sample of cases in determining the number of times the business appears.

207 See CONSUmer arbitration TASK Force, SEARle Civil Just. Inst., CONSUMER ARBITRATION BEFORE THE AMERICAN ARBITRATION ASSOCIATION 42 (2009). 
refer to businesses that meet this definition of repeat business as "repeat(2) businesses."

Using the first definition of repeat business (businesses who appear more than once in the AAA consumer dataset), we do not find statistically significant evidence of a repeat-player effect in the cases in the case file sample. As shown in Table 10, consumer claimants won some relief in $51.8 \%$ of cases against repeat(1) businesses and $55.3 \%$ of cases against nonrepeat businesses, a difference that is not statistically significant. ${ }^{208}$ In cases in which the business is the claimant, consumers won some relief in $13.3 \%$ of cases against repeat(1) businesses and $25.0 \%$ of cases against non-repeat businesses. But in this latter case the sample size is too small to reliably test for a statistically significant difference. Again, using this definition of repeat business we do not find a statistically significant repeat-player effect. Moreover, consumer claimants still recover some amount against both repeat(1) and non-repeat businesses over half the time in the case file sample.

Table 10: Consumer Win Rates by Case Type and Presence of a Repeat(1) Business

\begin{tabular}{|c|c|c|c|c|c|c|}
\hline \multirow[b]{2}{*}{ Business thpe } & \multicolumn{3}{|c|}{ Gonsimer Caimants Only } & \multicolumn{3}{|c|}{$\begin{array}{l}\text { Cases with } \\
\text { Business Claimants Only }\end{array}$} \\
\hline & $A 1$ & repeain) & $\begin{array}{l}\text { Nont } \\
\text { Repeat } \\
\text { Repti }\end{array}$ & AII & Repeat 1$)$ & $\begin{array}{l}\text { Non- } \\
\text { Repeat } \\
\end{array}$ \\
\hline Consumer Wins & 128 & 71 & 57 & 10 & 6 & 4 \\
\hline Total Cases & 240 & 137 & 103 & 61 & 45 & 16 \\
\hline Consumer Win Rate & $533 \%$ & $51.8 \%$ & $\mathbf{5 5 . 3} \%$ & $16.4 \%$ & $13.3 \%$ & $25.0 \%$ \\
\hline
\end{tabular}

The results are similar when we categorize consumer claimants by amount claimed. The difference in Table 11 is that consumers tend to do better against repeat(1) businesses when claiming more than $\$ 75,000$, although, again, the sample size is too small for reliable statistical analysis.

208 The Pearson's Chi-squared statistic is $0.2919(\mathrm{DF}=1$ and $\mathrm{p}=0.589)$, which fails to allow us to reject the null hypothesis that consumer wins are not associated with whether the respondent is a repeat( 1 ) business. 
Table 11: Consumer Claimant Win Rates by Amount Claimed and Presence of a Repeat(1) Business

\begin{tabular}{|c|c|c|c|c|}
\hline 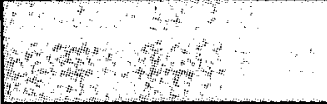 & Consumer & $\begin{array}{l}\text { ant Claimed } \\
\text { to }\end{array}$ & Consumer & int Claimed \\
\hline Hot Business Type & Repeat(1) & Non-Repeat & Repeat(1) & Non-Repeat \\
\hline Consumer Wins & 60 & 52 & 7 & 5 \\
\hline Total Cases & 121 & 94 & 11 & 9 \\
\hline Consumer Win Rate & $49.6 \%$ & $55.3 \%$ & $63.6 \%$ & $55.6 \%$ \\
\hline
\end{tabular}

As shown in Table 12, consumers who prevail against a repeat(1) business are awarded a higher percentage of the mean (and median) amount of compensatory damages claimed than consumers who prevail against nonrepeat businesses. Prevailing consumer claimants are awarded on average $60.9 \%$ of compensatory damages claimed against repeat(1) businesses (and $75.6 \%$ of compensatory damages claimed at the median) and on average $41.4 \%$ of the amount claimed against non-repeat businesses (and 31.4\% of the amount claimed at the median), a statistically significant difference. ${ }^{209}$ Although we have no clear explanation for these results, at a minimum, they seem inconsistent with the existence of a repeat-player effect. ${ }^{210}$

209 We used a two-group t-test for averages in percent recoveries between consumer claimants arbitrating against repeat(1) businesses and non-repeat businesses, excluding non-monetary claims and awards and accounting for equal variances. The t-statistic was $2.7983(\mathrm{DF}=117$ and $\mathrm{p}=0.0060)$, which indicates that we may reject the null hypothesis that the averages between the two groups were the same.

210 Some other studies include zero dollar awards (i.e., claimant losses) in calculations of the percentage recovery, which makes comparisons to those studies difficult. See Colvin, supra note 13, at 429-31. We exclude zero dollar awards from Table 12 so that we can examine percentage recovery separately from win rate; including zero dollars awards would conflate the two measures. 


\section{AN EMPIRICAL STUDY OF AAA CONSUMER ARBITRATIONS}

Table 12: Compensatory Damages Recovered by Consumer Claimants by Presence of a Repeat(1) Business

\begin{tabular}{|c|c|c|c|c|c|c|}
\hline & \multicolumn{3}{|c|}{$\begin{array}{l}\text { Prevailing Consumer Claimants } \\
\text { Repeat (1) Business Present }\end{array}$} & \multicolumn{3}{|c|}{$\begin{array}{l}\text { Prevaling Consumer Chimants } \\
\text { Non-Repeat Business Preseni }\end{array}$} \\
\hline$F$ & $\begin{array}{l}\text { Compensatory } \\
\text { Damages } \\
\text { Axarded }\end{array}$ & $\begin{array}{l}\text { Compensatory } \\
\text { Damages } \\
\text { Chained }\end{array}$ & $\begin{array}{l}\text { \% Recoriery } \\
\text { (Amt. Avarded } \\
\text { Amt. Clatuad) }\end{array}$ & $\begin{array}{c}\text { Compensatory } \\
\text { Damages } \\
\text { Awarded } \\
\end{array}$ & $\begin{array}{l}\text { Compensatory } \\
\text { Damages } \\
\text { Claimed }\end{array}$ & $\begin{array}{l}\text { O Becorery } \\
\text { (Amt. Awarded } \\
\text { Ant, Clained) }\end{array}$ \\
\hline Maximum & $\$ 250,000$ & $\$ 300,000$ & $100.0 \%$ & $\$ 419,259$ & $\$ 500,000$ & $100.0 \%$ \\
\hline Minimum & $\$ 1$ & $\$ 178$ & $0.0 \%$ & $\$ 0$ & $\$ 538$ & $0.0 \%$ \\
\hline Average & $\$ 20,084$ & $\$ 39,467$ & $609 \%$ & $\$ 18,256$ & $\$ 42,746$ & $41.4 \%$ \\
\hline Median & $\$ 6,000$ & $\$ 12,000$ & $75.6 \%$ & $\$ 4,475$ & $\$ 22,742$ & $31 A \%$ \\
\hline Std. Dev. & $\$ 43,407$ & $\$ 59,386$ & $39 A \%$ & $\$ 58,494$ & $\$ 75,805$ & $358 \%$ \\
\hline Cases & 65 & 65 & 65 & 54 & 54 & 54 \\
\hline
\end{tabular}

Using the second definition of repeat business (based on a sub-category of businesses on the AAA business list), we find a greater repeat-player effect, at least as to win rates, albeit one that is weakly statistically significant. As Table 13 shows, consumer claimants won some relief in $43.4 \%$ of cases against repeat(2) businesses and $56.1 \%$ of cases against nonrepeat businesses, a difference that is statistically significant at the $10 \%$ level. ${ }^{211}$ In cases in which the business is the claimant, consumers won in none of the cases against repeat(2) businesses and $16.4 \%$ of cases against non-repeat businesses. But in this latter case the sample size is too small for reliable tests of statistical differences.

Table 13: Consumer Win Rates by Case Type and Presence of a Repeat(2) Business

\begin{tabular}{|c|c|c|c|c|c|c|}
\hline Hith & \multicolumn{3}{|c|}{$\begin{array}{l}\text { Cases with } / 7 / \\
\text { Consumer Claimants Only }\end{array}$} & \multicolumn{3}{|c|}{$\begin{array}{l}\text { Cases vith } \\
\text { Business Claimants Only }\end{array}$} \\
\hline Business Type & All. & $\operatorname{Repeat}(2)$ & $\begin{array}{l}\text { Non- } \\
\text { Repeat }\end{array}$ & All $/$ : & Repeat(2) & $\begin{array}{l}\text { Non- } \\
\text { Repeat }\end{array}$ \\
\hline Consumer Wins & 128 & 23 & 105 & 10 & 0 & 10 \\
\hline Total Cases & 240 & 53 & 187 & 61 & 7 & 54 \\
\hline Consumer Win Rate & $53.3 \%$ & $43.4 \%$ & $56.1 \%$ & $16.4 \%$ & $0.0 \%$ & $18.5 \%$ \\
\hline
\end{tabular}

211 The Pearson's Chi-squared statistic is 2.6987 (DF $=1$ and $\mathrm{p}=0.100$ ), which fails beyond the $10 \%$ level to allow us to reject the null hypothesis that consumer wins are not associated with whether the respondent is a repeat(2) business. 
The results are similar when we categorize consumer claimants by the amount claimed, as Table 14 indicates. The win rate for consumer claimants seeking $\$ 75,000$ or less is $39.1 \%$ against repeat(2) businesses and $55.6 \%$ against non-repeat businesses, a statistically significant difference at the $5 \%$ level. ${ }^{212}$ By comparison, consumers seeking more than $\$ 75,000$ won some relief more often against repeat(2) businesses than against non-repeat businesses, but the number of such cases is too small to reliably test the results statistically.

Table 14: Consumer Claimant Win Rates by Amount Claimed and Presence of a Repeat(2) Business

\begin{tabular}{|c|c|c|c|c|}
\hline 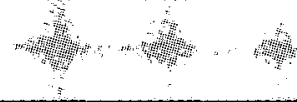 & \multicolumn{2}{|c|}{$\begin{array}{l}\text { Consumer Amount Claimed } \\
\qquad \$ 75,000\end{array}$} & \multicolumn{2}{|c|}{$\begin{array}{l}\text { Consumer Amount Claimed } \\
\qquad \$ \$ 75,000\end{array}$} \\
\hline Business Type & $\operatorname{Repeat}(2)$ & Non-Repeat & Repeat(2) & Non-Repeat \\
\hline Consu & 18 & 94 & 4 & 8 \\
\hline Total Cases & 46 & 169 & 5 & 15 \\
\hline Consumer Win Rate & $39.1 \%$ & $55.6 \%$ & $80.0 \%$ & $533 \%$ \\
\hline
\end{tabular}

Again, as Table 15 shows, if consumer claimants do prevail on their claim, they are awarded on average an almost identical percent of the amount claimed against repeat(2) businesses (52.4\%) as against non-repeat businesses $(52.0 \%){ }^{213}$ The results are reversed for the median, with prevailing consumer claimants being awarded at the median a lower percentage of the amount claimed against repeat(2) businesses (39.5\%) than against non-repeat businesses $(41.7 \%)$.

212 The Pearson's Chi-squared statistic is $3.9402(\mathrm{DF}=1$ and $\mathrm{p}=0.0470$ ), which fails beyond the $5 \%$ level to allow us to reject the null hypothesis that consumer wins for cases with claims of less than $\$ 75,000$ are not associated with whether the respondent is a repeat(2) business.

${ }^{213} \mathrm{We}$ used a two-group t-test for averages in percent recoveries between consumer claimants arbitrating against repeat(2) businesses and non-repeat businesses, excluding non-monetary claims and awards and accounting for equal variances. The $t$-statistic was 0.0485 (DF $=117$ and $p=0.9614$ ), which indicates that we failed to reject the null hypothesis that the averages between the two groups were the same. 


\section{AN EMPIRICAL STUDY OF AAA CONSUMER ARBITRATIONS}

Table 15: Compensatory Damages Recovered by Consumer Claimants by Presence of a Repeat(2) Business

\begin{tabular}{|c|c|c|c|c|c|c|}
\hline$=\quad \therefore$ & \multicolumn{3}{|c|}{$\begin{array}{l}\text { Prevailing Consumer Clatuants } \\
\text { Repeat(2) Business Present }\end{array}$} & \multicolumn{3}{|c|}{$\begin{array}{c}\text { Prevaillag Consumer Ctaimauts } \\
\text { Non-Repeat Business Present }\end{array}$} \\
\hline 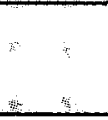 & $\begin{array}{l}\text { Compensatory } \\
\text { Damages } \\
\text { Awarded }\end{array}$ & $\begin{array}{c}\text { Compensatory } \\
\text { Damages } \\
\text { Claimed } \\
\end{array}$ & $\begin{array}{c}\text { \% Recorery } \\
\text { (Amt.Awarded } \\
\text { Amt.Clained) } \\
\end{array}$ & $\begin{array}{l}\text { Compensatory } \\
\text { Damages } \\
\text { Awrarded }\end{array}$ & $\begin{array}{l}\text { Compensatory } \\
\text { Damages } \\
\text { Claimed } \\
\end{array}$ & $\begin{array}{l}\text { \% Recorery } \\
\text { (Amt. Awarded/ } \\
\text { Amt. Claimed) }\end{array}$ \\
\hline Maximum & $\$ 250,000$ & $\$ 250,000$ & $100.0 \%$ & $\$ 419,259$ & $\$ 500,000$ & $100.0 \%$ \\
\hline Minimum & $\$ 15$ & $\$ 178$ & $03 \%$ & $\$ 0$ & $\$ 192$ & $0.0 \%$ \\
\hline Average & $\$ 26,693$ & $\$ 46,803$ & $52.4 \%$ & $\$ 17,568$ & $\$ 39,629$ & $52.0 \%$ \\
\hline Median & $\$ 4,500$ & $\$ 23,313$ & $39.5 \%$ & $\$ 5,000$ & $\$ 15,893$ & $41.7 \%$ \\
\hline Std. Dev. & $\$ 56,537$ & $\$ 62,958$ & $40.1 \%$ & $\$ 49,309$ & $\$ 68,193$ & $38.8 \%$ \\
\hline Cases & 22 & 22 & 22 & 97 & 97 & 97 \\
\hline
\end{tabular}

Overall, then, we find some evidence of a repeat-player effect when using our second definition of repeat business, and even then only as to win rates and not as to percentage recoveries. But as discussed above, ${ }^{214}$ the existence of a repeat-player effect does not necessarily show arbitrator (or other) bias in favor of repeat businesses. Instead, a repeat-player effect also may result from case selection by repeat businesses, who settle meritorious claims and arbitrate only weaker claims, while non-repeat businesses are more likely to arbitrate all claims, even meritorious ones.

Our evidence tends not to support the hypothesis that arbitrator (or other) bias is the likely explanation for any repeat-player effect in the case file sample. First, cases with repeat player combinations of any kind make up a small portion of the case file sample. Second, and perhaps more importantly, we find evidence that case screening by businesses may explain any repeatplayer effect in the case file sample. Specifically, we find that repeat businesses are more likely to settle or otherwise close cases before an award than non-repeat businesses.

First, a small percentage of cases in the case file sample involved any combination of repeat players, such as repeat pairs of arbitrators and businesses, arbitrators and attorneys for businesses, arbitrators and consumers, arbitrators and attorneys for consumers, as well as businesses and consumers. In the case file sample, 35 of 301 cases $(11.6 \%)$ involved repeat

214 See supra Part II.C. 
pairs of any kind (see Table 16). ${ }^{215}$ Of those thirty-five cases, seven involved business claimants and twenty-eight involved consumer claimants.

\section{Table 16: Cases with Repeat Combinations}

\begin{tabular}{|r|c|}
\hline Combination Type & Number of Cases \\
\hline Arbitrator and Business & 27 \\
Arbitrator and Business Attorney & 29 \\
Arbitrator and Consumer & 2 \\
Arbitrator and Consumer Attorney & 11 \\
Business and Consumer & 4 \\
\hline
\end{tabular}

In all of the cases with repeat combinations that were brought by business claimants, the business won some relief ( 7 of 7 , or $100.0 \%$ ), which may be due to the types of cases involved. However, in two of those cases the consumers asserted counterclaims and won some relief on those counterclaims both times.

In the twenty-eight cases with consumer claimants, consumers won some relief in twelve (or $42.9 \%$ of the cases), a slightly lower win rate than for the entire case file sample. 216 This lower win rate might be due to the fact that the majority of the consumers in the cases with repeat combinations were proceeding pro se (16 out of 28 cases, or $57.1 \%$ ), a higher rate than for the entire case file sample. ${ }^{217}$ Because pro se consumers tend to have a lower win rate than consumers with attorneys, ${ }^{218}$ it may be the lack of legal

215 Multiple repeat pairs were present in many of the cases. Hence, the numbers in Table 16 add to significantly more than the total thirty-five cases with repeat pairs.

216 Thirteen of the twenty-eight cases involved the same business respondent; consumers won some relief in roughly half of those cases (6 of 13 , or $46.2 \%$ ). Due to the small number of cases, we cannot reliably test this difference statistically.

217 Due to the small number of cases, we cannot reliably test this difference statistically.

218 See supra Part V.D.3. 
representation rather than the presence of a repeat pair that explains the lower win rate in these cases. ${ }^{219}$

Second, if the repeat-player effect were due to case screening rather than arbitrator bias, one might expect that repeat businesses would be more likely to settle or otherwise resolve cases before an award than non-repeat businesses. To test for this possibility, we used the AAA consumer dataset, limited to the same period (April-December 2007) as the case file sample. Table 17 summarizes case dispositions (either as awarded or non-awarded) for cases in which consumer claimants brought claims against repeat(2) businesses. ${ }^{220}$ Of consumer claims against repeat(2) businesses, 71.1\% (133 of 187) were resolved prior to an award, while 54.6\% (226 of 414) of consumer claims against non-repeat businesses were resolved prior to an award, a statistically significant difference. ${ }^{221}$ Thus, consistent with the hypothesis that the repeat-player effect is due to case screening, we find that repeat businesses are more likely to resolve cases prior to an award.

\section{Table 17: Disposition of Cases by Consumer Claimants Against Repeat(2) and Non-Repeat Businesses}

\begin{tabular}{|r|c|c|}
\hline & Repeat(2) Business & Non/Repeat Business \\
\hline Awarded & 54 & 188 \\
& $(28.9 \%)$ & $(45.4 \%)$ \\
Non-Awarded & 133 & 226 \\
& $(71.1 \%)$ & $(54.6 \%)$ \\
Total Cases & 187 & 414 \\
\hline
\end{tabular}

219 The presence of a repeat business-arbitrator pair cannot explain the consumer's pro se status because the arbitrator would not be appointed until after the consumer filed the claim.

220 We used the second definition of repeat business because only for repeat businesses so defined did we find any evidence of a repeat-player effect.

221 The Pearson's Chi-squared statistic is 14.6401 (DF $=1$ and $p=0.000$ ), which allows us to reject the null hypothesis that whether a case is awarded is not associated with whether the respondent is a repeat (2) business. 
In short, while we find some indication of a repeat-player effect, the evidence seems to suggest that the repeat-player effect is more likely due to case screening by repeat businesses than arbitrator (or other) bias.

\section{CONCLUSIONS}

Our central empirical findings are as follows:

- Consumer claimants brought the substantial majority (approximately $86.0 \%$ ) of cases in the AAA consumer dataset from 2005 through 2007 . Of the cases brought by consumer claimants, $32.1 \%$ were resolved by an award, while in cases brought by business claimants, $49.9 \%$ were resolved by an award. The remaining cases typically were either settled or dismissed voluntarily by the parties.

- Overall, in the case file sample of consumer cases awarded from April 2007 through December 2007, consumer claimants were assessed an average of \$129 in AAA administrative fees and \$247 in arbitrator's fees. Consumer claimants seeking less than $\$ 10,000$ were assessed an average of $\$ 1$ in AAA administrative fees and $\$ 95$ in arbitrator's fees, while consumer claimants seeking between $\$ 10,000$ and $\$ 75,000$ were assessed an average of $\$ 15$ in AAA administrative fees and \$204 in arbitrator's fees. Consumer claimants seeking more than $\$ 75,000$ were assessed an average of $\$ 1448$ in administrative fees and $\$ 1256$ in arbitrator's fees. For cases subject to the AAA's low-cost consumer arbitration rules (i.e., with a claim amount of $\$ 75,000$ or less), consumers almost never paid more than the amount specified in the rules and often paid less - as a result of the arbitrator reallocating some portion of the consumer's share of costs to the business in the award.

- The average time from filing to final award for the AAA consumer arbitration cases in the case file sample was 207 days (6.9 months), subject to some possible degree of case selection bias. Cases with business claimants were resolved in 198 days (6.6 months) on average; cases with consumer claimants were resolved in 209 days (7.0 months) on average.

- Of the cases in the case file sample, consumer claimants won some relief in $53.3 \%$ of the cases (128 of 240 ) they brought. On average, successful consumer claimants were awarded $\$ 19,255$ in compensatory damages and recovered $52.1 \%$ of the amount they sought; the median amount awarded was $\$ 5000$ and the median percent recovery was $41.7 \%$. Business claimants won some relief in 
$83.6 \%$ of the cases (51 of 61) they brought. On average, successful business claimants were awarded $\$ 20,648$ and recovered $93.0 \%$ of the amount they sought; the median amount awarded was $\$ 11,110$ and the median percent recovery was $100.0 \%$. We cannot evaluate whether these recoveries are favorable or unfavorable for consumers.

- Consumer claimants sought to recover attorneys' fees in sixty-five of the 128 cases in which they were awarded damages. In forty-one of those sixty-five cases (or 63.1\%), the arbitrator awarded attorneys' fees to the consumer. In those cases in which the award of attorneys' fees specified a dollar amount ( 35 cases), the average attorneys' fee award was $\$ 14,574$ and the median award was $\$ 9000$.

- Under the usual definition of a repeat business, we find no statistically significant repeat-player effect: consumer claimants won some relief in $51.8 \%$ of cases against repeat businesses so defined and $55.3 \%$ of cases against non-repeat businesses, a difference that is not statistically significant. Under an alternative definition of a repeat business, based on the AAA's categorization of businesses in enforcing compliance with the Consumer Due Process Protocol, we find some evidence of a repeat-player effect as to win rate (claimants won some relief in $43.4 \%$ of cases against repeat businesses and $56.1 \%$ of cases against non-repeat businesses, a difference that is weakly statistically significant) but not as to the percentage of claim amount recovered by consumer claimants (claimants actually were awarded a higher percentage of the amount claimed against repeat businesses than against non-repeat businesses). But the evidence suggests that any repeat-player effect is not due to arbitrator (or other) bias in favor of repeat businesses. Instead, it appears to result from case screening by repeat businesses, with those businesses resolving consumer claims prior to an award at a much higher rate than non-repeat businesses.

An important implication of these findings is that not all consumer arbitrations are alike. In the case file sample of AAA consumer arbitrations, for example, the types of claims brought by consumer claimants differed from the types of claims brought by business claimants. Arbitration clauses in some types of contracts commonly included class arbitration waivers, while arbitration clauses in other types of contracts did not. Likewise, not all arbitration providers are alike. Some administer claims that are predominantly brought by businesses, while others have a higher proportion of claims brought by consumers. Policymakers should not assume that empirical findings for one type of consumer arbitration necessarily will be 
the same for other types. Nor should policymakers assume that empirical findings for arbitrations administered by one arbitration provider necessarily will be the same for arbitrations administered by other providers. Of course, the same holds true for the empirical findings in this article-that they do not necessarily hold for other types of arbitration or for other arbitration providers. These variations suggest the need for a nuanced approach to public policy concerning arbitration.

Despite the insights that empirical research can provide, it nonetheless has important limitations. First, our results are limited to AAA consumer arbitrations. Our data do not address arbitrations administered by other arbitration providers. Second, one must have a baseline for comparison to evaluate the cost, speed, and outcomes of consumer arbitrations; data on arbitration proceedings alone are not enough. Accordingly, this article's findings are only a beginning. While they provide a look into consumer arbitrations administered by the AAA, further work remains to be done. 


\section{APPENDIX 1. \\ EMPIRICAL STUDIES OF CONSUMER ARBITRATION}

This appendix lists the empirical studies of consumer arbitration discussed in the body of this Article. For each study, it describes the sample and summarizes the central findings of the study. It also briefly describes any criticisms of the study.

\section{A. AAA Consumer Arbitration}

1. AM. ARB. ASS'N, ANALYSIS OF THE AMERICAN ARBITRATION ASSOCIATION'S CONSUMER ARBITRATION CASELOAD: BASED ON CONSUMER CASES AWARDED BETWEEN JANUARY AND AUGUST 2007, available at $\mathrm{http}: / / \mathrm{www} \cdot a \mathrm{dr} .0 \mathrm{~g} / \mathrm{si}$.asp?id=5027.

Sample: 310 AAA cases resulting in an award from January 2007 through August 2007.222

Findings: $41 \%$ of the cases were decided on the basis of documents only, while $59 \%$ were resolved after a telephone or in-person hearing. Cases on average took about four months to resolve on the basis of documents and about six months to resolve on the basis of an in-person hearing. Consumer claimants won $48 \%$ of awarded cases they brought; business claimants won $74 \%$ of awarded cases they brought. 223

Criticisms: Public Citizen criticized the AAA's analysis on several grounds. First, it found the win rate calculated by the AAA to be "unreliable because any arbitrator award was counted as a win, regardless of its relation to the amount sought. This means, for example, that AAA would deem victorious a claimant who sought $\$ 50,000$ and received only $\$ 5$."224 Second, Public Citizen faulted the AAA because Public Citizen was unable to duplicate the AAA's findings from the AAA's public disclosures. ${ }^{225}$ Third, Public Citizen pointed out that business claimants had a higher win rate than consumer claimants. ${ }^{226}$

222 AAA, 2007 Caseload Analysis, supra note 35.

223 Id.

224 Public Citizen, ARbitration Debate TRAP, supra note 6, at 12.

225 Id. (" $[\mathrm{W}] \mathrm{e}$ could discern the victorious party only in approximately 7 percent of the cases. AAA left the 'prevailing party' field-a required disclosure-blank in more than 90 percent of the cases it has reported.").

${ }^{226} \mathrm{Id}$. 
2. Statement of the American Arbitration Association, Annex D, in The Arbitration Fairness Act of 2007: Hearing on S. 1782 Before the Constitution Subcomm. of the Senate Comm. on the Judiciary, 110th Cong. 135 (2007)

Sample: 987 cases brought by consumer claimants before the AAA that were resolved in $2006 .{ }^{227}$

Findings: The AAA reported that $42 \%$ of the cases were resolved by an award, while $58 \%$ were resolved prior to an award. The consumer was awarded some monetary relief in $48 \%$ of the cases resolved by an award. Cases awarded on the basis of documents (34\% of all awarded cases) took on average 3.8 months to resolve; cases awarded following an in-person hearing (66\% of all awarded cases) took on average 7.4 months. ${ }^{228}$

3. ERNST \& YOUNG, OUTCOMES OF ARBITRATION: AN EMPIRICAL STUDY OF CONSUMER LENDING CASES 16, App. A (2004), available at http://www.adrforum.com/rcontrol/documents/ResearchStudiesAndStatistics/ 2005ErnstAndYoung.pdf.

Sample: As part of its study of NAF arbitrations described below, 229 Ernst \& Young examined forty-four AAA consumer cases classified as involving "banking" disputes. The cases were among those included on the AAA web site as part of its required disclosures under California law. ${ }^{230}$

Findings: Ernst \& Young reported that: (1) the average amount claimed was $\$ 81,371$; (2) the average fee paid (in the 31 cases for which such information was available) was $\$ 1935$; (3) $50 \%$ of the cases settled, $11 \%$ were withdrawn by the claimant, and in the remaining $39 \%$ the arbitrator issued a decision; and (4) no information was provided for the amount awarded and rarely was the prevailing party identified. ${ }^{231}$

\section{B. Other Consumer Arbitration}

1. Memorandum from Jeff Nielsen et al. re: National Arbitration Forum: California Consumer Arbitration Data 3 (July 18, 2003), available at http://www.instituteforlegalreform.com/get_ilr_doc.php?docId=1212.

\footnotetext{
227 AAA, 2006 Caseload Analysis, supra note 36, at 135.

228 Id.

229 See infra text accompanying notes 251-59.

230 ERNST \& YounG, supra note 27, at 16, App. A.

231 Id.
} 
Sample: Same as in Public Citizen, The Arbitration Trap (see study no. 2 , below). ${ }^{232}$

Findings: Of the 33,948 total NAF arbitrations, 26,665 were either heard by an arbitrator or dismissed (the excluded cases were settlements). Navigant concluded that "[o]f these 26,665 arbitrations, consumer parties were reported to have prevailed outright or had the case against them dismissed in 8558 cases $(32.1 \%)$. Claims against consumers were reduced by NAF in an additional 4376 cases (16.4\%)." 233 According to Navigant, "the median reduction was $\$ 636$ and the median percentage reduction was $8.6 \% .{ }^{.234}$ Of the 33,935 cases in which an arbitration fee was paid, the consumer paid no fee in 33,689 cases $(99.3 \%)$. In the remaining 246 cases, the median fee paid by the consumer was $\$ 75.235$

Criticisms: Public Citizen criticized the Navigant report on several grounds. First, the vast majority ( 8534 of 8558 , or $99.6 \%$ ) of the cases that Navigant treated as cases in which the consumer prevailed were dismissals, rather than awards. And of the dismissals, almost all (7783, or $91.2 \%$ ) occurred before an arbitrator was appointed. According to Public Citizen: "These cases can hardly be used as evidence of the fairness of NAF arbitration. They scarcely involved arbitration at all."236 Second, the 700 dismissals after appointment of an arbitrator, according to Public Citizen, might have occurred "for any number of manipulative reasons," such that "it is possible that the consumers who 'won' the cases... lost the very same cases later."237

2. John O'Donnell, et Al., Public Citizen, The Arbitration TraP: How CREDIT CARD COMPANIES ENSNARE CONSUMERS 1 (Sept. 2007), available at $\mathrm{http} / / / \mathrm{www} . \mathrm{citizen.org/documents/ArbitrationTrap.pdf.}$

Sample: Relying on the National Arbitration Forum's California disclosures (which it reformatted into an Excel spreadsheet ${ }^{238}$ ), Public

232 Nielsen et al., supra note 26, at 1 ; see infra text accompanying notes $238-45$.

233 Nielsen et al., supra note 26 , at 1 .

234 Id. at 3.

235 Id.

236 Public Citizen, ARBitration Debate TraP, supra note 6, at 10.

237 Id. at 11.

238 See Public Citizen, NAF California Data Jan. 2003 to Mar. 2007, available at http://www.citizen.org/congress/civjus/arbitration/NAFCalifornia.xls. For a statistical analysis of the Public Citizen data, see Joshua M. FranK, CTR. FOR RESPONSIBLE 
Citizen analyzed outcomes in 33,948 NAF consumer arbitrations between January 1, 2003 and March 31, 2007. The vast majority of cases were filed by businesses against consumers; only $118(0.35 \%$ of the cases) were brought by consumers against businesses. 239

Findings: In the cases with consumer claimants, businesses prevailed in sixty-one cases and consumers in thirty cases; in the remaining cases the prevailing party was listed as "N/A." In 14,654 cases, no arbitrator was ever appointed and the case was either settled or dismissed. In the 19,294 cases in which an arbitrator was appointed, the business won in 18,091 (or 93.8\%)most of which were resolved on the basis of documents only with the consumer not appearing - while the consumer won in 781 (4.0\%). 240 Public Citizen also provided information on the arbitrators who decided the cases: twenty-eight arbitrators decided $89.5 \%$ of the cases in which an arbitrator was appointed, with the busiest according to Public Citizen deciding sixtyeight cases in a single day. 241

Criticisms: Professor Peter B. Rutledge criticized Public Citizen's data analysis on several grounds. First, the focus of the report was narrow, addressing a single arbitration provider (NAF) and a single type of business (consumer credit). ${ }^{242}$ Second, the high win rate for businesses was due to the type of claim involved - debt collection actions - which tend to have "very little to dispute." $243 \mathrm{He}$ notes: "Studies of debt collection actions in major cities reveal that the lender typically wins between $96 \%$ and $99 \%$ of the time, right in line with the lender win rate data cited in the Public Citizen Report." 244 Rutledge also states that Public Citizen misinterpreted the NAF data in estimating the number of cases decided by arbitrators in a single day. ${ }^{245}$

Lending, Stacked Deck: A Statistical Analysis of Forced Arbitration (May 2009), available at http://www.responsiblelending.org/credit-cards/researchanalysis/stacked_deck.pdf.

239 Public Citizen, Arbitration TRAP, supra note 6, at 15.

240 Id.

241 Id. at 16.

242 RUTLEDGE, GOOD DEAL, supra note 6, at 10.

243 Id. at 11 .

244 Id.

245 Id. at 11-12 ("This argument mischaracterizes the California data. Those data include a field for the date of the award. The Public Citizen Report treats this listed date as the day when the arbitrator actually rendered an award. This is incorrect. Rather, the California data reflect the date that the award was entered into NAF's system. An arbitrator may render a series of awards over several days, yet NAF enters those awards 
3. Mark Fellows, The Same Result as in Court, More Efficiently: Comparing Arbitration and Court Litigation Outcomes, METRO. CORP. COUNSEL, July 2006, at 32.

Sample: Mark Fellows of the National Arbitration Forum reported information about NAF arbitrations from 2003-2004. The data was compiled from disclosures made by NAF as required by California law. 246

Findings: Fellows found that consumer claimants "prevail in $65.5 \%$ of cases that reach a decision," while business claimants "prevail in $77.7 \%$ of cases that reach a decision." The time from filing until disposition averaged 4.35 months for consumer claimants and 5.60 months for business claimants. On average, consumer claimants paid $\$ 46.63$ in arbitration fees while business claimants paid $\$ 149.50$ in arbitration fees. ${ }^{247}$

Criticisms: Public Citizen criticized Fellows' analysis on several grounds. First, Fellows treats a business withdrawing a claim as a win for the consumer. But " $[t]$ hese claims are not comparable to judicial decisions after bench trials. ${ }^{248}$ When only cases decided by an arbitrator are considered, businesses prevail at a much higher rate. Second, Public Citizen was not able to duplicate Fellows' estimate of consumer claimants' win rates, finding instead that "consumers prevailed in only 37.2 percent of consumer-initiated cases that reached a decision."249 Regardless, cases with consumer claimants "account for a miniscule percentage of NAF arbitrations and therefore are not representative of NAF arbitrations." 250

into its system in a single day.").

246 Fellows, supra note 25 , at 32.

247 Id.

248 Public Citizen, Arbitration Debate Trap, supra note 6, at 9.

249 Id. at 10.

250 Id. 
4. ERNST \& YOUNG, OUTCOMES OF ARBITRATION: AN EMPIRICAL STUDY OF CONSUMER LENDING CASES 16, App. A (2004), available at http://www.adrforum.com/rcontrol/documents/ResearchStudiesAndStatistics/ 2005EmstAndYoung.pdf. 251

Sample: 226 NAF arbitrations brought by consumers between January 2000 and January 2004..$^{252}$ The study did not include information on arbitrations brought by businesses.

Findings: The largest category of disputes involved credit card fees and charges $(38.9 \%$ of the cases), with other significant case types including disputes over credit card chargebacks $(8.4 \%)$, mortgage loans $(8.4 \%)$, and other loans (7.5\%). ${ }^{253}$ The substantial majority of claims $(73.0 \%)$ sought $\$ 15,000$ or less; only $7.0 \%$ of claims were for more than $\$ 75,000 .{ }^{254}$ Overall, 129 of the 226 cases (or $57.1 \%$ ) were dismissed before hearing, either due to settlement or on request of the plaintiff. Ernst \& Young classified all but four of those cases as cases in which the consumer prevailed. ${ }^{255}$ Of the cases that reached a decision by the arbitrator, the consumer prevailed in fifty-three out of ninety-seven cases (or 54.6\%).256 Ernst and Young concluded: "Consumers appear to be satisfied with settlements accomplished prior to hearings and if a hearing takes place, consumers are not losing a disproportionate number of cases. Therefore, the findings from this analysis do not support claims that the arbitration process is harmful to consumers."257

251 See also supra text accompanying notes 229-31.

252 ERNST \& YOUNG, supra note 27 , at 7 . Of the 250 casefiles provided by the NAF, Ernst \& Young excluded 24 employment-related cases from the study. Id. at 7.

253 Id. at 8.

254 Id.

255 Id. at 9 ("Under the first measure, a claimant is said to prevail if the arbitration decision favored the claimant, or if the case was dismissed at the claimant's request or per party agreement. This measure assumes that the consumer was sufficiently satisfied with the settlement to dismiss the arbitration proceedings."). The four dismissals in which the consumer did not prevail, according to Ernst \& Young, were ones in which either the NAF dismissed the case due to some deficiency or the consumer dismissed the case because he or she could not afford to continue. Id. at 9 n.11.

256 Id. at 9.

257 Id. at 10. In addition to its case analysis, Emst \& Young surveyed twenty-nine of the consumers involved in the cases (twenty-five of whom had prevailed in their cases). Of those responding, twenty-five (or $69 \%$ ) either "were satisfied or very satisfied with the arbitration process." Id. at 11-12. 
Criticisms: Bland et al. have criticized the Ernst \& Young study on several grounds. ${ }^{258}$ First, the study examined only the arbitration process and did not compare arbitration to litigation. Second, the study included dismissals, whether by claimant request or party agreement, as wins by the claimant. It also included any case in which a claimant prevailed, regardless of the amount recovered, as a win. Third, the study focused only on the claims filed by consumers, "disregarding more than 100,000 filed by corporations against consumers during the same four-year period." 259

5. CAL. DISP. RESOl. INST., CONSUMER AND EMPLOYMENT ARbitration IN California: A Review of Website Data Posted Pursuant to Section 1281.96 of the Code Of Civil Procedure (Aug.

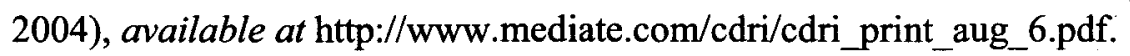

Sample: 2175 arbitration cases from January 2003 through February 2004, posted on websites of six different arbitration providers as required by California law. The six providers were the AAA, ADR Services, Arbitration Works, ARC Consumer Arbitrations, JAMS, and Judicate West. ${ }^{260}$ Although the study included data on both consumer and employment arbitration, the reported results did not distinguish between the two. ${ }^{261}$

Findings: The CDRI prefaced its findings with the statement that "[i]n general, inconsistencies, ambiguities and the lack of reported data in some areas limit this study's utility for the purposes of informing policy."262 Data on both filing and disposition dates were available for 1559 cases. For those cases, the mean disposition time was 116 days, while the median was 104 days. ${ }^{263}$ The amount of arbitrator's fee was available for 1404 cases; the mean fee was $\$ 2256$ while the median fee was $\$ 870 .{ }^{264}$ The prevailing party was identified for 302 cases. The consumer prevailed in 215 (or $71.2 \%$ ) of those cases, while the business prevailed in the remaining eighty-seven cases

258 F. PAUL BLAND JR. ET AL., CONSUMER ARBITRATION AgrEEMENTS: ENFORCEABILITY AND OTHER TOPICS 11 (5th ed. 2007); see also PUBlic Citizen, ARBITRATION TRAP, supra note 6, at 20.

259 BLAND ET AL., supra note 258, at 11.

260 CALIFORNIA DiSPUTE RESOlUTION INST., supra note 28, at 14.

261 Id. at 22 fig. 1 .

262 Id. at 18. For a detailed description of the problems, see id. at 27-32.

$263 \mathrm{Id}$. at 19.

264 Id. at 21 . 
(or $28.8 \%$ ). ${ }^{265}$ The amount of the award was reported for 540 cases; the mean amount awarded was $\$ 33,112$ while the median amount awarded was $\$ 7615.266$

Criticisms: Bland et al. identified the following criticisms of these results. First, as the CDRI itself recognized, the data it was reviewing were too incomplete to reach any firm conclusions. ${ }^{267}$ Second, the study "appears to exclude collection actions brought by creditors against consumers and any arbitrations from the National Arbitration Forum, a lightning rod concerning the fairness of consumer arbitration." 268

6. Answers and Objections of First USA Bank, N.A. to Plaintiff's Second Set of Interrogatories, Ex. 1, Bownes v. First U.S.A. Bank, N.A. Civ. Action No. 99-2479-PR (Ala. Circuit Ct. 2000), available at http://www.publicjustice.net/Repository/Files/McQuillanExhibit_16-19.pdf.

Sample: Data on NAF arbitration outcomes between 1998 and 2000, produced by First USA Bank in response to interrogatories in an Alabama lawsuit. ${ }^{269}$

Findings: The data showed that of the 51,622 NAF arbitrations in which First USA was involved with consumers, it prevailed in 19,618 while the cardholder prevailed in eighty-seven. Of the cases in which First USA prevailed, the substantial majority $(17,293$ of 19,618 , or $88.1 \%)$ were cases in which the consumer did not respond. Another 28,248 cases expired, typically for failure to serve the cardholder within ninety days, and another 3666 were pending at the time the discovery response was made. Consumers brought four cases against First USA, prevailing in two of the cases and settling a third; the fourth was still pending. ${ }^{270}$ These results are commonly cited as showing that "First USA prevailed in an astonishing 99.6 percent of cases." 271

Criticisms: The NAF responded that collection cases in court have a similar success rate for businesses ("creditors win about 98 percent of

265 Id. at 25.

$266 \mathrm{Id}$. at 20.

${ }^{267}$ BLAND ET AL., supra note 258, at 12 ; see also PUBLIC CITIZEN, ARBITRATION DEBATE TRAP, supra note 6, at 11-12.

268 BLAND ET AL., supra note 258, at 12.

269 First USA Interrogatory Answers, supra note 54, ex.1.

270 Id. at 38 , ex. 1.

271 PUblic CitIZEN, ARBITRATION TRAP, supra note 6, at 13. 
collection actions brought against debtors in federal courts") and that " "expired' cases should be counted as victories for consumers." 272

272 Caroline E. Mayer, Win Some, Lose Rarely? Arbitration Forum's Rulings Called One-Sided, WASH. POST, Mar. 1, 2000, at E01 (quoting Ed Anderson, NAF managing director). 


\section{APPENDIX 2.}

EMPIRICAL STUDIES OF EMPLOYMENT ARBITRATION AND SECURITIES

\section{ARBITRATION}

This appendix lists empirical studies of employment and securities arbitration, organized by type of arbitration and author name.

\section{A. Employment Arbitration}

Lisa B. Bingham \& Shimon Sarraf, Employment Arbitration Before and After the Due Process Protocol for Mediation and Arbitration of Statutory Disputes Arising Out of Employment: Preliminary Evidence that SelfRegulation Makes a Difference, in ALTERNATE DISPUTE RESOLUTION IN THE EMPLOYMENT ARENA: PROCEEDINGS OF THE NEW YORK UNIVERSITY 53rd ANNUAL CONFERENCE ON LABOR 303 (Samuel Estreicher \& David Sherwyn eds., 2004).

Lisa B. Bingham, Self-Determination in Dispute System Design and Employment Arbitration, 56 U. MIAMI L. REV. 873 (2002).

Lisa B. Bingham, Unequal Bargaining Power: An Alternative Account for the Repeat Player Effect in Employment Arbitration, IRRA 50th ANN. PROC. 33 (1998).

Lisa B. Bingham, On Repeat Players, Adhesive Contracts, and the Use of Statistics in Judicial Review of Arbitration Awards, 29 MCGEORGE L. REV. 223 (1998).

Lisa B. Bingham, An Overview of Employment Arbitration in the United States: Law, Public Policy and Data, N.Z. J. INDUS. REL., June 1998, at 5.

Lisa B. Bingham, Employment Arbitration: The Repeat Player Effect, 1 EMP. RTS. \& EMP. POL'Y J. 189 (1997).

Lisa B. Bingham, Emerging Due Process Concerns in Employment Arbitration: A Look at Actual Cases, 47 LAB. L.J. 108 (1996).

Lisa B. Bingham, Is There a Bias in Arbitration of Non-Union Employment Disputes?, 6 INT'L J. CONFLICT MGMT. 369 (1995). 


\section{AN EMPIRICAL STUDY OF AAA CONSUMER ARBITRATIONS}

Alexander J.S. Colvin, Empirical Research on Employment Arbitration: Clarity Amidst the Sound and Fury?, 11 EMP. RTS. \& EMP. POL'Y J. 405 (2007).

Alexander J.S. Colvin, Paper Presentation at 62nd Annual Conference on Labor, New York University, Employment and Consumer Arbitration: What Do the Data Show? (June 5, 2009).

Michael Delikat \& Morris M. Kleiner, An Empirical Study of Dispute Resolution Mechanisms: Where Do Plaintiffs Better Vindicate Their Rights?, DISP. RESOL. J., Nov. 2003/Jan. 2004, at 56.

Theodore Eisenberg \& Elizabeth Hill, Arbitration and Litigation of Employment Claims: An Empirical Comparison, DISP. RESOL. J., Nov. 2003/Jan. 2004, at 44.

Samuel Estreicher, Saturns for Rickshaws: The Stakes in the Debate over Predispute Employment Arbitration Agreements, 16 OHIO ST. J. ON DISP. RESOL. 559 (2001).

Elizabeth Hill, Due Process at Low Cost: An Empirical Study of Employment Arbitration Under the Auspices of the American Arbitration Association, 18 OHIO ST. J. ON DISP. RESOL. 777 (2003).

Elizabeth Hill, AAA Employment Arbitration: A Fair Forum at Low Cost, DISP. RESOL. J., May/July 2003, at 9.

William M. Howard, Mandatory Arbitration of Employment Disputes: What Really Does Happen? What Really Should Happen?, DiSP. RESOL. J., Oct./Dec. 1995, at 40..

William M. Howard, Mandatory Arbitration of Employment Arbitration Disputes: Can Justice Be Served? (May 1995) (unpublished Ph.D. dissertation, Arizona State University).

Lewis L. Maltby, Employment Arbitration and Workplace Justice, 38 U.S.F. L. REV. 105 (2003).

Lewis L. Maltby, The Myth of Second-Class Justice: Resolving Employment Disputes in Arbitration, in How ADR WoRKS 915 (Norman Brand ed., 2002). 
Lewis L. Maltby, Arbitrating Employment Disputes: The Promise and the Peril, in ARBITRATION OF EMPLOYMENT Disputes 530 (Daniel P. O'Meara ed., 2002).

Lewis L. Maltby, Private Justice: Employment Arbitration and Civil Rights, 30 COLUM. HUM. RTS. L. REV. 29 (1998).

NATIONAL WORKRIGHTS INST., EMPLOYMENT ARBITRATION: WHAT DOES THE DATA SHOW?, available at http://www.workrights.org/current/cd_arbitration.html.

HOYT N. WHEELER, WORKPLACE JUSTICE Without UNIONS 47-68 (2004).

\section{B. Securities Arbitration}

Stephen B. Choi, Jill E. Fisch, \& A.C. Pritchard, Attorneys as Arbitrators (Nov. 2008), available at http://www.law.northwestern.edu/searlecenter /papers/Choi_attorneys_final.pdf.

General AcCounting Office, How InVestors Fare, Rep. No. GAO/GGD-92-74 (May 1992).

General AcCounting Office, Securities Arbitration: ACtions NEEDED to AdDREsS PRoblem OF UNPAID AWARDS, Rep. No. GAO/GGD/00-115 (June 2000).

Jiro E. Kondo, SELF-RegUlation and ENFORCEMENT IN FinANCIAL MARKETS: EVIDENCE FROM INVESTOR-BROKER DISPUTES AT THE NASD (Dec. 25, 2007).

Edward S. O'Neal \& Daniel R. Solin, Securities Litig.\& CONSULTING GROUP, MANDATORY ARBITRATION OF SECURITIES DISPUTES: A STATISTICAL ANALYSIS OF HOW CLAIMANTS FARE (2007), available at http://www.slcg.com/pdf/news/Mandatory\%20Arbitration\%20Study.pdf.

Michael A. Perino, Report to the Securities and Exchange Commission Regarding Arbitrator Conflict Disclosure Requirements, in NASD AND NYSE SECURITIES ARBITRATIONS 32-33 (Nov. 4, 2002). 